Frontier Justice: Colonial Governmentalities and 19th Century "Law and Order" in the North-West.

$$
\text { by }
$$

Jeffrey Monaghan

\begin{abstract}
A thesis submitted to the Faculty of Graduate and Postdoctoral Affairs in partial fulfillment of the requirements for the degree of
\end{abstract}

Master of Arts

in

Legal Studies

Carleton University

Ottawa, Ontario

(C) 2011

Jeffrey Monaghan 
Library and Archives Canada

Published Heritage Branch

395 Wellington Street Ottawa ON K1A ON4 Canada
Bibliothèque et

Archives Canada

Direction du

Patrimoine de l'édition

395, rue Wellington

Ottawa ON K1A ON4

Canada
Your file Votre référence

ISBN: 978-0-494-81638-7

Our file Notre référence

ISBN: 978-0-494-81638-7
NOTICE:

The author has granted a nonexclusive license allowing Library and Archives Canada to reproduce, publish, archive, preserve, conserve, communicate to the public by telecommunication or on the Internet, loan, distribute and sell theses worldwide, for commercial or noncommercial purposes, in microform, paper, electronic and/or any other formats.

The author retains copyright ownership and moral rights in this thesis. Neither the thesis nor substantial extracts from it may be printed or otherwise reproduced without the author's permission.
AVIS:

L'auteur a accordé une licence non exclusive permettant à la Bibliothèque et Archives Canada de reproduire, publier, archiver, sauvegarder, conserver, transmettre au public par télécommunication ou par l'Internet, prêter, distribuer et vendre des thèses partout dans le monde, à des fins commerciales ou autres, sur support microforme, papier, électronique et/ou autres formats.

L'auteur conserve la propriété du droit d'auteur et des droits moraux qui protège cette thèse. $\mathrm{Ni}$ la thèse ni des extraits substantiels de celle-ci ne doivent être imprimés ou autrement reproduits sans son autorisation.
In compliance with the Canadian Privacy Act some supporting forms may have been removed from this thesis.

While these forms may be included in the document page count, their removal does not represent any loss of content from the thesis.
Conformément à la loi canadienne sur la protection de la vie privée, quelques formulaires secondaires ont été enlevés de cette thèse.

Bien que ces formulaires aient inclus dans la pagination, il n'y aura aucun contenu manquant. 


\begin{abstract}
I define "frontier justice" as the ordering of frontier according to the normative values of settler colonialism. Detailing materials surrounding the 1885 North-West Rebellion, I examine "colonial governmentalities" that shaped early colonial strategies in Canada's North-West Territories. Developing on ideas of Foucault's, I argue that colonial governmentalities balance techniques of sovereign as well as biopolitical power in the process of ordering the frontier. In particular, this demonstrates how indigenous populations are incorporated by processes of state formation and categorized along a continuum of "good" and "bad" conduct. While the settlement of the Canadian prairies is often depicted through myths of "empty origins" or as a "bloodless revolution," the transformation of the North-West was replete with violence and injustice. Reviewing archival records helps interrogate practices at work in the North-West and, in revealing how frontier justice is not remote or historical, demonstrates the continuity of these rationalities in the colonial present.
\end{abstract}




\section{Table of Contents}

Chapter One: Conceptualizing Frontier Justice..................................... 1

Introduction

Frontiers, Sovereignty, Jurisdiction

Foucault, Populations, and the Apparatus of Security

Race/Racism, Colonial Governmentality, Normalizing Society

Why a "Canadian" Account of "Frontier Justice"?

Chapter Outline

Chapter Two: To Feed Them or Fight Them: Dangerousness, Internal Enemies, and Biopower......

The Frontier Context: Indian Policy in the Prairies, 1870-1885

Peter Ballendine: Surveillance and Dangerousness in the Frontier

The Craig Incident, 1884

To Feed Them or Fight Them: Discussion and Analysis

Chapter Three: Mounties in the Frontier: Circulations, Anxieties, Myths......... 76

The North-West Mounted Police and the 1885 Rebellion

Patrols and Lookouts

Otherness in the Frontier

Settler and Police Anxieties

Frontier Justice: NWMP Patrols, Law's Violence, and Mountie Myths

Conclusion: Frontier Justice: Past and Present

Frontier Justice and the Colonial Present

Bibliography. 


\section{Chapter One}

\section{Conceptualizing Frontier Justice}

"Under no circumstances should one pay attention to those who tell one: 'Don't criticize, since you're not capable of carrying out reform.' That's ministerial cabinet talk. Critique doesn't have to be the premise of a deduction which concludes: this then is what needs to be done. It should be an instrument for those who fight, those who resist what is. Its use should be in processes of conflict and confrontations, essays in refusal. It doesn't have to lay down the law for the law... It is a challenge to what is."

-Michel Foucault.'

\section{Introduction}

Accounts of Canadian history invariably valorize certain icons of Canadiana: the

peacekeeper, the pioneer, the Mountie. Self-congratulory and ubiquitous, these narratives represent the "foundational fictions" - in the words of Doris Sommer (1991) - of

Canada's colonial imaginary. Dominant accounts of Canadian identity reflect histories that celebrate open and unclaimed nature, the "discovery" of land, pioneering spirits, or the romantic coexistence of les coureurs des bois (Francis, 1997). Legal and historical professions in particular have incorporated foundational fictions as the basis of their institutional cultures (Knafla, 2005). Unfortunately, however, legacies of inequality and injustice that stem from Canada's practices of settler colonialism are rarely addressed. Although a healthy critical scholarship contrasts mythologies of Canadiana with less celebratory histories of European settlement/conquest, these critical portrayals often do not enter dominant representations of Canadian identity. This study contributes to vital efforts that grapple with the unfolding implications of settler society, presenting an alternative to the dominant imagination of Canada as a country that, in the words of Prime Minister Stephen Harper, has "no history of colonialism."2

\footnotetext{
${ }^{1}$ Foucault, $1991 \mathrm{~b}: 84$.

${ }^{2}$ Prime Minister Harper made these comments during a news conference at G20 meetings in Pittsburgh, USA, in September, 2009. While detailing Canadian virtues he said: "We also have no history of colonialism. So we have all of the things that many people admire about the great powers but none of the
} 
Contributing to the field of "colonial governmentalities" (Scott, 1995; 1999; $2005),{ }^{3}$ my research presents a particular way to interpret colonial policies of conquest. I focus on various strategies and instrumentalities - through the ideas of Michael Foucault that were deployed in domesticating the Western frontiers in Canada. ${ }^{4}$ Looking specifically at the period of time immediately surrounding the North-West Rebellion of 1885 , I examine archival records that speak directly to the emergence of particular practices of colonial power that unfolded within this unique period of time and space. Within the framework of "Frontier Justice" outlined herein, I examine colonial programs that target indigenous people as a particular subject-population to be imagined, disciplined, rewarded, governed. Moreover, I treat conquest as a process of normalization: where colonialism establishes the norms of settler society. Subsequently, expressions of indigeneity - culture, language, self-determination, i.e. behaviours and practices - are perceived as dangers or "internal enemies" (Foucault, 2003) to the prosperity of the settler state. These dangers and abnormalities are then targetted by processes of ordering and neutralization.

Canada's newly formed North-West Territories are an ideal site to explore processes of ordering and state formation. The North-West Rebellion was an armed uprising that spread across Manitoba and the North-West in the spring and summer of

things that threaten or bother them." The comments were widely reported and, subsequently, indigenous leaders demanded an apology from the Prime Minister. Harper offered no apology.

${ }^{3}$ Scott (1995) was an article that appeared in the journal Social Text. The article was slightly refined to become the introduction of his 1999 book Refashioning Futures: Criticism after Postcoloniality. That introduction was subsequently reprinted in Inda (2005). Throughout this thesis I cite primarily from his work presented first in the Social Text article (1995).

${ }^{4}$ Scott $(1995 ; 1999 ; 2005)$ cued the term "colonial governmentality", which has produced a very small literature (see Dutton, 2010; Ibrahim, 1997; Kalpagam, 2002; Kalpagam, 2000; Legg, 2005). This is particularly evident in contrast to the very broad post-Foucault "governmentality" literature (see Rose et al, 2006). Although my project adopts Scott's theoretical framework of "colonial governmentality," I prefer to use a plural "colonial governmentalities" in recognition of the complex and sometimes contradictory nature that animate strategies of rule. 
1885. It is associated mostly commonly with the unsuccessful declaration of an independent government led by Louis Riel (as well as Riel's subsequent execution). More broadly, I discuss the Rebellion, as well as the Canadian government's manipulative response, as the culmination of a 15-year effort, largely under Prime Minister John A. Macdonald's National Policy, to transform the vast territories of Rupert's Land into the settler dominion of Canada and suppress Indian subjects who were perceived as a danger to the project of settler colonialism. ${ }^{5}$

The period from 1870 to the 1885 Rebellion demonstrates a transformation in the rationalities of colonial governance in the pan-Canadian territories. Moving beyond objectives associated with the accumulation and fortification of territory, governmental rationalities soon emerged with the aim to regulate the conduct and health of aggregate populations. This spatial-temporal context is characterized by its intense project of nation building. Having just been transferred from the Hudson's Bay Company, the lands that are now the provinces of Alberta, Saskatchewan and Manitoba were the objects of political and economic ambitions for many years before Confederation in 1867. They were sparsely populated areas, with a plurality of legal and sovereign authorities, and the newly constituted Canadian state had prepared an ambitious program to domesticate this frontier territory.

This particular moment presents an ideal subject to investigate the colonial strategies that formed, organized, reformed, and enforced the various economies of power

\footnotetext{
${ }^{5}$ Throughout this thesis I use the term "Indian." This term is used in order to accurately reflect the archival and political contexts under examination. While this intended to express the language and attitudes of historical actors, contemporary (and more politically correct) terms such as Aboriginal, Natives, and First Nations are also the products of colonial discourses (Alfred and Corntassel, 2005). For this reason, and when appropriate, I use the term "Indigenous" when I am not describing the perspectives, actions and/or attitudes of government. While this does not reflect the proper and particular names of nations in the NorthWest, it reflects a broader scope of communities subjected to global patterns of colonialism and land theft from Frenchman's Butte to Palestine.
} 
that aim to govern and order colonial spaces. "Colonial governmentalities" are the strategies that inform practices of rule in colonial spaces. In this context, they are the way in which Canadian authorities sought to domesticate the frontier. Borrowing from the works of Foucault, this thesis demonstrates that the distinguishing characteristic of "colonial governmentalities" requires a balancing of sovereign techniques of powerfocussed on punishment, surveillance, and the enforcement of an overarching authority of centralized power - and what Foucault calls biopolitical techniques, which focus on transforming conduct through training, habituation, and the rewards system of capitalism. While sovereign techniques of power are focussed on the body - particularly those of indigenous peoples' - biopolitical techniques are focussed on the population and the health, prosperity, and well-being of the aggregate. As I will explore below, colonial governmentalities are an amalgam of these techniques of power, based on various conceptions for increasing the overall securitization of territory and governed bodies.

David Scott $(1995 ; 1999 ; 2005)$ demonstrates that the fundamental element distinguishing colonial governmentalities from previous rationalities governing European expansion is the re-prioritization of colonial objectives. By moving beyond the primary objective of extracting wealth - as epitomized by the Hudson's Bay Company - towards new objectives of permanent settlement and development, new rationalities of rule emerge. Scott (1995:214) describes an emergent form of rule "directed at the conditions of social life rather than the producers of social wealth, in which power was now to operate in such a way as to produce not so much extractive-effects on colonial bodies as governing-effects on colonial conduct." Within this context, the Canadian government would deploy new regimes of power which concern themselves with the well-being and 
health of the aggregate population, and the overall prosperity of the nation. These are administered through new regimes of control, which include an array of techniques to reward, suppress, encourage, or dissuade the behaviours of internal populations. According to Scott (1995:212), what "colonial governmentality" is doing "is inscribing a new authoritative game of justice into the colonized space, one which the colonized could accept or resist, but to whose rules they would have to respond."

Events surrounding the Rebellion of 1885 serve to demonstrate the forms of response - including acceptance, resistance, and more complicated forms of negotiation and diplomacy - that accompanied the "new authoritative game of justice" into the NorthWest frontier. Through an examination of archival records, this thesis narrates these events through first-hand accounts from Canadian authorities. Immediately following Confederation, the Canadian government advocated the "opening of the West," and analysis of these archival materials demonstrates how colonial actors - from distant Ottawa, as well as agents on the ground in the North-West - implemented strategies to govern and cemented their capacities to rule. Therefore, these records reveal the rationalities of government, which express the objectives, motives, and authorities of the government - what Dean (2002) calls the "government of the state" - while they also reveal the techniques, anxieties, troubles, and actions that are undertaken to achieve these ends. Archival materials that I analyze detail the process of ordering the frontier in the North-West and provide a substantive articulation of what I present as the unfolding of frontier justice.

There are no existing definitions of "frontier justice." The term, however, is often 
referenced throughout dominant culture. ${ }^{6}$ It is used most often as a reference to isolated mostly retributive - acts of violence within unorganized, untamed spaces of wildness somewhere at the fringes of (or outside) civilized society. Obadele-Starks (2007:7) demonstrates that, in the United States, the "essence of the frontier" was to "defy authority and the mandates they attempted to impose." Moreover, "frontier justice" was the manner in which juries, judges, lawyers, and police developed their own rules and procedures to accommodate the slave trade and other vigilante expeditions of American frontierism (Obadele-Starks, 2007:46-74). Harris (1997) alludes to somewhat similar practices during the settlement of British Columbia, when colonial authorities and fur traders utilized strategies that rested upon the "politics of fear" to intimidate and attempt to control indigenous communities. He writes (1997:48) that "as far as possible, trader violence was to be public, a spectacle of power intended to impress and dissuade within a pervasive theatre of power in which Natives, like company servants, were audience and actors." Mavromichalis (1998) uses the term "frontier justice" to describe the 1895 tarring and feathering of James Donaldson in Lethbridge. Donaldson, a white man, was sleeping with another white man's wife, which who, upon learning of Donaldson and his wife's affair, committed suicide. Mavromichalis uses "frontier justice" in reference to both the mob attack on Donaldson and the widespread public support expressed for the acts of violent retribution. Acts of frontier justice often depict vigilante-style episodes and, as the under current of these descriptions, they are often presented at-odds with liberal conceptions of the rule of law: these acts are summary, excessive, and without appeal or

\footnotetext{
${ }^{6}$ Although there is no fixed definition of frontier justice, the term has been widely referenced in film and literature. For example, "Frontier Justice" was the name of an American Western-drama television series (1958-1961). The term has also been used frequently in academic literature to describe colonial events, see Baldwin (1987); Ghere and Morrison (2001); Kingseed (2002); Roberts (2005); West \& Carey (2006).
} 
judicious processes. In other words, they are representations of what legal order in liberal society considers lawlessness.

The objective of this thesis project is to radically rethink this common reference to frontier justice. Re-conceptualizing "frontier justice" is important for two reasons. First, by focussing beyond one-off actions, this study is intended to emphasize the structural program of violence resulting from colonial practices. While individual accounts of violence are important to document, my contention here is that the most violent aspect of colonial accumulation (and indigenous dispossession) have accrued through the program of conquest. Conceptualizing frontier justice as a transformative program of organized violence - what Comaroff (2001) calls lawfare - contributes to existing critical scholarship on colonial practices by highlighting the structural violence that accompanies liberal impositions of "law and order." Secondly, in contrast with the depiction of the frontier as the outlier of civilization that we seek protection against, I contend that frontiers are not spaces that we seek to buttress, but spaces that we seek to possess. Frontiers become objects precisely because colonial authorities desire to control them. North American land, for example, has been under the claimed sovereign ownership of European powers since the 1493 Papal Bull of Inter caetera (Williams, 1990) - far before any Europeans had set foot on most of these lands. Therefore, these are not spaces external to empire, but, by virtue of expansionary desires, they have been interpolated as internal spaces fit to be rationalized and domesticated according to the standards of European liberal society. Therefore frontier justice is not a moment, or single event, at the chaotic outer ridge of civilization: it is a project of expansion within colonial spaces, represented as an object-territory for the application of order. From the European mind's 
eye, it is a space to be rendered from lawless into lawful. This thesis will define frontier justice as the process of ordering the frontier.

\section{Frontiers, Sovereignty, Jurisdiction}

Conceptualizing frontiers as objects to be ordered is rooted in European legal and cultural expansionary impulses, particularly the legal framework of sovereignty that stems from the "doctrine of discovery" (Williams, 1990; Miller, R., 2006). Burrows (1999) has called these claims of ownership the "alchemy" of sovereignty. Despite the universality claimed by European sovereignty, it was several centuries into the colonial project before "law and order" would attempt to be consistently enforced beyond the enclaves, forts, and cities of European inhabitation. For several centuries, European law was mostly the force of military-style authority, which rarely passed through a juridical process associated with continental European order (Churchill, 1997). In these frontier spaces, in fact, indigenous cultures fostered heterogeneous realities that included a number of plural and diverse legal authorities, which functioned notwithstanding the shadow of European legal order (Hall, 2003; Monture-Angus, 1999). ${ }^{7}$ Despite having claimed sovereignty over these lands, European authorities were unable to exercise jurisdiction over the spaces or populations within these claimed boundaries. For most of its 200 year history, Rupert's Land balanced plural legal realities and, with notable exceptions, colonial traders did not actively intervene within the internal legal order of the many indigenous nations (McNeil, 1982; Nigol, 2005). Until 1870, there was a distinction between sovereign claims of authority and the jurisdictional practices of law.

\footnotetext{
${ }^{7}$ The history of legal and historical plurality has only recently been recognized by Canadian legal system, by the Supreme Court of Canada in Delgamuukw v The Queen (1997). Despite this recognition, the court ruled that the responsibility of Canadian law - Section 35 of the Constitution, in particular - was to "reconcile the prior presence of aboriginal peoples with the assertion of Crown sovereignty." See (Monture-Angus, 1999) for a detailed analysis of the Delgamuukw ruling and its legitimization of colonial relations.
} 
The sale of Rupert's Land to the Dominion of Canada in 1869 marks a particular moment when governmental authority in Ottawa imagined a new political reality, where jurisdiction would be expanded from coast to coast. Kobayashi notes (1995:62) how, in the $19^{\text {th }}$ century, the "national dream" was to create a nation that "stretched from the Atlantic to the Pacific, peopled coast-to-coast with sturdy settlers who would uphold the British empire." In order to secure the spaces claimed by European sovereignty, colonial authorities were faced with the question: how do we apply law in the North-West frontier? What emerges following the "land sale" from 1870 to the time surrounding the NorthWest Rebellion of 1885 is a colonial project that aims to reconcile this disjunction between sovereignty and jurisdiction.

In her text Settler Sovereignty, Lisa Ford (2010) demonstrates that the relationship between sovereignty, jurisdiction, and territory cannot be considered as co-existing by default, nor can they be explained as co-established regimes. Ford argues that, through various processes, sovereignty-jurisdiction-territory have been slowly ordered and aligned through colonial practices. As evidenced by case studies in the United States and Australia, it was not until the 1820 s and 1830 s that settler polities began to extend universalized legal jurisdictions across their claimed territories of sovereignty. This occurred only because settlers "imagined for the first time that it was necessary to shore up the legitimacy of settlement" (Ford, 2010:3). In Upper Canada, Walters (1996) demonstrates that British authorities only sought to apply practices of legal jurisdiction as late as the early $1820 \mathrm{~s}$. Before the capacity to universalize taw over its sovereign territories, earlier stages of British imperial jurisdiction were messy, shared and separated. While not explicitly addressing Canada, these characteristics of British colonialism are 
useful to outline as they form the basis of settler-Indian relations inherited by Canada post-Confederation (Bartlett, 1980; McNab, 1983). Much of the British colonial relationship with indigenous peoples in North America was defined and governed by the covenant chain (Hall, 2003). This alliance, encoded in the Two Row Wampum, affirmed autonomous and peaceful cohabitation, while regulating trade, war and diplomatic affairs between the British and the Haudenosaunee. Following the defeat of the French, Wampums were then established along similar principles with former French allies such as the Algonquin. During the British colonial experience in Rupert's Land, the Hudson's Bay Company was granted near-exclusive domain over these British-claimed lands. The text of the HBC Charter specified that the law of England applied to those in territories that did not live under the authority of other previously established nations in the region. ${ }^{8}$ The HBC enforced a code of laws that protected the properties, interests, and bodies of European subjects. However "the company" largely did not interfere with the internal regulation of indigenous societies (Knafla 2005; Nigol 2005). This legal plurality was upheld for some time by British and early Canadian courts, particular in the case of Connelly $\mathrm{v}$ Woolrich. ${ }^{9}$ In other words, its laws were spatially limited and existed within a complex interplay of legal pluralisms.

The North-West Rebellion marks an important shift away from this plurality. Even by contemporary standards, the 1885 Rebellion stands as one of the most politically tumultuous periods in Canadian history. It remains the most extensive domestic military

\footnotetext{
${ }^{8}$ See Oliver (1915) for the full text of the HBC Charter.

${ }^{9}$ See discussion on Connelly $\mathrm{v}$ Woolrich in Hall, 2003:408-415. The decision was caped by the assertion from Justice Samuel Cornwallis Monk, or the Lower Canada Superior Court in Montreal, that John Connelly did not "carry with him the common law of England to Red Rat in his knapsack."
} 
operation in Canada. ${ }^{10}$ However, despite the panic experienced in Eastern Canada, the Rebellion was hardly a military threat to Canada. As discussed in Chapter Two and Three, Canada's response to the Rebellion resulted more from political and economic interests than military concerns, as it offered a pragmatic opportunity to squash movements demanding Indian autonomy (Stonechild and Maiser, 1997). Actions of the government were animated by a desire to reconcile the sovereignty-jurisdictional divide, and the Rebellion provided a definitive opportunity to enforce the "new authoritative game of justice" (Scott, 1995:212) into the North-West. In fact, the post-Rebellion era is often cited - especially in celebratory histories of the North West Mounted Police - as the "end of the frontier West" (Beahen and Horrall, 1998; Turner, 1950). For this reason, the period surrounding the Rebellion is an ideal subject to analyze the development of strategies and technologies that form the "new rules" developed through colonial governmentalities.

Canadian authorities developed new mechanisms to domesticate the frontier that, as Foucault (2007:378) would describe, aim "to establish a sort of homeostasis (...) by achieving an overall equilibrium: the security of the whole with regard to its internal dangers." As an event, the Rebellion marks an important transition from classical formations of sovereignty towards new colonial rationalities of power focussed on regulation through strategies that guide conduct, discipline non-disciplinary actors, and advance mechanisms to produce and fashion subjects according to the new rationalities of liberal, Western, governance. As I will demonstrate the ordering of the North-West is

\footnotetext{
${ }^{10}$ It could be argued the 2010 Winter Olympics in Vancouver/Whistler and the $2010 \mathrm{G} 8 / \mathrm{G} 20$ meetings in Huntsville/Toronto represent larger military mobilizations by virtue of the sheer volume of troops deployed. These recent mobilizations, however, were not active combat engagements which makes them difficult - if not impossible - to compare.
} 
dependent on these colonial governmentalities and the deployment of "mechanisms of security" (Foucault, 2007) that target perceptions of dangerousness and threats to the prosperity of the population. While the Rebellion as an event-marker is somewhat artificial, because drifts in governmental rationalities into the pre-and-post Rebellion contexts, the legal strategies deployed over the period of time surrounding the Rebellion are particularly acute. They are very explicit, the political stakes were exceptionally high, and because of the radical social, economic, and political transformations, this time and space was particularly fertile ground for colonial governmentalities utilized to solidify jurisdiction and order the frontier.

\section{Foucault, Populations, and the Apparatus of Security}

Michel Foucault introduced the theoretical concepts of "governmentality" and "biopolitics" in the late 1970s. Subsequently, these concepts have been developed by a number of scholars (see Rose et al, 2006: Brockling et al, 2011). Taking Foucault's 197576 and 1977-78 lectures at the Collège de France - published in English as "Society Must be Defended" (2003) and Security, Territory, Population (2007) - as a starting point, I explore how concepts of governmentality and biopolitics assist in explaining colonial desires to domesticate the North-West and produce new techniques to achieve these ends. Foucault's work is ideal to help explain transformations that occurred in the North-West. The central claim developed by Foucault in these lectures highlights how new economies of power flourish through the participation and acquiescence of those who are ruled. To facilitate the acquiescence of the ruled, colonial strategies shifted; moving from classical notions of sovereignty towards more subtle technologies of rule. This was accompanied by a shift in the target of governmental power: from individual units to aggregate populations. Not simply concerned with the disciplinary measures focussed on the body, 
these new technologies of power focus on the management of populations.

Targeting on the level of population is the essential characteristic of what Foucault describes as biopolitical power. In the biopolitical field of power, Foucault (1991a:102) describes the emergence of the population as a "datum," a "field of intervention," and both the target and objective of governmental techniques. It is only through the emergence of the "problem of populations" that ruling authorities can extend from sovereign to biopolitical practices of power. Foucault $(2007: 104)$ writes that it is "thanks to the perception of the specific problems of the population... that it was possible to think, reflect, and calculate the problem of government outside the juridical framework of sovereignty." Foucault (2007:105) argues that the population appears "as the end and instrument of government rather than as the sovereign's strength." Biopolitics is a result of the "population" emerging as both an end and an instrument of government, where governmental rationalities and practices are informed by these aggregate concerns for health, prosperity, growth, and regulation.

However, a focus on the health and prosperity of the aggregate population does not preclude or displace practices of sovereign power. As detailed extensively in Chapter Two, new forms of rule in colonial spaces balance a combination of sovereign and biopolitical measures. Describing the new strategies of rule that form the basis of "governmentality" and "biopower," Foucault (2003:242) says biopower "does not exclude disciplinary technology but it does dovetail into it, integrate it, modify it to some extent, and above all, use it by sort of infiltrating it, embedding itself in existing disciplinary techniques." Biopolitics does not do away with sovereign or disciplinary measures, but "operates at a different level, on a different scale... because it has a 
different bearing area, and makes use of very different instruments" (2003:242).

In his lectures on Security, Territory, Population, Foucault concludes the lecture known as the "governmentality lecture" (see Foucault, 1991a) by re-stating this relationship as a triangle, where sovereignty and discipline are in mutual interaction with each other and the new powers outlined as the "art of government." He states:

We need to see things not in terms of the replacement of a society of sovereignty by a disciplinary society and the subsequent replacement of a disciplinary society by a society of government; in reality one has a triangle, sovereignty-disciplinegovernment, which has as its primary target the population and as its essential mechanism the apparatus of security... The ensemble formed by the institutions, procedures, analyses and reflections, the calculations and tactics that allow the exercise of this very specific albeit complex form of power, which has as its target population, as its principal form of knowledge political economy, and as its essential technical means apparatuses of security (Foucault, 1991a:102; different translation: 2007:144).

Emerging from the eighteenth century, Foucault contends that new rationalities of government produce complex apparatuses and savoirs whereby the administration of the state becomes 'governmentalized.' Unlike centralized power of a unitary state, Foucault describes that the governmentalized state operates simultaneous and paradoxical powers. While the governmentalized state produces a widespread dispersal of authorities, these new powers are unified and enhanced through the primary attention to "the population" as a site for the practice of government. This does not do away with the individualizing tactics of sovereign or disciplinary practices, but presents an extension of these forms of power. Foucault (2003: 243) writes that "after a first seizure of power over the body in an individualizing mode, we have a second seizure of power that is not individualizing but, if you like, massifying, that is directed not at man-as-body but at man-as-species." As a massifying tendency, the art of government centres on the population as an aggregate; which must be regulated through decentralized mechanisms to promote prosperity and 
development.

Here, Foucault identifies the target of governmentalities as the population. Moreover, in the passage from the governmentality lecture cited at length above, he underlined the mechanism of intervention as the apparatus of security. Foucault describes what he calls "mechanisms of security" in the lecture series Security, Territory, Population, however they have a clear continuity to his early lectures (2003). In addition to sovereign or disciplinary measures that aim to repress or physically intervene upon targeted subjects, mechanisms of security employ these forms of punishments as well as systems of reward. Typically, Foucault had described disciplinary measures as individualizing, where subjects are targeted by particular techniques to re-align modes of subjectivity. Discipline rules a multiplicity of men, writes Foucault (2003:242), "to the extent that their multiplicity can and must be dissolved into individual bodies that can be kept under surveillance, trained, used, and, if need be, punished." Likewise, sovereign expressions of power target individuals with authoritative, repressive, and even exceptional, practices of rule. Mechanisms of security, however, are more elaborate. As interventions they aim to encourage and amplify the health of the population by taking control over "life and the biological process of man-as-species and of ensuring that they are not disciplined but regularized" (Foucault, 2003:247). This includes a vast array of interventions and, while they include sovereign and disciplinary techniques of punishment, they aim to promote new forms of conduct and the regulation of free exchanges.

Foucault characterizes this transformation in the rationalities of rule - a shift from classical conceptions of sovereign and disciplinary objectives to new forms of biopolitical 
regulation - as the power of the state over life. However, he explains that where the right of sovereignty was the right to "take life or let live," biopolitical right is the right to "make live and let die." Foucault (2003:247) stresses that the continuous and scientific "power of regulation" consists in "making live and letting die." New forms and rationalities of government, in other words, aim to individualize the objectives and behaviours of government, thereby massifying practices of good conduct across the population. This would ensure the participation of subjects in the development and prosperity of society and, in particular, the promotion of liberal behaviours and capitalist political economies. While Foucault's model of new governmentalities was largely focussed on the internal regulation of European states, governmental ordering functions that "make live and let die" are complicated by demarcations of race/racism in European colonies. In colonial states, this required that colonized peoples would acquiesce to, and participate in, the promotion of settler colonialism.

\section{Race/Racism, Colonial Governmentality, Normalizing Society}

Despite Foucault noting that these emergent powers of regulation are - at their very essence - racialized instruments, he did not build upon these claims. Nonetheless, Foucault is very explicit about the colonial influences and the centrality of race on the emergence of these knowledge systems. Foucault introduces the notion of the "break" to explain how race is manipulated by colonial authorities in the process of regulating and sorting categories of bodies within the population. Within "the population," hierarchies among races inform the models and norms of regulation. In Foucault's (2003:243-258) discussion of the "'biopolitics" of the human race" in "Society Must be Defended," he introduces the argument that race/racism emerged as a sorting and fragmenting function to develop techniques that "make live and let die." Where the power of sovereignty 
includes the control of life as "an object and its objective," racial discourses present a "break" that create "caesuras" and fragment the biological "continuum addressed by biopower" (Foucault, 2003:255). Foucault writes that a hierarchy of races, the good to the bad, creates a biological-type relationship anong the races where "the death of the other, of the inferior race is something that will make life in general healthier: healthier and pure" (ibid.). Within these discourses - what Foucault termed the discourses of "race war" - those that are not "healthy and pure" present a "break" in the sense that they constitute a threat to the population-as-species. Foucault (2003:256) states,

The reason this mechanism can come into play is that the enemies who have to be done away with are not adversaries in the political sense of the term; they are threats, either external or internal, to the population and for the population."

Colonial governmentalities, in this sense, incorporate perceived knowledge of racial threats and demarcate accordingly. Sorting/fragmenting functions are then superseded by mechanisms of security which aim to intervene upon, neutralize or transform, potential threats to the population. However, for Foucault, the demarcation of race is not strictly biological. While racism based on 'otherness' informs many of the cultural and political stereotypes of the frontier, racism from the biopolitical perspective is focussed on forms of behaviour and conduct. Often these are conflated with stereotypical characteristics of race - the presumption that all Indians are lazy, for example - however the defining characteristics of biopolitical governance are drawn from the activities at the site of intervention/problematization. Through the surveillance and regulation of various forms of conduct, colonial governmentalities delineate categories of "good" and "bad" Indians based on their behaviours. In the North-West, Indians are categorized on a hierarchy of conduct. As an internal population to be assimilated into the 
Canadian order, this presents a distinction where not all Indians are "bad." "Bad" Indians are those that do not acquiesce and participate in behaviours conducive to settler colonialism and, having been characterized as such, must be neutralized because they represent a threat to the health of the aggregate population.

Race/racism in the context of these colonial transformations adopts a layer of complexity. Foucault (2007:19) writes that to understand populations requires aggregating knowledge on the bads, risks, threats, etc., which can never "be completely suppressed." Governmental strategies become an exercise of guiding and delimiting "indefinite series" of probabilities. Foucault (2007:20) explains, "I think the management of these series that, because they are open series can only be controlled by an estimate of probabilities, is pretty much the essential characteristic of the mechanism of security." As he details, this indefinite series of possibilities within a population must be determined, monitored, and evaluated based on the norm.

Race/racism is not based on biological criteria but, instead, established by the aggregate behaviours that are translated into normative expectations of conduct. Importantly, the determination of "the normal" is characterized against its inverse: the abnormal. In his 1974-75 lectures Abnormal, Foucault (2003b, 316-317) claims that the racism psychiatry gave birth to is "racism against abnormal, against individuals who, as carriers of a condition, stigmata, or any defect whatsoever, may more or less randomly transmit to their heirs the unpredictable consequences of the evil, or rather of the nonnormal, that they carry within them." McWhorter (2009) has demonstrated that the modern racism traced by Foucault is about racial purification; it defines the abnormalities it identifies as racial impurities or as threats to racial purity. She writes (2009:34) that 
within modern regimes of power alleged abnormalities result in groups of people being "despised, excluded, contained, managed, or exploited in ways that often threaten, harm, and oppress them." However, in the Anglo-American development of modern racism, McWhorter (2009: 34) demonstrates "the fundamental issue is not religion or skin color per se; it is abnormality. Skin color and religious affiliation are taken as marks of abnormality."

Marks of abnormality lend racial thinking its semblance of biological legitimacy. In colonial spaces, Indianness and other marks of otherness are subjected to normalizing judgement and the supposed supremacy of whiteness. White supremacy, however, is not exclusively defined by skin pigmentation - although this is certainly common - but comes to embody behaviours associated with whiteness. Foremost in the North-West, and in Canada more broadly, these normative traits were defined by Victorian notions of work ethic, individualism, hygiene, sexuality, rationalism, etc. (Leighton, 1983). Shewell (2005:91) notes that policies and expectations placed on Indians were based on "a Puritan view of poverty as an individual, moral shortcoming." The essential task of Indian officials was "to instil in Indians ideas about the moral virtues of work, self-sufficiency, and, presumably, the promise of eternal reward or punishment" (Shewell, 2005:91). Notably, the expectations placed on Indians during period of 1873-1912 were the same as those placed on destitute whites who were not seen as embodying the behaviours of white dominance.

Policies targeting Indian populations operated within an assimilatory project that presupposed that forms of conduct can be re-subjectified. In other words, Indians can adopt "white" practices and move upwards in the biopolitical hierarchy of behaviours. As 
I will demonstrate throughout the following chapters, Canadian colonial authorities have marked settler conduct as synonymous with "good" conduct. However, this also functions in reverse. Foucault also demonstrates that the biopolitical power to "make live and let die" is complemented by a killing function that targets internal enemies to the population. "Bad" Indians are such internal enemies. They represent a threat to the population and, as a subrace, threaten the integrity of "good" Indians as well as the population in general. Therefore, in defence of the population, these threats are targetted by mechanisms of security.

Scholars who have followed Foucault's preliminary. work on the function of race/racism in colonial states have noted much of his lectures focussed too much attention to the interior of the European state (Hussain, 2003; Inda, 2005; Moreton-Robinson, 2006). Although Foucault clearly links the emergence of governmental and biopolitical rationalities within the transformations of $19^{\text {th }}$ century colonialism, he has been critiqued for the omission of particular developments within European colonies. Other scholars have, however, taken Foucault's analytical framework of biopolitics to isolate the particular functions of race, security, and population in colonial spaces (Hussain, 2003; McWhorter, 2009; Moreton-Robinson, 2006; Scott, 1999; Stoler, 1995; Terranova, 2009; Venn, 2009). Moreover, several authors have followed Foucault's fragmentary lectures and taken up the task of detailing processes of colonial governmentalities and the strategies and instruments that aim to interpolate the terrain and populations claimed by colonial sovereignty (Mawani, 2005; Scott, 1999; Stoler, 1995). In accord with these works, Foucault's theoretical framework is useful for evaluating the radical transformations that were underway in the North-West during the last part of the $19^{\text {th }}$ 
century.

It is precisely the experience of state formation and the political economy of modern liberal-capitalist states that produce colonial governmentalities. Scott (1995:208) characterizes the move from extractive-effects on colonial bodies to governing-effects on colonial populations as a "new game of politics that the colonized would (eventually) be obliged to play if they were to be counted as political." Colonial governmentalities are the regulative structures constructed to accommodate new rationalities of rule focussed towards the "governing-effects" on the conduct of the colonized. "One of the things the new game of politics came to depend upon," writes Scott (1995:208), "was the construction of a legally instituted space where legally defined subjects could exercise rights, however limited they were." In the Canadian colonial context, the emergence of these technologies are largely a result of the political contexts and desires of the budding Canadian state.

Immediately following Canadian confederation, the frontier territory of the NorthWest became intensely gazed upon as an object for expansion. This was accompanied by a project of "law and order" that aimed to secure these spaces, although only after its domestication was imagined. Under this rationale, claimed territories also claim the bodies, the populations, within these spaces. Non-disciplinary actors within those spaces become construed as dangers, such as Indians who exhibit "bad" behaviours and become identified as "bad Indians" who endanger the population. However, for the most part, they are not "enemies of the state," and are not targeted to "make die" by classical regimes of sovereignty. While those tactics do co-exist within the triangle of governmentality, under the new regime of practice these bodies and populations are most 
often subjected to biopolitical forms of regulation. As will be discussed in detail below, this includes a complex array of security mechanisms aimed simultaneously at the paradoxical objectives of assimilation and containment. These span virtually all aspects of life in the frontier, aiming to reform all manners of Indian behaviour, as well as remove Indians from lands reserved for white settlement.

The regulatory apparatus of colonial governmentality is animated by what Rose and Valverde (1998:542) call "legal complexes," which include legal practices, legal institutions, statutes, legal codes, authorities, discourses, texts, norms, and forms of judgment. Legal complexes evoke and legitimize the actions of colonial agents: from the "alchemy" of sovereignty to minute details of farming programs and pass laws that are discussed in these chapters. Moreover, in the North-West, authorities that arose from legal complexes were invoked by the regime of "law and order" that aimed to domesticate the frontier. In the form of Indian Affairs agents and NWMP officers, these actors are the on the ground instruments of colonial governmentalities and the practitioners of frontier justice. As discussed in chapters Two and Three, marks of abnormality in the form of indigenous 'otherness' become discursively framed as fiduciary responsibilities, wards, "burdens," "infestations," and objects of regulation. While the settlement of the Canadian prairies is often depicted through "the myth of empty origins" (see Mawani, 2007), the transformation of the North-West is replete with violence and injustice. For this reason, reviewing these archival records is important in questioning the normative values that underwrote development in the North-West and, in revealing how processes of ordering are not remote or historical, they serve to demonstrate the continuity of these rationalities in contemporary practices. 


\section{Why a "Canadian" Account of "Frontier Justice"?}

Throughout this thesis, I aim to illustrate how frontier justice is a set of rationalities and practices informed by the desire to develop a prosperous and unified Canadian legalpolitical order. In Canada, race was a central element to the governance strategies of the frontier (Mawani, 2005; Harring, 1998). The theme of race and racism, as I will argue, assumes a central focus in understanding the relations of power that operate on/in the colonial spaces of the Canadian frontier. Race emerges in colonial discourse as both a biological and social criteria, where 'otherness' prefigures technologies and interventions developed by colonial authorities. With the construction of 'aboriginality,' 'Indianness,' etc., Canadian officials have mobilized various mechanisms of security to address what was commonly referred to as the "Indian problem." Although, the emergence of the "Indian problem" is demonstrative in itself.

Perhaps the most revealing transformation in the rationalities of rule between the HBC-governed North-West and the newly-formed Canadian North-West Territories is the discursive shift surrounding the governance of the indigenous population. Under the HBC-British mandate, colonial officials referred to the "Indian question" (see McNab, 1983). While assimilation was seen as inevitable by British officials, the "Indian question" was a subject of aloof theoretical debate among the upper echelon of British elites. Practices on the ground during the HBC era were far removed from these debates. However, under Canadian officials the "Indian question" quickly transformed into the "Indian problem." This discursive shift underscores the problematization of Indian conduct by Canadian officials. Indigeneity is this contrasted with the new norm of Canadian, white, settler society: as an abnormality that must be neutralized. This demonstrates a demarcation of colonial governmentalities that surpass objectives of 
wealth-extraction and the potential inconvenience of indigeneity in the frontier. Instead, abnormality is a problem to the prosperity of the population and, therefore, must be subjected to the jurisdictional norms of Canadian order. Indianness must be assimilated, transformed, or erased. In this thesis, I localize these themes, examining the particular regimes of regulation that take form in the ordering of the North-West.

Unlike the Wild West narrative popular in the United States (Slotkin, 1992), the mythical man of the Canadian frontier is not expressed by individualist Jesse James typology. Rather, Canadian frontierism embodied a collectivist law-enforcement typology symbolized quintessentially by the Mounties (Cross, 1970:3; Mackay, 2002; Walden, 1982). While colonial practices in Canada do not have a history of outright violence that characterizes Western expansion in the United States (Brown, 1970), the Mounties nonetheless have a sordid history of oppression. Despite their often romantic depictions, even one NWMP/RCMP historian has described policing in the North-West as a form of "benevolent despotism" (Macleod, 1976:22). The transformations that took place in the North-West were not the product of a "gentle occupation" nor were indigenous peoples' treated "fairly" (Coates, 1999). As Blomley (2003:130) argues, "Violence is not aberrant, but central to law. It is not exceptional, but quotidian." The effects of becoming subjected to radically transformative powers of Canadian governance was far from peaceful and, for most indigenous people, a quotidian experience of displacement from space, identity, and community.

Moreover, contemporary colonial practices remain centred on rationalities of colonial power which have been normalized. The task of challenging these regimes of practices is difficult. Furniss (1999:55) notes that "frontier myths" are a set of "a highly 
flexible set of metaphors, images, symbols, and narratives" that have deeply embedded themselves within dominant cultural norms. These norms sustain the ideals of Canada as a multicultural, liberal democracy, and eschew the association of government authorities with violence. An expression of these sentimentalities is evidenced by Prime Minister Harper's quip that Canada has "no history of colonialism." In this thesis, I discuss the roots of these myths and demonstrate how the celebration of the discovery thesis, the settlement of the prairies, the legacy of the NWMP/RCMP, and Canada as a wealthy and prosperous nation, makes the task of challenging colonial injustice remarkably unpopular.

Some scholars have discussed (Tully, 1995; Harding, 2006) the significant political and cultural barriers that exacerbate our collective abilities to "think against colonialism" (Ladner, 2001). Similarly, Foucault (2003a:76), notes that normalizing discourse "is a discourse that has a great ability to circulate, a great aptitude for metamorphosis, or a sort of strategic polyvalence." The strategic polyvalence of EuroCanadian normalization can be demonstrated in many cases today: confrontations over land and indigenous rights, from Six Nations, to Barriere Lake, to Grassy Narrows, the Alberta tarsands, or the vast majority of land in British Columbia that remains unceded territory (to name only a few). Within settler society, the accumulation of privileges and wealth derived from the theft of indigenous land and resources has encultured a strong resistance against "accommodating" to the special needs of indigenous peoples'. 11 Conceptualizing frontier justice as a process of ordering and transformation contributes to the numerous academic efforts to problematize dominant histories; a small contribution to

\footnotetext{
"Right-wing and reactionary groups frequently criticize what they consider "special accommodations" made for indigenous peoples. Often these claims refer to specific treaty or legal responsibilities of the Canadian government. For academic examples of these discourses, see Flanagan (2000) and Flanagan et al (2010).
} 
un-thinking the colonial practices that sustain the order/ordering of the Canadian state.

\section{Note on Methodologies}

This thesis takes the form of a genealogy, inspired largely by the genealogical methodologies of Foucault. Often genealogy is an exercise in unravelling, an attempt that "takes up a posture of subversion towards fixed meaning claims" (Ferguson, 1993:6). Borrowing from Nietzsche, Foucault (1984:81) presents genealogical methodology as a means to map and unearth the messy, minute, accidental, and unconnected histories "that give burth to those things that continue to exist and have value for us." Foucault refers to this aspect of genealogy as an alternate form of narrative, one that challenges any semblance of objective claims. He wrote that the genealogical approach was "an unstable assemblage of faults, fissures, and heterogeneous layers that threaten the fragile interior from within or from underneath" (Foucault, 1984:82). In opposition to universalized or scientific projects of truth, Foucault suggested that genealogical methods should reveal subjugated knowledges capable of struggling against, unitary, formal and scientific discourses. Scholars should proceed by charting power within a "descending-ascending" analysis and commence the examination of power at infinitesimal sites. Advancing from below, it would be a methodology that proceeds by considering how power becomes discursively produced, mobilized, appropriated, and ultimately transposed (Prasad, 2009).

Genealogical methodology highlights constitutive formations of power. Foucault argues that, unlike a chronological account of history, genealogy explains the emergence of rationalities and practices in their dispersed forms, specifically in light of problematized subjects. In discussing his methodology for Discipline and Punish, he noted that "in order to get a better understanding of what is punished and why, I wanted to ask the question: how does one punish? ... rather than asking what, in a given period... I 
wanted to ask how these divisions are operated" (Foucault, 1991b:74 - emphasis included). As opposed to focussing strictly on institutions, theories, or ideologies, Foucault's interpretive diagram suggests that analyzing "regimes of practices" can reveal conditions that make certain realities "acceptable at a given moment" (Foucault, 1991b:75). This lends to a focus on the emergence of programs, technologies, apparatuses (dispositifs). Following Foucault, this project looks at the emergence of strategies and practices that surround the period of the North-West Rebellion. Looking at sites of problematization, this approach highlights the constitutive modes of power in the frontier and, emerging from these particular contexts, the "regimes of practices" created by colonial powers to order the frontier.

To discuss the realities of the frontier during the time of the North-West Rebellion, I examine a broad series of records from the Library and Archives Canada (LAC). The records detailed throughout these chapters include upper-echelons of the bureaucracy and policing establishment, as well as on the ground agents of the Canadian state. They are comprised of 1880 s correspondence records from the North West Mounted Police (NWMP), the Office of Indian Affairs, and other agents of the government. Correspondence records are supplemented by reports and other documents stored in the archival collections from the period. Additional secondary source material, as well as analytic and empirical studies from post-colonial studies and other related fields, contribute to the contextualization of my research within the field of social-legal studies.

The archival files reviewed herein are largely from two departments: the North West Mounted Police and the Department of Indian Affairs (DIA). These were the two principle departments involved in the day-to-day operations of the North-West. It should 
be noted that the DIA archive also contains the records of the Lieutenant-Governor of the Northwest Territories, who was responsible for governance in the territories. These departmental records share a good deal of overlap with other departments, as well, and these are also included herein. There are also a number of files from the Prime Minister's Office, particularly during the years that comprised the John A. Macdonald administrations. ${ }^{12}$ As an indication of the political importance of the "Indian problem," Macdonald was also the Minister of Indian Affairs. Having the Prime Minister take-on a cabinet portfolio is an unusual and very uncommon arrangement within Canadian government and politics. However, it is illustrative of centrality (and threat) of indigeneity, as well as the importance of Indian Affairs to the National Policy and, subsequently, to the health and prosperity of the nation.

The NWMP collection reviewed at the LAC for this research is by no means the complete record of all activities of the NWMP during that period. In order to focus the scope of this research, I limited my examination to official correspondence files between detachments, headquarters, and other government branches for the period of January 1886 , to December 1886 . This material relates largely to the details of patrols and securitization that is detailed in Chapter Three. This time period was selected for two reasons. I wanted to examine reactions, discourses, policies and practices in the immediate aftermath of the Rebellion. Due to the political and psychological significance of the Rebellion at the time, it seemed probable (and proved correct) that these records would be fertile ground for discussing colonial governmentalities. Additionally, I

\footnotetext{
${ }^{12}$ Macdonald served two stints as Prime Minister. First, as Canada's first Prime Minister from 1867-73, then a second term from 1878-91. In the interim he was the leader of the official opposition during Alexander Mackenzie's prime ministerial term. Macdonald was the leader of the Conservative Party from Confederation, in 1867, to his death in 1891.
} 
expected to find precautionary preparations for repeated "troubles" and focussed particular attention to policing strategies that formed the basis of securitization mechanisms. As I will discuss further below, over the wide-ranging topics of discussion, Indian" troubles" are - by far - the leading concern of the authors. Secondary concerns included enforcement of prohibition laws, the maintenance of horses and barracks, as well as a number of cases of desertion. The most substantive element of data comes from Monthly Reports, sent to NWMP Commissioner Lawrence Herchmer from the various outposts and detachments, but other data is gleaned from letters addressing specific issues. There are also records from other departments from this period, and have been included, to a lesser degree, in the analysis. NWMP files during (and before) the Rebellion are included in the DIA records, another reason to limit the search of the NWMP archive to the year 1886 .

The LAC has a section of the Department of Indian Affairs devoted to the NorthWest Rebellion. The period spans correspondence from 1881 to 1888 . It includes everything from official reports, media clippings, telegrams, and many volumes of correspondence that relate directly to affairs surrounding the Rebellion. In order to limit the scope of these files, I focussed mostly on correspondence files, with a particular interest in files relating to indigenous groups. This resulted in not reading many files related strictly to Louis Riel and other Métis groups.The rationale to focus on indigenous groups is two-fold. First, histories/historians have, for the past 125 years, largely focussed on issues surrounding Riel and the Métis, at the expense of Indigenous groups (Stonechild and Waiser, 1997). The second rationale is more strategic. Many texts have addressed what assemblages of rule developed in colonial Canada. Especially in the field 
of Aboriginal law, there are many excellent volumes that detail the Indian Act(s), the pass laws, the repression of religious practices, residential schools, as well as the violence and racism that underwrote these histories. My objective is, however, to ask how these complexes emerge. Following the methodological suggestions of Rose and Valverde (1998), I have started with files that problematized certain Reserves and individuals as troublesome. These files focused on, but were not limited to, the Blood reserve, Poundmaker, Lucky Man, and the movements of Big Bear and Little Poplar.

These correspondence records offer first-hand accounts, written by the hands of the localized colonial agents and the leading elites that crafted these technologies of rule. Through focussing on the "problematized" subjects, this research addresses how colonial governmentalities addressed these problematizations, speaking directly to the strategies that are produced by colonial authorities. As Rose and Valverde (1998:545) note, legal studies tend "to presuppose that objects and problems form within the workings of law itself." By "de-centering" law, researchers can identify how economies of power are mobilized to address particular problematized themes. Thus, they can "analyse the role of legal mechanisms, legal arenas, legal functionaries, legal forms of reasoning and so on in strategies of regulation" (ibid.).

Re-visiting archival records is integral to narrating the strategies and practices developed to domesticate the North-West. In asking how the emergence of particular strategies and rationalities were constituted, examining these archival records can illustrate political and economic contexts that animated the period. These records reveal challenges to authority and sovereignty that arise in this period and underline the motives behind the program of ordering the frontier. Following Foucault, the objective is not to 
strictly analyze ideologies, institutions, or theories, but to focus on practices, "with the aim of grasping the conditions which make these acceptable at a given moment" (Foucault, 1991b:75). Following these suggestions, my objective with this project is not to write a history of the North West Mounted Police or the Department of Indian Affairs. Rather, my objective is to write about the process of policing and regulating in the NorthWest. Particular colonial governmentalities during the period surrounding the Rebellion produced a vast array of policing and regulatory strategies and techniques. These included patrol systems, pass laws, farming training, surveillance programs, communications tools, policies on food, annuity payments, rations, etc. Most if not all of these projects were structured by colonial governmentalities that explicitly aimed to transform the lives and lived experiences of indigenous peoples and their frontier territories in both the neutralization of potential threats, as well as the shaping of certain forms of conduct. In this sense, the story of policing and regulating the North-West is the story of frontier justice.

\section{Chapters Outline}

A good deal of scholarly research has documented legal histories of colonial expansion in Canada. ${ }^{13}$ This project is a small contribution to these studies, largely through addressing the question of how economies of power focussed on populations produced categories and norms of race/racism, and evoked mechanisms of security to ensure health and prosperity of the Canadian settler state. By addressing these histories genealogically, I hope that the material presented can offer a glimpse into a time-space largely recognized as the end of the "frontier era." To give adequate treatment to these histories, this thesis is

\footnotetext{
${ }^{13}$ Throughout this project, I have benefited greatly from a number of historical texts. In particular, these include: Getty and Lussier (1983), Baker (1998), Carter (1990), Barron and Waldram (1986), Francis (1992; 1997), Furniss (1999), Harring (1998), Hall (2003), Knafla and Swainger (2005), Miller (1989; 2009), Petitpas (1994), Stonechild and Waiser (1997) and Tobias (1977; 1983).
} 
divided into three chapters.

Chapter Two defines the emergent colonial governmentalities in the pre-Rebellion years of the North-West. By engaging literature on colonial governmentalities, this chapter demonstrates that, unlike literature on governmentality that is strictly concerned with the "technologies of the self" or focussed solely on contemporary liberal societies (Rose et al., 2006; Gordon, 1991), colonial governmentalities balance sovereign and biopolitical techniques in the process of colonial settlement. As "conjoined and braided" stratagems (Mawani, 2009) they are integral to the ordering of the frontier.

This chapter also details surveillance programs targeting indigenous leaders in the lead-up to the Rebellion. Some of these programs included visible government authorities such as NWMP officers and Indian Agents. However these surveillance projects also included clandestine surveillance by Métis traders and Christian missionaries in the employ of the Department of Indian Affairs. This material demonstrates how certain indigenous leaders were problematized, encoded through perceptions of "dangerousness," and subjected to an apparatus of securitization based on presumptions of danger. Furthermore, it substantiates Foucault's notion of the "break" as a mechanism of substantiating the "good" from the "bad," the healthy population from the population threat, and as a determination of who will live and who should be allowed/made to die. The chapter concludes with an examination of correspondence surrounding the infamous "Craig Incident" from the summer of 1884.

Chapter Three details correspondence records in the post-Rebellion years of the North-West Territories. The correspondence records regard the acceleration of an expansive post-rebellion effort to establish "law and order" in the North-West. The focus 
of this chapter will be to detail emerging policing and regulative strategies, while combining these accounts with the broader ambitions of the Canadian settlers to domesticate the North West. The chapter will explore how the demarcation of spatial territory - and the development of knowledge systems based on a particular geography is twirned with the production of governable subjects as "the population." Through "circulations" (Foucault, 2007) the subject of "the Indian" emerges as a focus of intervention, regulation, and anxiety. This chapter traces the role of the newly implemented patrol system in rendering the vastness of the frontier into a matrix of secured pathways, outposts and remote networks of knowledge (and presumption) into a central mechanism for regulating and producing the subject-object "Indian." This chapter concludes with a discussion of anxieties in frontier spaces, and the mechanisms of security (Foucault, 2007; Pasquino, 1991) that respond to anxieties and threats of dangerousness in the space of European order.

The Conclusion briefly summarizes Rebellion and Post-Rebellion Indian policies. It demonstrates the consolidation of rule in the post-Rebellion period, specifically in regards to Ford's (2010) stipulation concerning the reconciliation of territory, sovereignty, and jurisdiction. With the ability to apply continuous jurisdiction over the North-West, the post-Rebellion period witnessed a rapid and largely uncontested period of settlement and development. This course of development was enabled by the repression of indigenous groups. The Conclusion underlines the coeval existence of sovereignty and biopolitical techniques undertaken to order the frontier. Underlining the fluidity of normalizing society, I argue that abnormality-indigeneity in the space of Euro-Canadian order is a constant source of anxiety in settler society. Therefore the ordering of internal 
populations is always plagued by the marks of abnormality which remind settler society of colonial legacies that continue to shape relations in Canada. My conclusion explores the source of lingering anxieties within settler societies: the threat that Indians might take back what is rightfully theirs. 


\section{Chapter Two}

To Feed Them or Fight Them: Dangerousness, Internal Enemies, and Biopower.

This chapter defines emergent colonial governmentalities in the pre-Rebellion years of the North-West. These practices are 'emergent' insofar as the rationalities that inspire them are also 'emergent': they are new practices because the idea of domesticating the frontier was only freshly imagined by colonial authorities. To reconcile the desire to govern with their ability to govern, Canadian colonial authorities devised a program to reconcile sovereignty and jurisdiction by developing an extensive regulatory apparatus. As I detail in this chapter, the emergent regulatory apparatus implements mechanisms of security that aim to isolate and neutralize perceived elements of dangerousness, as well as seeking to develop means of regulation that cultivate new modes of behaviour and order, based on liberal ideals of conduct. However, as I detail throughout this chapter, emergent biopolitical strategies are not practiced independently from sovereign or disciplinary power. Contributing to literature on colonial governmentalities (Scott, 1995), I argue that biopolitical and sovereign rationalities of government do not appear successively or autonomously from each other. Nor, as Foucault (1991a:102) warns, should biopower be considered a "replacement" to sovereign power. Rather, functioning as parallel stratagems, both are integral to the ordering of the frontier.

Distinctions between biopower and sovereign power are among the most contentious aspects of Foucault's work (see Mawani, 2009:18). However, scholars have noted that these rationalities of governance do not have to be theorized - or practiced successively (Dean, 2002). In Colonial Proximity, Renisa Mawani (2009:19) details how the mixing of racial identities in early twentieth century British Columbia produced 
interconnections between sovereignty and biopolitics that were "conjoined and braided as opposed to distinct." ${ }^{\prime 14}$ These practices aimed to shape the conduct and choices of indigenous people, "while at the same time determining matters of life and (cultural) death though liberal and illiberal policies." Interconnections between strategies of biopolitics and sovereign power are particularly evident in colonial practices and, as I detail in this chapter, examples of these coeval strategies produce a mix of biopolitical rhetoric and practices of sovereign power in the pre-Rebellion North-West.

Building on a Foucauldian notion of colonial governmentalities helps interpret the particular transformations that swept through the North-West immediately following the transfer of Rupert's Land. Scott (1995) argues that colonial governmentalities arise when imperial powers shift objectives from wealth-extraction to focus on permanent settlement. In the North-West, the nomadic character of Indian society represented an impediment to the settlement program envisioned by Canadian officials. To remedy this perceived impediment, a host of new Indian policies during the 1870-1885 period aimed to settle and domesticate prairie Indians. Largely dependent on the reserve system inherited from British policies in Eastern Canada, the dominant focus of this system included agricultural training and work-for-rations schemes (Carter, 1990; Shewell, 2005). As a series of policies aimed at reforming the conduct of prairie Indians, these represent emergent biopolitical strategies that were particular to the North-West. However, as I will detail, while these programs were of rhetorical importance, efforts to implement these biopolitical programs were ambivalently pursued and government authorities were quick

\footnotetext{
${ }^{14}$ Mawani (2009:18) notes that Gilroy and Mbembe are among the most prominent critics of a strictly decentralized and successive notion of biopower, suggesting that colonial histories were much different than those of Western Europe that Foucault sketched out, particularly because of military violence and martial law.
} 
to use tactics of sovereign power to ensure that, in the words of NWMP commander Crozier, the law "be carried out under any circumstances" (see below).

Recognizing the "conjoined and braided" relations between biopolitical and sovereign strategies casts a shadow over the mythologies of a "bloodless revolution" that is celebrated in dominant narratives of Canadian state formation. ${ }^{15}$ Certainly, numerous projects unfolded under the direction of the Canadian federal government that had, at the very least, a discursive commitment to transforming Indian subjects. However, behind the rhetoric of emergent biopolitics, the domestication of the West relied upon practices of sovereign power to force Indian populations under the legal authority of the Canadian state.

This chapter highlights a series of events within the framework of "frontier justice" to explain a) how colonial governmentalities exercise a balance and co-reliance upon sovereign and biopolitical strategies of rule; and b) how mechanisms of security became activated by the promulgation of stereotypes of dangerousness and threats produced through surveillance. The latter points detail efforts to neutralize perceived threats, or what Foucault calls "internal enemies" of the population. As I will discuss, knowledge of these threats is gathered through covert surveillance practices. Nevertheless, this chapter begins first with a brief summary of the historical context of the period from 1870 to immediately before the 1885 Rebellion. I will detail the political-economic basis of the transformation of the West, particularly the influence of Prime Minister Macdonald's National Policy. Further, I will discuss how the National Policy implemented policies of settlement, treaties, and policing, so that the prairies could be

\footnotetext{
${ }^{15}$ In his 1911 history of the NWMP Arthur Lincoln Haydon infamously wrote that the NWMP quickly created a "bloodless revolution" in pacifying the West (quoted in Francis, 1992: 64).
} 
imagined within a unified political jurisdiction that stretched from sea to sea.

Following this sketch of the historical context, I examine two series of correspondence: first, records that pertain to a surveillance program initiated by Canadian authorities to track and categorize prominent indigenous leaders; and second, records that relate to the "Craig Incident" of 1884 . The series of correspondence on indigenous leaders discusses individuals - such as Big Bear, Poundmaker, Beardy, Little Poplar, etc. - who the Canadian government identified as problematic. In most circumstances, they were leaders who objected to the Canadian government's non-fulfilment of the treaty responsibilities. In differing capacities these individuals were involved in building a panIndian movement to press Ottawa for treaty concessions. While there were many techniques that the Canadian government employed to gather information on these political developments, I focus on one in particular: the reports and letters from an undercover Métis operative in the employ of Department of Indian Affairs (DIA), named Peter Ballendine. While the documentary record is scarce, Ballendine's correspondence reveals a campaign of surveillance and infiltration, in what is possibly the first undercover operation in Canadian policing history. Through the covert Ballendine correspondence, I trace how these problematized leaders are imbued with characteristics of "dangerousness" (Castel, 1991; Lianos and Douglas, 2000) and became isolated as targets for neutralization. Perceptions of dangerousness also translate their political resistance into a threat to security and order, resulting in pre-emptive strategies to contain and prevent their influence among the broader population.

The second series of records examined relate to the Craig Incident, in the summer of 1884. The Craig Incident was a dramatic standoff provoked when the NWMP tried to 
make an arrest during a large thirst dance on Poundmaker's reserve. I argue that the Craig Incident demonstrates the limits to emergent biopolitical strategies that were designed to reform the conduct of Indian subjects. As I detail below, the Craig Incident demonstrates that tensions in the frontier had elevated to a point where decentralized and inducive biopolitical strategies were not sufficient in ruling an unruly Indian population. Instead of relying simply on strategies focused on the 'conduct of conduct,' the Canadian government was faced with a strictly sovereign-disciplinary decision: they would have to either feed them or "fight them." While British and Canadian authorities had long considered Indigenous populations as wards of the state (Paul, 2006), this culmination represents the emergence of colonial governmentalities that interpolate the Indian population into a "new game" (Scott, 1995) where the rules are created and enforced by Canadian authorities. Imposing these rules involved both sovereign power and biopolitical techniques balanced to suit the immediate objectives of colonial agents. However, as I discuss, biopolitical practices are reduced to a hollow rhetoric from Ottawa, while practices on the ground turn adopted tactics associated with sovereign power in the build up to the Rebellion.

This chapter concludes with a discussion of how surveillance and policing practices produced forms of knowledge and threat, and how these forms of knowledge intertwined with political and economic transformations that can be explained through Foucault's (2003) concept of the birth of "state racism." I position the location of race within Foucault's (2003) notion of "internal enemies," where aspects of a population are categorized as threats to the health and prosperity of the population. As a process of frontier justice, the sorting, neutralization, and/or elimination of internal enemies - 
through mechanisms of security - demonstrates how colonial governmentalities operate to pacify and bring order to the frontier, and justify the murder of the sub-race of "bad" Indians. While I conclude with a discussion of the strategic balance of biopoliticalsovereign practices, the chapter serves to narrate a short period of time - 1870 to 1884 where the avarice of European expansion radically transformed the possibilities of conduct and lived experiences that order the frontier.

\section{The Frontier Context: Indian Policy in the Prairies, 1870-1885.}

Beginning in 1870, the North-West was to undergo a series of radical transformations.

Prior to this time, Rupert's Land was a vast area of land that encompassed most of current Alberta, Saskatchewan, as well as the Yukon, Nunavut, and Northwest Territories. When the Hudson's Bay Company transferred control over Rupert's Land to the Dominion of Canada in 1870 , the new "North-West" Territories were re-imagined. Immediately, this spurred ambitions to settle these frontier territories. Before the Canadian imagination gazed upon these territories, the prairie regions were mainly populated by thousands of indigenous people, organized through mobile societies that travelled between seasonal camps. ${ }^{16}$ Only small European settlements were scattered throughout the frontier, mostly in the form of HBC outposts and various traders, while travellers and small settlements throughout the South tenuously linked British Columbia with Eastern Canada. There were also Métis villages and communities scattered through the territories, as well as a regular influx of U.S. traders from the other side of the Boundary Line. Despite these small European settlements, the vastness of pre-1870 prairies were Indian Country.

What existed as Indian policy in the broader Dominion of Canada was a mixture

\footnotetext{
${ }^{16}$ In 1885 , the population of the North-West was 48,362 . Of that total, 20,170 were Indians and 2,254 were Métis (the category of "white" accounted for the remainder). However, counting only the districts of Saskatchewan and Alberta (and not including Assiniboia, which is now Southern Saskatchewan) Indians and Métis outnumbered whites by 16,915 to 9,364. (Collected from population graph in Carter, 1990:283).
} 
of policies influenced by British, French, and Canadian practices. In 1860, the responsibility for Indian affairs was transferred from the British Colonial Office to the government of the Province of Canada. Despite agreements made between Indians and the Crown, no indigenous peoples or representatives were consulted concerning this transfer (McNab, 1983:100). Moreover, the transfer was approved despite the objections of indigenous groups (Tough, 1992). Following Confederation in 1867, the sale of Rupert's Land in 1869 formalized a transfer of sovereignty over indigenous communities and, again, there was no pretence of, or attempt at, consultation. In addition, during the period before the Dominion acquired the North-West, politicians and the bureaucracy in Ottawa gave almost no thought to the plains Indians (Carter, 1990:25). Not surprisingly the sale, described by Spry (1983) as the "tragedy of the loss of the Commons," resulted in a rapid period of transition from common property to a private property regime. Conscious of the expansionary ambitions of Canadian authorities, the Indian and Métis populations of Manitoba and the North-West Territories would not allow settlement past the Red River until Indian ownership of the land had been recognized and duly surrendered (Tobias, 1977). In response to this considerable agitation, particularly from the French Métis influenced by Louis Riel, the Canadian government created the province of Manitoba (which incorporated many of Riel's demands) and established the process of Treaty negotiations, known as the "numbered treaties" or "Morris Treaties," to reconcile questions of land ownership with indigenous peoples'. ${ }^{17}$

Following the transfer of Rupert's Land, Ottawa developed a new interest in

\footnotetext{
${ }^{17}$ Alexander Morris wrote a detailed account of his journey West to negotiate the Numbered Treaties (See Morris, 1971[1880]). Morris' accounts are still widely referenced. For a critical legal examination of the Morris Treaties, as well as an overall analysis of British-Canadian treaty-making from contact to the present, see Miller (2009).
} 
establishing a systematic policy of settlement. Although not formally adopted until 1878, Prime Minister Macdonald's National Policy was the framework for the opening of the West (Brown, 1964; Russell, 1979). Prairie inhabitants were irrelevant to this program, only insofar as their lands were needed to establish the domestic economy envisioned by Eastern politicians. Macdonald's National Policy - which flew under the slogan "Canada for Canadians" (see Creighton, 1988) - rested on three explicit pillars: high tariffs for the manufacturing industry to boast Eastern industrialism, the rapid construction of the Canadian Pacific Railway (CPR) to link East and West, and substantial immigration to fill the territories with white, European inhabitants. Although the deal to construct the CPR was not completed until 1880 , the Canadian government made quick progress on the program of settlement. In particular, the Dominion Lands Act of 1872 opened wide swaths of land for settlement and, as I discuss in more detail in the next chapter, the 1873 NWMP Act ${ }^{18}$ was passed. This opened "the road to an enormous territorial promise" (Turner, 1950) with the establishment of a permanent and professional security force throughout the prairies. Harring (1998:277) has argued the deployment of the NWMP demonstrates a policy of "sending the law ahead of settlement" in the prairies.

In addition to the three formal pillars of Macdonald's policy, Green (1995) argues that treaty-making was the fourth (but unacknowledged) component of the National Policy. Green notes that treaty-making was immediately undertaken with a steadfast mission to establish agreements modelled along British colonial policies. British policies, however, were rarely visionary and often were simply the result of immediate concerns. McNab (1983:100) argues that Canada inherited the "legacy of an Indian policy which

\footnotetext{
${ }^{18}$ The full title of the NWMP Act is An Act respecting the Administration of Justice, and the Establishment of a Police Force in the North West Territories. I discuss the NWMP Act and the NWMP in more detail next chapter.
} 
was regional in approach, was characterized by 'perpetual compromises between principle and immediate exigency, ${ }^{19}$ and which continually vacillated in its purpose and implementation." British policy centred on the formation of reserves based on presumptions about the eventual "amalgamation" of Indians, which colonial authorities believed would occur if the fur trade continued and if the position of the Hudson's Bay Company could be maintained (McNab, 1983:86).

As an extension of British Indian policy, treaty-making was seen by Canadian administrators and politicians as an orderly system of securing control in contrast to the Indian Wars in the United States (McNab, 1983). Unlike the development of the American West in the 1860s, British-Canadian colonial practices did not produce the wars and widespread vigilantism like those in America (Allen, 1983; Brown, 1970; Graybill, 2007). Although police forces such as the NWMP and the Texas Rangers were both formed in the early 1870 s with strikingly similar objectives to extend jurisdiction over outlying regions claimed by their governments, they developed dramatically distinct characteristics of enforcement (Graybill, 2007). Texas Rangers, in particular, were notorious for their acts of gratuitous violence that were supported by "a strong current of white racism" within Texas (Graybill, 2007:61). Similarly, white settlers in America were often encouraged to kill Indians in the interest of future white "peace, prosperity and progress" (Allen, 1983). Often these killers were hailed as heroes protecting innocent white women and children, and the widespread acceptability of pre-emptive violence towards Indians created much of the gunslinging culture of the American West (Slotkin, 1992). While mythologies of Canada's "bloodless revolution" are overstated, British-

\footnotetext{
${ }^{19}$ Here McNab refers to the words of Herman Merivale, permanent undersecretary of the U.K. colonial office from 1847 to 1860 .
} 
Canadian colonial violence was nonetheless pervasive, although considerably different in character and scale from practices in the United States. ${ }^{20}$

The standard template of British treaty-making invölved the demarcation of exclusive reserve territories for indigenous groups and provisions for annual annuity payments (Surtees, 1969). Unlike the earlier British treaties in North America, Canada's numbered treaties developed a unique character. The numbered treaties contained new items in addition to reserves and annuities. These commitments include the establishment and maintenance of schools, medical provisions, farm animals, implements and supplies, hunting and fishing equipment (see Carter, 1990: ch2). In addition to the encouragement of farming, Indians were told during treaty negotiations that they would not have their traditional hunting practices or mobility inhibited. They were also assured that the government would not interfere with their cultural or religious practices (Tobias, 1977). Taylor (1977) argues that archival materials - particularly correspondence between Morris and politicians in Ottawa - reveal that Indians were responsible in forcing the inclusion of these items into treaties. Ottawa was originally not inclined to include these items, but reluctantly agreed in order to finalize the deals. Scholars have noted that, at the time when the treaties were signed, Ottawa was especially ambivalent about implementing a broad governmental program to encourage Indian settlement and farming practices (see Carter, 1990; Dyke, 1986; Taylor, 1977). However, contrary to dominant historical accounts, it was originally the prairie Indians who sought to develop

\footnotetext{
${ }^{20}$ Similarly, Nettelbeck and Smandych (2010) have compared frontier settlement and pacification policies of Canada and Australia. Although there are significant differences between these programs, they argue $(2010: 357)$ that the "subjugation of prairie Indians - like indigenous people of Australia - was based on the negation of Indigenous sovereignty and the implementation of effective policies of containment and surveillance."
} 
agricultural economies. $^{21}$

Ottawa's weak commitment towards agricultural programs quickly became apparent. Politicians and administrators in Ottawa and Regina regarded many of these treaty provisions as privileges that could be withheld or revoked. Over the ten-year period following the treaties, promises were routinely ignored and rarely, if at all, did Canadian officials make good their obligations (Pettipas, 1994:63-85). While some efforts were made to fulfill the spirit of the treaties - the home farm program for instance - these efforts were poorly implemented, poorly designed, and cut short (Carter, 1990). ${ }^{22}$ Ottawa displayed its authority to displace and dislocate Indian groups in the prairies, but overall, they appeared inconsistent and uncommitted to implementing a program to enculture new practices of Indian conduct.

Perhaps the most significant element of Indian governance within the period following Confederation was, in fact, not explicit policy per se but the centralization of power within the Indian bureaucracy. ${ }^{23}$ In the 1870 s Indian Affairs was a branch of the Department of the Interior, which was created in 1873. In 1880, Indian Affairs became its own department but remained under the authority of the Minister of the Interior, who maintained the ritle of Superintendent General. The centrality of the National Policy depended upon the proper management of this portfolio and, from 1878 to 1883 , Prime

\footnotetext{
${ }^{21}$ The northern buffalo herds had disappeared by 1879 , and were completely exterminated as a basis of commerce and subsistence by 1883 (see Roe, 1970). The destruction of the prairie buffalo was largely a result of deliberate policy in the U.S. that aimed to starve the Indians, particularly Sitting Bull. ${ }^{22}$ Carter (1990) documents that Canadian Indian department officials were rhetorically committed to developing farming practices but government rhetoric rarely translated into sustained policies or programs. As opposed to assisting Indians who were willing to develop agricultural capacity, Carter demonstrates that officials with Indian Affairs was principally responsible for perpetuating the myth that Indians were unprepared or uninterested in agrarian life. To contradict these persistent myths, Carter (1990:36-40) details extensive agricultural practices in the Western prairies before the arrival of European settlement.

${ }^{23}$ Notably it was only in the 1830 s that 'Indian affairs' ceased to be a branch of the military, becoming a civilian branch of the British Colonial office.
} 
Minister Macdonald also acted as Minister of the Interior, taking personal responsibility for supervising the administration of the territories. Within the bureaucracy of the Department of the Interior, Carter (1990:50-51) writes that the Superintendent General rarely devoted any attention to the Department of Indian Affairs (DIA). The most influential Indian Affairs bureaucrat was the Deputy Superintendent General, who was tasked with overseeing all issues involving Indian Affairs in the West.

Lawrence Vankoughnet was the Deputy Superintendent General from 1874 to 1893. ${ }^{24}$ Vankoughnet epitomized Ottawa's centralization of authority and extremely frugal attitude towards economic spending, where an emphasis on settlement for white European's eclipsed any concerns for prairie Indians. Cuts to the model farm program, the curtailment of rations, and work-for-rations schemes, are the most prominent examples of Vankoughnet narrow-minded approach to the prairies during this period (see Carter, 1990; Dyke, 1986; Pettipas, 1994, Tobias, 1983). While these cuts were often justified by real financial concerns (Carter, 1990), the Indian Affairs bureaucracy often communicated these cuts as disciplinary measures. Inasmuch as these programs displayed biopolitical objectives, the DIA - as well as the Canadian government in general - would readily apply sovereign forms of power when they desired.

The political cultural that emerged from Ottawa contained an ignorant ambivalence to life or conditions in the North-West. Despite the power of the Canadian bureaucracy over the transformations taking place in the West, many Ottawa bureaucrats

\footnotetext{
${ }^{24}$ Vankoughnet was appointed by Macdonald in 1873 and, Leighton (1983) notes they shared a close personal friendship. Leighton (1983:104) characterizes Vankoughnet as an archetypal "Victorian Civil Servant." This is described as individuals with a frame of mind marked by a stern adherence to fixed standards, rigidity, earnestness founded upon a principled expression in the doctrine of hard work, narrowminded self-confidence, a high and serious attitude towards life's tasks, and indifference towards cultural differences. Leighton argues that much of the 1862-1892 period, the department was controlled by men who accepted Victorian ideas and standards.
} 
had never visited the prairies, and had no direct experience with its environments or people. Shewell (2005:24) characterizes the DIA as a distant and unaccountable entity:

[The Department of Indian Affairs was] a department isolated and unswerving in its task and methods. Relatively little non-government correspondence or outside interest impinged on the department's work, and the physical 'presence' of Indians was barely apparent. Indians were merely objects of an administrative mission; in keeping with their status as wards of the government, they simply were not heard.

Pragmatism, expediency, convenience, and thrift were the preeminent characteristics of the Indian Affairs department. This is mostly because the DIA, in concert with broader Canadian interests, were less interested in Indian matters than they were in the affairs of white settlers. The over-riding priority was a product of the National Policy and policies directed towards prairie Indians were simply by-products of broader government projects and desires.

Carter details how government officials, during the years following the treaty signings, regarded their concessions as charity and gratuities, rather than as legally required payments for land that was ceded (Carter, 1990:78). This paternalism was paralleled with an increasing perception of Indians as 'beggaars,' widely believed to be deserving of mistrust and fear. Persistent associations and stereotypes of Indian identities served to rationalize practices of control, which invariably aimed to isolate and monitor Indian populations. Precautionary measures such as policing and surveillance were regularly deployed as mechanisms of security. Commenting on late-modern manifestations of risk society, Lianos and Douglas (2000) uses the idea of "dangerization" to demonstrate how sensitivities to perceived threats create continuous defence mechanisms. The deployment of these continuous mechanisms aim to defend against perceived threats and, in turn, produce amplification effects where a proliferation 
of security mechanisms "perceive and analyze the world through categories of menace" (Lianos and Douglas, 2000:267). Dangerization as a process, in this sense, produces security mechanisms that operate in the present through a sense of anxiety about the future.

As products of suspicion and menace, responses to dangerization cannot be separated from social stratification, particularly the social identities that are associated with threats and anxieties. From its very beginnings, policing happened through various lenses of race, class, gender, and deviance, focalized by notions of dangerousness (Pasquino, 1991). In the context of the frontier, anxieties of white administrators and settlers amplified constructions about Indianness based on stereotypes and fears of nomadic, illiberal, and vengeful outsiders hedged against European civilization. As Lianos and Douglas (2000:269) write, "The projection of menace is at a small scale a defensive tactic but at a large scale it becomes a contemporary way of building institutional legitimacy. Danger-based legitimacy currently becomes part of normality." While the social context that Lianos describes as "contemporary" relates to a world of CCTV cameras, electronic monitoring bracelets, super automation, etc., processes of "dangerization" can also be traced to the transformations in the North-West. The "normality" that politicians, settlers, and police embraced in this colonial context was premised upon the assumptions of European civilization. Settlers also concocted oversimplified and prejudiced characterizations of Indians that became "selfperpetuating" (Fisher, 1977:91). Stereotyping defined Indianness, which would increasingly be infused with generalized characteristics of dangerousness and menace. The "fixity" of otherness ( Bhabha, 1994) also becomes part of colonial normality that 
fears an abstract other. ${ }^{25}$ In colonial contexts this induces calls for the regulation of Indians as a means to defend, on the one hand, the safety and security of the European population, while on the other, elements of the Indian population who are considered "good Indians."

The categorization of "good" and "bad" Indian, as I discuss below, is based on perceptions of docility and compliance to the agenda of colonial authorities. These perceptions are conditioned by long-standing stereotypes of Indians, as well as particular knowledge of threats that were produced through surveillance projects on the ground. Within colonial contexts, Bakhle (2010:52) argues that surveillance strategies problematize individuals and groups whose threat is far more rhetorical and symbolic than physical, as these forms of opposition question the fundamental legitimacy of colonial rule. ${ }^{26}$ As I detail below, the Canadian government actively pursued surveillance programs in the North-West in an effort to determine if "bad" Indians were conspiring to undermine the legitimacy of Canadian authority. The intelligence gathered produced forms of threats and anxieties that combined an abstracted dangerousness of the 'other' with discourses about criminality. Moreover it conflated political opposition - in the form of criticisms and demands about treaty obligations and relations - as threats to the fledgling Canadian order.

\footnotetext{
${ }^{25}$ Bhabha (1994:66) describes the "fixity" of otherness as an element of colonial discourse that acts on the ideological contruction of racial stereotypes. He describes it as a "paradoxical" and "ambivalent" form of representation that vacillates between a knowledge of what is rigidly "in place" and what is anxiously unknown. He writes that its "force of ambivalence" ensures "its repeatability in changing historical and discursive conjectures; informs its strategies of individuation and marginalization; produces that effect of probabilistic truth and predictability which, for the stereotype, must always be in excess of what can be empirically proven or logically constructed." Emphasis included.

${ }^{26}$ Bakhle's article addresses surveillance and suppression strategies targeting Indian nationalists opposed to British rule in the early $20^{\text {th }}$ century. The article focusses on the campaign against Vinayak Damodar Savarkar (1883-1966), an Indian law student committed to revolutionary armed struggle and charged under sedition laws.
} 
As evidenced by systems developed by the British in Rwanda and India, Lyon (2009) argues that early forms of surveillance programs in colonial administrations created systems for identification and classification. Similarly, Bakhle (2010:53) demonstrates that surveillance, as the "first weapon" at the disposal of colonial authorities, meant developing practices of state control that placed an increasingly large number of individuals under systematic monitoring. Monitoring strategies in the North-West often aimed to identify and categorize not only by proper name - Jim, Sarah, Cree, Eskimo, etc. - but by the characieristics of individuals and groups, often under dichotomous groupings such as "good" and "bad," "loyal" and "disloyal."27 These šurveillance practices are explicitly focussed on informing techniques of control. As Lyon (2009) notes, these early surveillance systems were integral for maintaining social order during periods of state formation.

Canadian authorities had limited abilities to practice surveillance on Indian populations in the early North-West. Relying mostly on Indian Agents and Farm Instructors, their strategy depended on Indians remaining on their reserves (Carter, 1990). As opposed to "active" surveillance (Marx, 1988), this passive strategy relied upon Indians coming to them. However, beginning in 1883 , the DIA developed an active surveillance program that involved infiltration efforts aimed at tracking indigenous leaders. The infiltration campaign discussed below involved a Métis trader named Peter Ballendine. His surveillance duties targetted suspected leaders of the movement demanding Ottawa respect its treaty obligations. This included men like Big Bear, Poundmaker, Little Pine, Little Poplar, Chief Beardy. However, Ballendine also targetted

\footnotetext{
${ }^{27}$ The categorization of Indians status was a central objective within the genealogy of Indian Act legislation (see: Bartlett, 1980; Miller, 2006; Milloy, 1991). Categorization practices reached the level of absurdity with efforts to institute the Eskimo disk list (see Smith, 1993).
} 
staunchly loyal chiefs like Mistawasis and Ahtakakoop. The covert surveillance did not produce panoptic transformations in the conduct of those surveilled, however the tangible knowledge produced through surveillance did help to shape the strategies and epistemes of those receiving the data. Most importantly, the knowledge gathered from the infiltration program of Peter Ballendine was vital in producing intelligence from spaces Indian camps, private meetings, etc. - that NWMP or DIA agents could not infiltrate. Knowledge of alliances, networks, populations, dispositions, and capacities of Indian threats mixed with settler fears of Indian dangerousness.

As I will discuss, Ballendine's surveillance records amplified perceptions of dangerousness through Canadian officials' selective interpretation of symbolic and rhetorical opposition to the treaty system as a criminal or treasonous conspiracy to attack settler society. While his reports speak to the balance of biopolitical and sovereign strategies of rule that are at-play in the frontier, they contribute - in concert with the Craig Incident, examined later in the chapter - to feelings of urgency held by Canadian officials. This in turn intensified efforts to develop mechanisms of security that could neutralize threats to the budding social order.

\section{Peter Ballendine: Surveillance \& Dangerousness in the Frontier}

Peter Ballendine was a Métis translator and former Hudson's Bay Company trader.

Although it is not clear when Ballendine began working for the Department of Indian Affairs, intelligence reports from his field work began appearing in October, 1884. It appears he was hired until July, $1885 .^{28}$ Stonechild and Maiser (1997:12) note that he acted as an interpreter during the Morris treaty negotiations, which might explain how he became so well-trusted by many Indian leaders. Over the course of his reports addressed

\footnotetext{
${ }^{28}$ A payment receipt from February 11,1884 , to July 11,1885 , totalled $\$ 375$. LAC RG10, 3705, file 17 , 936, Dewdney to Macdonald, November 27, 1885.
} 
to Indian Commissioner Edgar Dewdney and Assistant Commissioner Hayter Reed it is clear that Ballendine managed to ingratiate himself with his most prominent targets, Big Bear and Poundmaker in particular. ${ }^{29}$ Tobias (1983:540) notes that Dewdney believed that his most important staffing move during this period was the employment of Ballendine.

Ballendine's clandestine employment took place in the context of mounting tensions in the frontier. Dewdney and the DIA were aware of the growing animosity between Indians and the government, stemming largely from the non-fulfilment of treaty obligations. Over the course of his employ, Ballendine was constantly in movement, from camp to camp, reporting on the activities of Indians. His logs reveal that he made frequent trips, spanning hundreds of miles throughout the North-West, mostly circulating around Duck Lake, Fort Pitt, Frog Lake, and Carlton. Often times, Ballendine's reports take a narrative form, going through various Indians and contacts, listing their movements, actions and noting his own plans to continue surveillance activities. They often read as follows:

You can arrest [sic] assured that I will do my utmost to find out the movements as closely as I can. ${ }^{30}$

Beardy messanger [sic] I will follow him up and get to each camp as he leaves so that I can find out all he does and says. ${ }^{31}$

[Poundmaker] states that the Indians are sending tobacco from camp to camp, and should he hear what is going on he will tell me everything he hears. ${ }^{32}$

\footnotetext{
${ }^{29}$ Edgar Dewdney was Indian Commissioner from 1879 to 1888. See Titley (2009: 63-92). He also served as the Lieutenant-Governor of the North-West, which was as an executive position selected by appointment. The North-West did not have a system of representative government, which made Dewdney the head of government. Hayter Reed, who began in the North-West as an Indian agent in 1881, also became Indian Commissioner, serving from 1888 to 1893 See Titley (2009: 93-120). Next chapter I discuss the impacts of both Dewdney and Reed on Indian policy in more detail.

${ }^{30}$ LAC RG 10, 3582, file 949, Ballendine to Reed, October 10, 1884.

${ }^{31}$ Ibid., Ballendine to Regina (Dewdney) November 20, 1884.

${ }^{32}$ Ibid.
} 
Poundmaker stated to me the other day that Little Pine said as much as of he had made arrangements with the Blackfoot Indians to ceme here this summer and give us trouble... Jacob Red Deer stated also that Little Pine said that he reserve [sic] would be covered with Teapies this Summer. Little Poplar started out yesterday to the Stoney camp. I am going out today to find out what he is doing out there. ${ }^{33}$

Accounts of Ballendine's activities were conveyed to Regina, then often

forwarded to Ottawa, providing information on movements and diplomatic activity.

These materials could never have been accumulated through Ottawa's two primary surveillance resources: NWMP officers and DIA officials (Agents and Farm Instructors).

In addition to providing first-hand accounts from leading Indians, Ballendine also

provided the opportunity for the Canadian government to disrupt their political efforts. In this sense, Ballendine was not only tasked with surveillance but with a mandate to interfere with activities that Ottawa found objectionable. Dewdney explained these activities in a letter to Vankoughnet Ottawa,

Sir, I have the honour to forward here with [sic] a copy of a letter received from [...] Peter Ballendine whom I consider it was in the interests of the Department to engage in secret service against the Indians of the North, with the view not only of keeping the [...] advised of all movement but also of endeavouring to prevent a large gathering in the Spring. ${ }^{34}$

These orders to disrupt Big Bear's efforts to hold a pan-Indian meeting in the summer of 1885 were undertaken by Ballendine. In December, 1884, he reported:

I know that you could do some good and as you know I will only be glad to assist you all that $[. .$.$] in any power. I visited Big Bear again and will do all I can to$ prevent him to go down. ${ }^{35}$

It is unclear what precise actions were taken by Ballendine, aside from sowing confusion through discussions with these various communities. Some notes demonstrate

\footnotetext{
${ }^{33}$ LAC RG10, 3705, file 17, 936, Ballendine to Dewdney, January 2, 1885.

${ }^{34}$ LAC RG 10, 3582, file 949, Dewdney to Vankoughnet, December 5, 1884.

${ }^{35}$ Ibid Ballendine to Dewdney, December 26, 1884.
} 
that he believed he could persuade and coerce Indians to accept the undesirable terms of Ottawa's making. In a letter from November 20, 1884, Ballendine wrote,

I will stay sometime among Big Bear's People, and will do the best I can to prevent him to join these foolish Indians, and hope I will be able to do with him as I think I have done some good to Poundmaker by talking to him and explaining everything to him for his own good. I think if I mistake not that Poundmaker will again make a good Indian. He promised me in the name of God he will not interfere with any of the other Indians but only his own. If he proves himself to be a good Indian this season I only hope some small inducement be shown him during seed time. ${ }^{36}$

Reports from Ballendine, such as the one above, contributed to the Canadian government's long-standing categorization of indigenous people as either "good" or "bad" characters, depending on their willingness to accept the assimilatory and expansionist conditions of European civilization. As a loyal servant of the Crown, Ballendine clearly perpetuates these attitudes. For instance on October 10, 1884, he wrote,

Little Pine also states that as far as he knows Big Bear will not take his Reserve and that he is a fort Indian in some respects and a bad one in other respects. ${ }^{37}$

The term "fort Indians" refers to bands or groups of indigenous peoples that are forced to camp near European forts or outposts. Often forced to accept these locations as a result of desperation, and sometimes as a tactic or a method mediating difficult circumstances, these groups were continuously exploited and taken advantage of by those within the forts (Hall, 2003). The reference to a "fort Indian" underlines the notion that, from the perspective of government, docile and subservient Indians were to be considered "good," while those that refused - often at tremendous risk - to portray an outward display of docility were to be considered as "bad" Indians. The categorization of being a "bad" Indian often conveyed that these Indians were outright opposed to progress,

\footnotetext{
${ }^{36} \mathrm{Ibid}$. Ballendine to Regina (Dewdney), November 20, 1884.

${ }^{37}$ Ibid. Ballendine to Reed, October 10, 1884.
} 
civilization, or liberalism. In describing the NWMP characterization of Big Rib, or O'mukopi'kis, as "one of the worst characters" on the Blood Reserve, Dempsey (1998:71) argues that this meant he "scorned farming, clung to his Native religion, and displayed the arrogant independence for which his family had become famous." Actors such as these were considered hostile to Canadian authorities. Notwithstanding acts of disobedience, the vast majority of plains Indians were committed to agricultural production; many having long-standing practices of growing food (Carter, 1990). Contrary to depictions by Ballendine and Indian officials, most prairie Indians remained loyal to their treaty agreements (Dyke, 1986) and, despite assurances, Ottawa did not fulfill its obligations; this became the source of much of the animosity as well as despair and starvation within the North-West. Ballendine frequently reported on the poor conditions faced by Indian communities and, at times, empathized with their causes, particularly those groups that he identified as "good" Indians. For instance he wrote,

I think myself Poundmaker can be made a good chief [...] if he was treated differently. There must be some mistake or some misunderstanding between the parties. I know for my own part [...] I can handle Poundmaker as well as my own child and if I am not mistaking you will find him a different man next spring if I can only see him as often as I wish. ${ }^{38}$

Similar references are scattered throughout his letters, often times they are complimentary (albeit paternalistically) of Big Bear and Poundmaker. The only Indian he is solely cautionary towards is Little Poplar. As both Tobias (1983) and Stonechild and Waiser (1997) detail, the substantive elements of Ballendine's reports confirmed many of the Indian grievances that were at the root of discord in the North-West. ${ }^{39}$ However Dewdney and the DIA were selective in their evaluation of Ballendine's intelligence.

\footnotetext{
${ }^{38}$ Ibid. Ballendine to Reed, October 10, 1884.

${ }^{39}$ These grievarices are prominent in a number of Ballendine's early reports, particularly those from October 10, November 8, November 15, and December 26.
} 
This stems, perhaps, from their lack of trust in Ballendine. ${ }^{40}$ While their intelligence from Ballendine relayed a nuanced picture of the North-West and consistently reported on the poor conditions endured by Indian communities, colonial authorities only focussed on, and re-circulated elements of, the Ballendine reports that cast Indians as dangers. For example, Battleford Indian Agent Rae wrote to Dewdney on December 27, 1884,

I beg to inform you that Peter Ballendine reports that Big Bear will soon pay a visit here then go on to Duck Lake and Qu'appelle and that from what he can learn the majority of the band will go south in the spring; it was put to the vote but the few who are willing to settle down were over ruled by the majority. It is also reported that owing to Little Pine's visit south a good many Blackfoot intend coming South in Spring to assist the Indians here in their demands and that he Little Pine is very dissatisfied with the way this Band have been treated [sic] and the old cry that promises have not been fulfilled; this is of course idle [...] on his part as he has had everything he asked for in reason and has been especially well treated since his arrival here as his men from the first showed a disposition to work. $^{41}$

Reports of Indian grievances would typically become lost, or deliberately

overshadowed, by concerns over the laziness or general non-compliance of Indian

conduct. In particular, reports of the mounting pan-Indian opposition caused alarm in

Regina and Ottawa, as it was interpreted as resistance to the authority of the Canadian

government. Importantly, Ballendine's reports to Dewdney did not validate the DIA's

belief that Métis and prairie Indians were uniting for an armed uprising; in fact,

\footnotetext{
${ }^{40}$ It is unclear to what extent the DIA trusted Ballendine, despite Ballendine's record of crown loyalty. During one exchange it appears that the DIA had received or sought-after intelligence on his activities. In the P.S. section of a letter acknowledging receipt of one of his intelligence reports, Reed writes: "p.s. It would be well, when opportunities occur, to advise with our Agent and let them know anything that may be going on. I hardly think it is advisable that you should call meeting as at Frog Lake; will not the Indians suspect you are in the employ of the department? You should have conferred with [Indian Agent] Quinn while at [Fort] Pitt" (January 12, 1885). In response, Ballendine writes: "Sir, Yours of 12th instant [...] and contents duly noted. I see by your letter that someone [here's] reported to you that I called a meeting at Frog Lake, this I deny. I did once send for Big Bear before I left Frog Lake. I would [feel] much obliged to you if you will give me the name of the person who reported such" (January 31,1885 ). In a separate exchange with Dewdney, Ballendine defends his record: "I have been extremely cautious, and that the knowledge must have come to them from some other source. I may also state that I have been particularly careful in my intercourse with Indians" (Ballendine to Dewdney, March 19, 1885).

${ }^{41}$ LAC RG 10, 3582, file 949, Rae to Dewdney, December 27, 1884. -
} 
Ballendine explicitly reported the opposite. The Canadian government was fully aware that the threat of an Indian-Métis alliance did not exist (see Stonechild and Waiser, 1997:50-69). On the other hand, Dewdney was informed of negotiations and ongoing diplomacy with the Blackfoot Confederacy as well as among a number of woodland and prairie Cree bands. Regina and Ottawa were informed that at least 12 bands had committed to Big Bear's thirst dance scheduled for the summer of 1885 at the central location of Chief Beardy's reserve. While the rumours - although in large part unfounded - of an Indian-Métis alliance were cited as concerns by Ottawa/Regina, colonial authorities remained especially focussed on the actions of leading Indians who advocated the re-negotiation of treaties. Ballendine's documentation of the actions and activities of these Indians were central in Ottawa's approach to Indian matters during this period.

Beginning in the early 1880 s, Dewdney began to advocate a policy of "law and order" to crack the determination of Indian leaders. A central element of Dewdney's plan involved deposing chiefs that he deemed uncooperative or arresting leading agitators, such as Little Poplar. He also advocated the assiduous use of criminal laws to control the indigenous population (Hubner, 1998). In a letter to Macdonald, Dewdney referred to the policy of criminalization as one of "sheer compulsion" (quoted in Tobias, 1983:534).

Ballendine clearly echoed these plans and his surveillance reports contributed to

Dewdney's resolve in using legal measures to disrupt the treaty renegotiation movement.

For example, Ballendine wrote to Dewdney,

Beardy cannot complain he has a pretty fair crop and gets good help. During my visit at his reserve I found every family had a fair supply of food. I would recommend that when the Indian Act comes into force to have some of these leading men put in the lockup to make an example of them. ${ }^{42}$

\footnotetext{
${ }^{42}$ Ibld Ballendine to Regina (Dewdney), November 20, 1884.
} 
Dewdney himself advocated the tactic of disposing Indian chiefs as early as 1883. ${ }^{43}$ Following several warnings from Ballendine about Little Poplar, ${ }^{44}$ Vankoughnet authorized his arrest. On January, 1885, he wrote to Hayter Reed,

I am [...] by the superintendent General to acknowledge the receipt of your letter of the 16th instant, and of the report enclosed therein from Mr. P. Ballendine, now in the employ of the Department, relative to Little Pine's communications with the Blackfoot Indians, and the proceedings of Little Poplar, whom you describe as the worst Indian you have to contend with, and on who is capable of advising the Indians to commit any overt act. I am directed by the Superintendent General to inform you that you should have Little Poplar arrested if there be sufficient evidence against him to warrant the same. ${ }^{45}$

In turn, this order from Ottawa was relayed to the field by Dewdney on February

5, 1885. He wrote to Battleford Indian Agent Rae,

Sir, It would appear that the Indian 'Little Poplar' is still a great disturbing element among the Bands in the Battleford and Pitt districts and I would accordingly state that if there be sufficient evidence against him to warrant it, he should on any contravention of the law be arrested. Do not however do so hurriedly or without feeling confident of his being found guilty. ${ }^{46}$

No arrest of Little Poplar took place, likely because within a month the Rebellion had re-aligned policing priorities of the Canadian government. However the materials gathered by Ballendine directly influenced the policing strategies on the ground. Hacking (1995) describes how the construction of categories produce the types of qualities and effects that they claim only to describe. In the colonial context of the North-West, these "looping effects" began with the identification of leading Indians. When surveillance on these individuals was produced, whether or not they were reported - as in the case of Poundmaker and Big Bear as cooperative, or "good" Indians - their movements and

\footnotetext{
${ }^{43}$ Tobias (1983:532) details how Dewdney used the threat of deposition and incarceration to thwart Piapot's efforts to hold a pan-Cree thirst dance during the Summer of 1883 .

${ }^{44}$ In letters from October 10 , November 19, and January 16.

${ }^{45}$ LAC RG 10, 3576, file 309 part A,Vankoughnet to Reed, January 27, 1885.

${ }^{46}$ AC RG 10, 3582, file 949, Dewdney to Rae, February 5, 1885.
} 
activities were problematized as suspect and dangerous. In the detailed reports on Little Poplar, Big Bear, Poundmaker, etc., the problematization of the Indian political leadership through Ballendine's surveillance project produced a number of conflations. When Ballendine's reports were looped through official networks in Ottawa and Regina, evidence of mounting political opposition - in the form of Treaty negotiations movement - affirmed Ottawa's prior categorization and presumptions about Indian dangerousness.

This looping effect also transformed generalized fears of Indian dangerousness concocted by stereotypes of otherness into particularized knowledge of Indian threat.

The looping effect of Ballendine's reports contributed to that aggregate perception - or imaginations - of dangerousness in the North-West. Through insinuations that "bad" Indians would influence and/or infect a broader population, Ottawa's mechanisms of security developed as pre-emptive strategies to contain potential dangers. As Castel (1991) notes, the notion of dangerousness can target individuals and populations with preventative strategies. ${ }^{47}$ Castel $(1991: 283)$ writes,

Dangerousness is a rather mysterious and deeply paradoxical notion, since it implies at once the affirmation of a quality immanent to the subject (he or she is dangerous), and a mere probability, a quantum of uncertainty, given that proof of the danger can only be provided after the fact, should the threatened action actually occur.

Castel's (1991:283) notes there can only be "imputations of dangerousness" that postulate about the possibilities between "certain present symptoms and a certain act to come." In the North-West these imputations were informed by knowledge and surveillance on the ground and mixed with the broader political-economic interests centred in Ottawa and Regina. Problematizations of Indians within this mix were

\footnotetext{
${ }^{47}$ Castel (1991) is focussed on the advent of risk, as a move away from dangerousness. This is clearly illustrated, as he demonstrates, in the medical sciences. Nonetheless, his notion of dangerous is of particular import to colonial spaces, and worthy of further scholarly reflection.
} 
amplified into forms of crisis by over-arching colonial rationalities, which produced generalized anxiety towards indigenous peoples. Prieto (2003) uses the term "liberalism of fear" to explain how anxieties of elites were used to justify tactics for governing indigenous peoples in Ecuador based on sublimated notions of race or race war. In the North-West, racial otherness was personified by those "bad" Indians, who would not adopt European forms of conduct and threatened to incite their otherwise "good" Indian peers. Ballendine's intelligence was interpreted in Ottawa as an indication that Indians leaders were roaming and conspiring against the Canadian government. In receiving these reports, colonial actors like Dewdney and Vankoughnet emphasized the role of "bad" Indians and considered them to be an infectious presence in the North-West. In concert with other evidence of mounting antagonisms, such as the Craig Incident detailed below and Indian Wars in the United States, these intimate field accounts from Ballendine amplified settler and governmental anxieties.

As anxieties peaked in the 1884 period, correspondence reports to and from Ottawa are increasingly framed around sovereign strategies of "law and order." Very few mentions within the files immediately preceding the outbreak address biopolitical techniques for addressing Indian conduct. While a contributing factor, Ballendine's clandestine surveillance reports were not, by any means, exclusively responsible for the increasingly sovereign and disciplinary orientation from Ottawa. Tensions had been escalating since the early period of post-1870 settlement in the North-West and the Rebellion resulted from these dynamic tensions. Like Ballendine's reports and the manner in which they were interpreted by the DiA bureaucracy, the Craig Incident was 
another conflict that exacerbated tensions in the North-West. ${ }^{48}$ As I will argue below, it demonstrates how tensions in the North-West - and the prescriptions for government actions - were framed by perceptions on the ground, as well as by government authorities in Regina and Ottawa. Following an examination of the records detailing the Craig Incident, I conclude with a discussion of how the proximities of colonial rule mixed imputations of dangerousness with particularized threats to the population. This resulted in the activation of mechanisms of security and practices of sovereign power that aimed to neutralize and eliminate perceived threats. Unlike the mythologies of Canada's peaceably inclined colonial practices, the Craig Incident demonstrates a moment where violence associated with practices of sovereign power is activated as an efficient method of crushing the pan-Indian political movement, itself perceived as a threat to the consolidation of colonial project of nation-building.

\section{The Craig Incident, 1884}

In mid-June, 1884, the telegraph wire flashed with a series of emergency reports from

Battleford. Indian Agent J.A. Rae in Battleford was notifying Regina that a conflict was unfolding at a thirst dance held on the Poundmaker reserve. ${ }^{49}$ One of the telegraphs sent to Commissioner Dewdney reads:

Lucky Man's men gave instructor Craig a severe pounding with axe handle. Five police unable to arrest them, Crozier searching with thirty men this morning. Big

\footnotetext{
${ }^{48}$ During the Rebellion, Ballendine was employed by the Ministry of Militia and Defence, within the Battleford Home Guards. It is worth noting that, during the infamous "siege" of Battleford, he acted as a representative of the settlers and meet with Poundmaker and the Crees. During the entire time, he was completely aware of the loyalties and peaceful inclinations of the Cree but refused to dispel the hysterical fears of settlers barracked inside Battleford (Stonechild and Waiser, 1997: 91-96). Indeed, he deliberately circulated misinformation to both sides. He also inaccurately reported to Canadian authorities that the Cree were hostile. Later, during Poundmaker's trial, Ballendine would have to confess under oath that he was aware of Poundmaker's peaceful intentions at Battleford and that he was aware that Poundmaker was there to meet Agent Rae in order to affirm his loyalties to the crown (ibid.). I discuss these events in relation to contemporary representations of the "siege" of Battleford in my Conclusion.

${ }^{49}$ Canadian authorities were aware of the planned thirst dance and were apprehensive towards it long before June, 1884. Tobias (1983:536) details how Dewdney and the NWMP had attempted to disrupt Big Bear from attending the thirst dance.
} 
Bear and Poundmaker defied police Give authority to arrest Big Bear, Poundmaker and ring leaders who are calling Indians from other Reserves for thirst dance. Answer at once. ${ }^{50}$

These events described by Rae are what have become known as the Craig Incident: a dramatic confrontation within the heightened tensions immediately before the outbreak of the Rebellion. ${ }^{51}$ The thirst dance was well attended. Canadian officials reported that Indians from "all the Reserves with the exception of the Stonies" were present. ${ }^{52}$ There were also French half-breeds who were considered representatives of Riel's movement.

In advance of the thirst dance it was already well-known that, due to his poor treatment of Indians on the reserve, Instructor Craig was not liked among the indigenous community. Tensions mounted when Indians pressed Instructor Craig for food supplies to feed the assembled guests. In response to requests for food rations, Craig boldly refused. In his post-script of the events, Agent Rae described that, upon the refusal of rations, one of Lucky Man's men picked up an axe handle and struck Craig several times about the body and arms until he agreed to give them food rations.

After supplying the food, Craig and a small company of white settlers retreated until the arrival of a NWMP detachment under the command of Corporal Sleigh, who arrived on the scene about a half an hour after the occurrence took place. The speedy arrival of the NWMP dispatch was a result of Agent Rae having already requested their support - in advance of his and Craig's interactions with the thirst dancers. Upon their arrival, the NWMP went into the camp of 94 lodges and attempted to arrest the man who struck Craig. They were immediately surrounded by Indians, where Poundmaker and Big

\footnotetext{
${ }^{50}$ LAC RG 10, 3576, file 309 part B, Battleford to Indian Commissioner, June 18, 1884.

${ }^{51}$ The events described below are largely reconstructed from four reports, all of which are written by Rae and Crozier (two each), sent to Dewdney. Turner (1950:59-67) offers dramatized version of these events. ${ }^{52}$ Ibid. Rae to Dewdney, June 21, 1884.
} 
Bear informed them that they would not allow any one to be arrested, and that they were prepared to fight if necessary. With such a large number of Indians crowded about Corporal Sleigh, it was reported that he then "prudently considered it better not to attempt the arrest" with his small number of men.

NWMP Superintendent Leif Newry Fitzroy Crozier arrived shortly after with further reinforcements, approximately 25-30 Mounties. Upon Crozier's arrival, he visited the medicine lodge with a small contingent of men to arrest the accused. Crozier was unsuccessful, ostensibly because Corporal Sleigh was unable to recognize the accused. "Failing to identify the prisoner," writes Crozier, "I returned to my camp, and on the suggestion of Mr. Rae the Indian Agent concluded it was best not to attempt the arrest until the conclusion of the "Sun Dance.",53 The NWMP retreated to DIA storehouses located a short distance from the thirst dance. Arriving at $11 \mathrm{pm}$, Crozier reports that they worked overnight to fortify the buildings in fear of an unprecedented assault. A state of panic prevailed throughout the countryside, with residents and nearby settlers joining the NWMP within the camp in fear of an all-out Indian War. Meanwhile Agent Rae had travelled to Battleford overnight to "seek out reinforcements." ${ }^{, 54}$ He returned the next day with a total of 86 men, including armed civilians, where "the rifles belonging to the volunteer company were given out and a home guard formed."${ }^{.55}$

Crozier ordered that the assembled forces await within their fortified position until the end of the thirst dance before advancing again to make an arrest. After waiting within

\footnotetext{
${ }^{53}$ LAC RG 10, 3576, file 309 part B, Crozier to Dewdney, June 22, 1884. In some instances Canadian officials interchange the terms "sun dance" and "thirst dance." Sun dance is a generalized term used for religious ceremonies practices by indigenous people in North America. Different nations, however, have distinct terms including thirst dance and medicine dance. The plains Cree use the term thirst dance. See Erdoes (1972).

${ }^{54}$ Ibld Rae to Dewdney, June 21, 1884.

${ }^{55}$ Ibid
} 
the armed camp for a day, a confrontation between the NWMP and the Indians unfolded on June $20^{\text {th }}$. The group of whites, slightly over 100 men, found themselves in a standoff with approximately 300 Indians, less than half of whom had firearms. Crozier and the leading chiefs engaged in a long negotiation. In his report, Crozier wrote that to enter into "a detailed statement of their complaints, which were numerous, and of all sorts, would be out of the place here." Regardless, he did note that they complained that Craig "had used them badly at different times" and that, during the events in question, Craig had not only refused to give a little flour to a sick man but had "shoved him (the prisoner) before he struck Craig.," under any circumstances. ${ }^{, 57}$

When the Indians refused to hand over the prisoner, Crozier "ordered up the troops.. ${ }^{58}$ Rae's account, certainly embellished, is worth recounting in detail,

These were immediately surrounded by the Indians, who numbered probably 200 warriors. Poundmaker taking the lead. He had nothing on but his brush-cloth, and was armed with a club, into which was inserted three butcher knives. Crozier then told his interpreter to lay hold of the prisoner, while he himself also took hold of him, and called for some files of men to assist. Then the Indians began pulling back the soldiers while others kept shouting out that now was the time to fire and that they were ready to fight. The police were of course ready to fire [...] and strange to say the elder men kept riding round telling the police and the young men not to fire. Poundmaker made straight for Captain Autrobus making a blow at him with his war club, saying: 'I will kill you now.' One of the men seeing Poundmaker's motion pulled Autrobus back and he escaped the blow. Poundmaker was immediately covered by 3 or 4 rifles. Seeing this he jumped on one side, and disappeared amongst the crowd. He and two or three others laid hold of a policeman who had got separated from the Column, threw him down, and took away his rifle, revolver, and belt. By this time they were on the move with the prisoner, the young bucks trying to ride over the infantry and provoking them to fire in every conceivable way, going so far as to get in amongst the mounted men and pricking the horses with knives in order to throw riders off. Had a shot been fired there would have been a hard fight. It would have been the

\footnotetext{
${ }^{56}$ Crozier to Dewdney, June 22, 1884.

${ }^{57}$ Ibid

${ }^{58}$ Rae to Dewdney, June 21, 1884.
} 
beginning of an Indian War, and where once commenced there is no telling where its horrors would stop...I said before the first shot would have been the signal for all the horrors entailed in an Indian outbreak, which would have fallen particularly upon isolated settlers and women and children. ${ }^{59}$

It is clear that elements of Rae's accounts are embellished, as Rae was known to be an alarmist (Stonechild and Waiser, 1997:92). The aggressions of Poundmaker were nowhere found in the sequence of events described by Crozier, who, nonetheless, describes a similar atmosphere of panic and disorganization. In a cavalier description of his actions, Crozier wrote,

The Indians by this time were intensely excited, and making the most thrilling and indescribably gestures, and noises. Some of the older ones, including 'Big Bear', shouting 'peace,' 'peace' - Craig in the meantime could not see the prisoner, he had hidden himself. I shouted to the Indians: 'Bring me the prisoner, or I shall arrest you all if we have to fight for it.' Shortly after 'Lucky Man' brought him to me, this was the first time I had seen him [the prisoner]. ${ }^{60}$

To the surprise of many settlers, the Craig Incident ended without bloodshed, largely due to the diplomacy of Big Bear. In the wake of the standoff, Rae and Crozier wrote detailed accounts to Commissioner Dewdney. ${ }^{61}$ Both Rae and Crozier stressed that Indian Agents and Instructors be given more "discretionary powers" in dealing with "their Indians." They both took issue with rigid policies developed in Ottawa and Regina, particularly the hard-lined approach to the work-for-rations policy advocated by the upper echelons of the political and bureaucratic leadership. Crozier, perpetuating the myths of the Indian work ethic, wrote to Dewdney,

It does not seem to me reasonable to expect a lot of pure savages to settle down and become treaty farmers all at once - or even within a few years - and even if they do not do much work for some time, it should not be considered extraordinary." 62

\footnotetext{
${ }^{59}$ Ibid.

${ }^{60}$ Ibid. Crozier to Dewdney, June 22, 1884.

${ }^{61}$ Crozier, not satisfied with one, wrote a second report and reiterated his conclusions.

${ }^{62}$ LAC RG 10, 3576, file 309 part B, Crozier to Dewdney, June 25, 1884.
} 
He advocated a loosening of the rations system, despite Dewdney's concerns over the high costs of feeding Indians. Crozier wrote,

The time has now come in my opinion to choose between the policy of conciliation and that of fighting them... My firm conviction is, if some such policy as I have outlined is not carried out, there is only one other - and that is to fight them, by doing so, the country no doubt would get rid of the Indian and all troublesome questions in connection with them in a comparatively short time, but, in changing to that policy, we must be prepared for the change - (settlers in the country should know that such a change is to take place, for they would suffer most in the case of an outbreak now). ${ }^{63}$

In the above passage, Crozier contrasts the historical tension between

extermination and integration, which represent the two poles of British-Canada Indian policy. In noting the possibility of getting "rid of the Indian and all troublesome questions" with them, Crozier echoes policies from the British colonial administration that contemplated means to eradicate the Indians altogether. As permanent Undersecretary of the British Colonial Office from 1847 to 1860 , Herman Merivale often expressed that a policy of "amalgamation" through the fur trade "is the only possible Euthanasia of savage communities" (in McNab, 1983:87). In fact, in 1841, Merivale put forward only four policy options to address the "Native Question": extermination, slavery, insulation, and amalgamation (McNab, 1983). In a manner similar to Merivale's, Crozier nonetheless advocated a policy of conciliation (with the long-term objective of assimilation). Similarly, Agent Rae concluded,

I do not think that Big Bear or any of the others are going to submit to be starved out, and there is no doubt that these men are particularly hard up. If on the other hand the Department are bound to stick to their present orders then full preparations should be made to fight them, as it will sooner or later come to this, if more liberal treatment is not given. ${ }^{64}$

\footnotetext{
63 Ibid.

${ }^{64} \mathrm{Ibid}$. Rae to Dewdney, June 28, 1884. Rae also wrote to his cousin, Prime Minister Macdonald, in the immediate aftermath of the Craig Incident: "It is nonsense to say to them that they must work or starve...
} 
In their dispatches to Dewdney, Crozier and Rae both call for more "liberal" treatment and more discretionary powers for agents. They also provide on the ground critiques of Ottawa's Indian policy and express their frustration with the orders from distant Ottawa. Rae, for example, warned that "although it is very easy to send orders from Ottawa... I think you will find that more discretionary powers will have to be given to agents or trouble will follow." ${ }^{, 55}$ However what Rae and Crozier refer to as "liberal" treatment, Indians would consider simply living-up to the commitments made during the treaty process. During the 1870 to 1885 period, Indigenous people in the prairies "watched as Ottawa deliberately and systematically violated its treaty provisions in order to coerce the Indians into adopting the government's plans for settlement rather than following their own" (Miller, 1989:171). Thus, the DIA deliberately contravened both the letter and the spirit of the treaties when it was clear that Inđians would not idly accept starvation. As noted by Crozier and Rae, the primary concern motivating their insistence on a reorientation of policies was the impact of potential Indian conflicts on settlement and development. Simply put, Crozier and Rae concluded that the government had two choices: to feed them or fight them. ${ }^{66}$

Crozier's and Rae's recommendations adopt rationalities that consist of strictly sovereign expressions of power, where the authority of the state - not individual norms of conduct - regulate the livelihood of the object population. Their recommendations,

The thing must be brought gradually... or trouble will surely will surely follow. Of course if it is the intention of the Department to follow out their Cast Iron Rules then full preparations should be made for an Indian War" (quoted in Stonechild and Maiser, 1997:61).

${ }^{65} \mathrm{Ibid}$. Rae to Dewdney, June $21,1884$.

${ }^{66}$ Stonechild and Waiser (1997:33-34) note that in an 1879 letter written by Lieutenant Governor David Laird to the Minister of the Interior used similar phrase to describe conditions in the immediate wake of the buffalo disappearance. Laird wrote that the government had three choices: "to help the Indians to farm and raise stock, to feed them, or to fight them." 
however, fell upon silent ears. Much like Dewdney and Vankoughnet manipulated surveillance information from Peter Ballendine, the aftermath of the Craig Incident involved a similar hardening of attitudes. Dewdney outright rejected criticisms of the current policy ${ }^{67}$ as did Vankoughnet. In defending the merits of the biopolitical workfor-rations campaign, Vankoughnet wrote to Dewdney,

Such discretion should be exercised most prudently as otherwise we shall have a repetition of the Fort Walsh management as regards these Indians, namely a big camp composed of all the idle Indians in the country being fed at large expense. ${ }^{68}$

The response above from Vankoughnet is exemplary for two reasons. First, his reference to "Fort Walsh management" underscores the emergent biopolitical rationality where Ottawa is (at least rhetorically) committed to re-construct the behaviours - as they perceived them - of Indian subjects. If Indians are to survive, goes the biopolitical logic, they must transform their conduct and become liberal, self-sufficient, hardworking, agriculturalists. Vankoughnet's reference to "Fort Walsh management" echoes the description of 'fort Indians' offered by Ballendine. However, what Vankoughnet communicates is a policy that moves beyond the comforts of docile bodies of "Fort Indians" towards the encouragement of new forms of conduct in the context of liberal government, focussed on developing "technologies of the self." This underscores how emergent biopolitical rationalities animated - at least rhetorically - the rationalities that Ottawa had about the Indian population.

The second noteworthy element is Vankoughnet's (and Dewdney's) willingness to ignore the recommendations presented to them by Crozier and Rae. They will not adopt a policy of conciliation, nor will they adhere - let alone consider - abiding by the

\footnotetext{
${ }^{67}$ Dewdney to [incomprehensive], July 4, 1884.

${ }^{68}$ LAC, RG 10, 3576, file 309 part B, Vankoughnet wrote to Dewdney, July 24, 1884.
} 
legal requirements as laid out by the treaties. By having implicitly rejected the suggestion of 'feeding them,' colonial administrators stubbornly adhered to prevailing policies and opted to manage any consequences, should the Indians prove unruly. This presents Vankoughnet and Dewdney's adherence to biopolitical strategies as dubious, if not deceptive. As scholars have noted (Carter, 1990; Buckley, 1992; Tobias, 1983; Dyke, 1986) Vankoughnet and Dewdney - as well as the Canadian government in general systematically undermined the potential to have working agricultural programs. Their commitment to these biopolitical endeavours were largely rhetorical, and were far from substantiated in actuality. No less than nine months after Vankoughnet's response, the Rebellion had begun. One year after Crozier's and Rae's warnings, Big Bear and Poundmaker were tried and found guilty for Treason-Felony (see Bingaman, 1975). By not allowing a policy of conciliation, which would only provide modest rations, Vankoughnet's insistence on the rigid enforcement of the emergent biopolitical program contributed to the likelihood of violence. Tobias (1983:520) notes that "Canada's principal concern in its relationship with the Plains Cree was to establish control over them, and Canadian authorities were willing to and did wage war upon the Cree in order to achieve this control." In choosing not to feed them, Ottawa instead decided that it would either let thousands of Indians die of starvation, or it would have to fight them.

\section{To Feed Them or Fight Them: Discussion and Analysis}

Vankoughnet and Dewdney are faced with the option to either 'feed them or fight them.'

In Foucault's terms, the choice between these two actions is framed within a governing rationality that corresponds to his notion of sovereign power and the authority to "let live and make die." Dewdney and Vankoughnet refuse these options. They reiterate strategy aimed at transforming Indian conduct, demanding they feed themselves or starve. 
Ottawa's stubborn insistence on policies aimed to transform Indian conduct were rooted in the widely-held belief that Indian communities were lazy, unwilling to accept agricultural practices, and opposed to the liberal rule of law (Carter, 1990). Fully acknowledging the potential for widespread starvation, they insisted on policies that aimed to transform Indian conduct and to reform the social-political order of the prairies. Despite their treaty obligations, Canadian colonial authorities refused to accommodate indigenous demands and insisted, rather, on maintaining their biopolitical project of population-transformation. Superficially, while their responses only addressed the possibility of Indians farming or starving, the authorities were fully cognizant that Indians could also resist these colonial policies, as well as the "fundamental legitimacy" (Bakhle, 2010) of colonial order altogether.

Correspondence from Ballendine and the Craig Incident demonstrates that, while it is impossible to trace a discursive re-orientation of colonial power from sovereign to biopolitical, colonial governmentalities do not demonstrate successive movements from one form of rule to another: they balance both biopolitical and sovereign power practices. In the lectures Territory, Security, Population, Foucault (2007) explores the emergence of biopolitical rationalities, stemming from classical formations of sovereign power that consolidated in Europe. Foucault $(2003 ; 2007)$ clearly argues that mechanisms of security are tied to the emergence of liberal governmentality in the eighteenth century and, he notes, these do not discount the utilization of sovereign and disciplinary tactics. Although elements of governmentality studies have often portrayed the steady movement towards increasingly advanced forms of governmental regulation, treating governmentality as a successive movement can obscure and neglect the continued exercise of sovereign (or 
disciplinary) technologies within colonial biopolitical orders. While Foucault himself has been critiqued for not developing implications of his governmentality framework specifically in relation to colonial spaces (Inda, 2005; Hussain, 2003; Venn, 2009), his fragmentary works do include an entry point to conceptualize biopolitics and colonialism nonetheless.

Stoler $(1995 ; 2002)$ notes that, while not appreciated by many scholars, Foucault identifies race and racism as the rejoinder between biopolitics and colonialism. Indeed, Foucault clearly demonstrated this when he explores the links of emergent biopolitics and colonialism in his 1976 lectures 'Society Must be Defended' (Foucault, 2003). In these lectures Foucault introduces the argument that race/racism emerged as a sorting and fragmenting function in the emergence of the biopolitical state. In a new political reality, where the power of sovereignty includes the control of life"as "an object and its objective," Foucault (2003:255) argues that the notion of the "break" establishes racial categories and produces racial discourses. In turn, these create "caesuras" and fragments the biological "continuum addressed by biopower."

As I've argued, Ottawa's commitment to emergent biopolitical rationalities was mixed. While the treaty system implemented agricultural programs to develop and expect modes of conduct, Ottawa failed to provide any meaningful support for these programs. Moreover, Ottawa perceived elements of Indianness as a "break" to categorize populations of Indians and delineate the "continuum addressed by biopower." For Ottawa, some Indians were a representation of dangerousness and were categorized as agitators as threats to the population. "Bad" Indians were seen as threats because their unruly behaviours could infect others. Hayter Reed expressed this sense of threat in a letter to 
Vankoughnet, when in reference to Little Poplar, he warned: "Little Poplar is the worst Indian we have to content with and is capable of advising the Indians to commit any overt act. ${ }^{\prime 69}$ Although Reed does not elaborate, these overt acts do not involve planting carrots, but harken to a general anxiety that those who are perceived as non-disciplinary actors threaten the health of the population-as-a-species.

Foucault's analysis of race and biopolitics helps in our understanding that the caesuras opened by the threat of "bad" Indians are addressed through mechanisms of security. Foucault posits that threats to the population must be neutralized or eliminated and explains that the reason these security mechanisms become activated is that the "enemies" who have to be done away with "are not adversaries in the political sense of the term; they are threats, either external or internal, to the population and for the population" (2003:256). Demonstrated by Reed's concerns over Little Poplar's ability to advise Indians to commit any over act, Indians are regarded as a particularly weak and susceptible group within the aggregate population. This places them on a lower threshold along the racial continuum of the population.

The "fixity" of otherness (Bhabba, 1994) produces settler fears about Indians in the frontier. In the North-West, perceptions of dangerousness were commonly associated with roaming, savage, Indians. Settler anxieties were rooted in the normalization of European-Canadian order, where Indianness could be interpreted as a threat to the settler population. While these anxieties were widely-held among the settler population, the rationalities of the Canadian governmental apparatus clearly defined Indians among the populations - although at a lower racial status. Moreover, "bad" Indians, such as Little Poplar are regarded at an even lower threshold on the racial continuum, to the point that

${ }^{69}$ LAC RG 10, 3705, file 17, 935, Hayter Reed to Vankoughnet, January 16, 1885. Emphasis added. 
they are strictly interpreted as a danger. However, in this sense, the danger presented by those Indians categorized as "bad" Indians was not approached as an external danger, but was represented as an internal threat to the population.

The categorization of "good" and "bad" Indians opens a caesura in the population that Foucault (2003:61) identifies as "the splitting of a single race into a superrace and a subrace." For Foucault, the gradation of race within the biopolitical field of the population prefigures the birth of "state racism." He describes State racism as "a racism that society will direct against itself, against its own elements and its own products. This is the internal racism of permanent purification, and it will become one of the basic dimensions of social normalization." Foucault's notion of state racism undermines a strict understanding of the colonizer/colonized dichotomy that is present in colonial studies. ${ }^{70}$ Among both the colonizers and colonized, hierarchies of race within a population can be categorized by how they are perceived as internal threats. This sorting function, argues Foucault, also is complemented by the killing function that targets internal enemies of the population, as it is constituted by a multiplicity of races and racial hierarchies that are regulated within the claimed political territory. Following this argument, Foucault (2003:256) argues: "racism is the indispensable precondition that allows someone to be killed, that allows others to be killed. Once the State functions in the biopower mode, racism alone can justify the murderous function of the State." A parallel can be drawn here to the North West circa 1884, where decisions by colonial authorities towards indigenous people could best be described by the epithet: "we will starve them or kill them."

\footnotetext{
${ }^{70}$ Mawani (2009) and Stoler (2009; 2002) both make this point explicitly. Their projects are completely devoted to the problematization of the colonizer/colonizer dichotomy by detailing hierarchies of racialization in B.C. and the Dutch Indies, respectively.
} 
Foucault observed in his initial discussion of biopower in the History of Sexuality (published in the same year as the 'Society Must be Defended' lectures), that entire populations "can be mobilized for the purpose of wholesale slaughter in the name of life necessity" (1980: 137). This means that biopower does not just foster life; it also routinely "does away with it in order to preserve it" (Inda, 2005:16). In the North-West "bad" Indians are constituted as an internal enemy, a threat to the population, and a subrace that threatens the integrity of its race and other races. In defence of the population, these Indians can be murdered. Meanwhile, European settlers received a host of government subsidization, and Indians were subjected to liberalism by force (and hypocrisy) while facing constant obstructions from the Canadian government. Still, Ottawa accepted widespread Indian starvation, which was only averted if - despite many barriers - Indians produced food agriculturally. Demarcated by the continuum of biopower, Indians were viewed by colonial agents as having lesser value. Not only was Indianness regarded as inferior, racial inferiority was also perceived as infectious to the broader population.

While it might appear that the biopolitical project that emerged from the National Policy to reform or induce liberal-European conduct was abandoned in lieu of sovereign power's violence, this chapter set out to highlight how colonial governmentalities conjoin elements of both strategies. Neither the Rebellion, nor the Craig Incident, should be construed as a reversal to exclusive strategies of sovereign power. These events illustrate how mechanisms of security, operating on the field of biopower, target internal threats to the population. As complementary strategies, these practices of frontier justice were the ordering functions that governed life and death in the frontier. 
The Rebellion, as I will discuss next chapter, offered an opportunity to erase the leadership of the pan-Indian political movement. Furthermore, it allowed a consolidation of power over the prairies that, while eliminating capacities for broad-scale Indian opposition, dramatically augmented its institutional capacities to govern the conduct of conduct. Meanwhile, categorized through surveillance, the "bad" Indians had to be eliminated within the new colonial reality. The next chapter not only sketches the Rebellion, but focuses on the early post-Rebellion patrol system. Ironically, although the consolidation of power over the prairie Indians seemed finalized, I demonstrate how settler anxiety only heightened in the wake of increased settlement and circulations of NWMP patrols. 
Chapter 3

Mounties in the Frontier: Circulations, Anxieties, Myths

This chapter focuses on patrols and practices of the North West Mounted Police (NWMP) through an examination of correspondence reports from the year 1886, the year following the Rebellion. The year 1886 marked the opening of the Canadian Pacific Railway (CPR) and, by many accounts, is considered the moment of symbolic (and practical) "opening of the West". ${ }^{71}$ Settlements and embryo towns were springing up along the lines of the CPR and the vast territories were the object of grand transformative projects. Within the advance of European settlement, indigenous people remained an inconvenient reality for settler society. Many bands were the victims of punishing sanctions from Ottawa, which compounded outbreaks of starvation, disease, and violence from settlers (Carter, 1990; Pettipas, 1994). ${ }^{72}$ Despite the relatively unthreatening capacities or intentions of indigenous people, European society was beset by the threats - whether real or imagined by the presence of indigeneity in the newly formed Canadian state.

\footnotetext{
${ }^{71}$ See Hill's (1967) monograph The Opening of the Canadian West: Where Strong Men Gathered. Hill offers a classic idealization of the rugged Frontier Man, epitomized by NWMP police officers, cowboys, and pioneers. It should be noted that Cross (1970) has detailed that forms of "frontierism" similar to Hill's (which borrow from American folklore) have not gained much popular or academic appeal in Canada. For texts specific to the NWMP and the "opening of the West" that followed the Rebellion, see Turner (1950), Hayden (1911), Stanley (1992[1936]), and Beahen and Horrall (1998).

${ }^{72}$ In the initial aftermath of the Rebellion, Dewdney ordered that the costs of damages sustained to settler property be paid by Indians. He commissioned an inquiry in order to account for the costs, as well as determine the bands responsible for payments. See the Rebellion Damages Report, RG 10, 3720, f. 22 , 897. In total, Dewdney seized $\$ 57,189.36$ from annuity payments, despite the Canadian government's role in dramatically exacerbating the violence. The total seized by Indian Affairs was a seizable amount of money, particularly if measured by current values. In the $1880 \mathrm{~s}$, land in Manitoba was about $\$ 1 /$ acre (see: http://www.mhs.mb.ca/docs/mb_history/21/riellandclaims.shtml). In 2006, the latest data available, land averaged \$664/acre (see: http://www.gov.mb.ca/agriculture/statistics/pdf/2006valuefarmlandbuildings.pdf). If we imagine that the $\$ 57,189.36$ had been invested in land in 1885 , that land would now be worth almost $\$ 38$ million $(\$ 37,973,735.04)$. My thanks to DT Cochrane for his assistance with these calculations.
} 
The correspondence examined below emanates from the forts, patrols, and outposts that were established and expanding through the North-West Territories following the Rebellion. The interlocutors included the politically-minded comptroller in distant Ottawa, the much maligned Lieutenant Governor of Indian Affairs in Regina, and the equally pragmatic and entrepreneurial detachment commanders in Prince Albert, Fort Macleod, Wood Mountain, Fort Saskatchewan, Alameda, and Maple Creek. Throughout these records, the authors express various anxieties, desires, and strategies that animate colonial practices to secure the North-West. Moreover, they articulate the practical expanse of frontier justice. Demonstrating that the workings of governmentality on a national scale are inherently and fundamentally spatial (Hannah, 2000), I demonstrate how strategies of patrolling territories results in the production of various knowledges; geographic, agricultural, militaristic, and racial. With the implementation of a comprehensive patrol system in the frontier territories, I discuss how the circulation of Mounties produces various forms of knowledge, including characteristics of the Indian population. In the context of the frontier, I demonstrate that it is precisely through circulation that knowledge of population is accumulated and strategies are deployed to domesticate and order the territories and populations of the North-West.

In Security, Territory, Population, Foucault (2007) discusses the notion of circulation in relation to territory. Departing from the work of Le Maitre ${ }^{73}$, Foucault explains how powers of rule are practiced through the governance of circulations. Foucault (2007:18) describes these effects of circulation as "a matter of organizing circulation, eliminating its dangerous elements, making a division between good and bad

${ }^{73}$ Le Maitre, Foucault (2007:22) argues, was the "first great theorist of what we could call biopolitics, biopower." 
circulation, and maximizing the good circulation by diminishing the bad." Foucault details how Le Maitre's bio-strategy of circulation was largely focused on developing an ideal governing strategy for emerging industrial cities of Eủrope. Hòwever, the notion of regulation of conduct based on the management of good/bad circulations is also applicable to frontier territories - as spaces in the process of becoming ordered. Foucault (2007:21) locates this process of ordering territory as the "milieu." He writes: "The apparatuses of security work, fabricate, organize, and plan a milieu even before the notion was formed and isolated" (ibid. emphasis added). In this sense, the frontier is a milieu to be ordered, and this ordering is constructed on knowledge of particular "natural" and "artificial" formations within the milieu. Foucault (2007:21) adds, "The milieu is a set of natural givens - rivers, marshes, hills - and a set of artificial givens - an agglomeration of individuals, of houses, etc." What Foucault emphasizes is the relation between knowledge of territory and knowledge of population. Circulation can agglomerate knowledge of these natural and artificial conditions within the frontier while also developing securitization mechanisms that are established to anticipate, contain, control outbreaks of perceived dangers.

What emerges from circulation, writes Foucault (2007:122), are ranges of forms, action and fields of practice that aim to steer individuals and collectives. The records detailed below illustrate how demarcations and inspections of space also contribute to the ways and means of governing indigenous populations. This also relates to the colonial construction of "Indian" subjectivities, which is central to the management strategies of colonial governmentalities (Scott, 1999). The regulation of "Indians" as a population is premised on knowledge accumulated through direct contact and governance practices. As 
I detailed in the previous chapter, Indians and Indian conduct is sorted and categorized by colonial administrators within a "good" Indian and "bad" Indian polemic. This sorting mechanism translates generalized anxieties about Indian dangers into particularized Indian threats, such as "war parties," "raiding parties," "thirst dances," etc. The circulation of NWMP officers through the frontier becomes the contact points that contribute to stereotypes of Indian subjectivity as well as produce new practices and characteristics of "bad/good" Indians. These circulations also provide surveillance and intelligence information on movements, habits, conditions, demands, and behaviours.

Following from the previous chapter, this chapter begins by contextualizing the broader circumstances within the North-West at the time of the Rebellion. This will include a discussion of the role and size of the NWMP as well as presenting an overview of some literature that details Indian-settler relations in the North-West. These details are addressed to introduce some of the prominent characters and provide a broader context for the patrol correspondence discussed subsequently. The correspondence records are divided into three subsections. First, I will detail records that pertain to the NWMP efforts to establish patrol routes. These routes were established for policing the trails, but included various forms of intelligence gathering technologies. They also form the circulations network that enables the mobility that underpins policing strategies of the North-West. Second, we examine the particularities of otherness within the frontier, specifically in relation to Foucault's (2003) notion discussed in the previous chapter of race as a "break" in separating groups within aggregate populations. The third section connects circulations and the separation of otherness with the identification of threats, which then become the basis of security mechanisms within the North-West. I detail how 
colonial governmentalities are constantly responding to unique dynamics of fear and anxieties that emerge from settlers and policemen in the North-West. The correspondence records revolve around the capabilities to regulate circulations and control dangerous populations. Various other strategies emerge to address perceived threats and, as our interlocutors demonstrate, these practices are often contingent, momentary, and fleeting. As I discuss below, circulations and the objective to consistently re-visit practices of regulation are central in developing colonial governmentalities. The conclusion explores how the settlement of the North-West developed policing powers to consolidate jurisdictional authority over the frontier.

\section{The North-West Mounted Police and the 1885 Rebellion}

The creation of the North-West Mounted Police was announced in 1873 with the objective of establishing "rule of law" through the vast North-West. ${ }^{74}$ As "agents of the National Policy" (Macleod, 1978), the Mounties were empowered as police, magistrates, soldiers and diplomats (Harring, 1998:263-271). The NWMP were the carriers of law and Western justice into these frontier lands. By the late 1860 s and early 1870 s some of the violence from the U.S. Indian Wars spilled into the Canadian prairies (Allen, 1983). At this time, rogue whiskey trading had become a thriving and unregulated economy on the Canadian-British side of the Boundary Line and violence associated with the whiskey trade began to cause concern in Ottawa. In 1870, the Canadian government tasked Lieutenant William Francis Butler of the British army to investigate and report on the conditions. At the conclusion of a three month tour around the Saskatchewan District, Butler reported that "without law, order, or security for life or property... robbery and murder... have gone unpunished... and all civil and legal institutions are entirely

\footnotetext{
${ }^{74}$ See Macleod (1978) for a detailed account of Macdonald's vision for the NWMP, including an analysis of vast correspondence archives of Macdonald and the initial leadership of the NWMP.
} 
unknown" (quoted in Allen, 1983:232). In response to Butler's report (and a subsequent mission by Colonel Patrick Robertson-Ross of the Canadian Militia in 1872), Ottawa passed the NWMP Act, known under its full title as An Act respecting the Administration of Justice, and the Establishment of a Police Force in the North West Territories in May, 1873.

Eva Mackey (2002:34) writes that the formation of "the North-West Mounted Police in 1873 , to act as a quasi-military agent of the government in Western Canada, is one of the most romanticized events in Canadian popular history." Similarly, Walden (1982:3) discusses the myth of the NWMP/RCMP as "a popular fabrication." These popular fabrications were mostly promoted by the NWMP themselves, or authors close to the Force who shared their "vision of order." The celebration of the settlement of Western Canada is rife with depictions of noble policemen on the rugged, wild, and barren prairies (see Walden, 1982; Beahen and Horrall, 1998; Knuckle, 1994; Macleod, 1998; Morrison, 1985; Stanley (1992[1936]), Stewart, 1999 [1979]; Turner, 1950; Haydon, 1911; Wallace, 1998). These depictions also include the imagery of the Indian and, as Francis (1992:62) notes, within the "vast literature of the Mounties produced between 1885 and World War II, the Indian is the 'bad guy,' savage and ungovernable, a symbol of the dark forces of anarchy which had to be subdued before civilization could flourish in the West."

The narratives of noble policemen and savage Indians are captured throughout John Peter Turner's The North West Mounted Police, a widely-celebrated history of the NWMP. Turner (1950) was effectively the first NWMP historian and was granted full access to the Forces' archives. His two volume text continues to be cited as an 
authoritative history on the NWMP. ${ }^{75}$ Writing about the year 1886 , Turner (1950:267)

describes the impact of the NWMP on the frontier as follows:

Only 11 years had elapsed since Commissioner French's red-coated cavalcade had reached one of the wildest areas of the national domain. At that time savage tribes and calloused desperadoes appealed little as prospective neighbours to ranchmen or farmers. Yet within a period so brief as to be incredible, the movement launched in 1874 to establish law and order amid savage dominance had achieved its initial purpose.

Almost forty years after the release of Turner's history of the NWMP, official RCMP historians William Beahen and Stan Horrall (1998) re-visited the NWMP archives to update and expand on Turner's works. Their text, Red Coates on the Prairies, focuses exclusively on the period from 1886-1890. These are known as the "Herchmer Years," where the NWMP were under the leadership of Lawrence Herchmer. This post-Rebellion period is largely regarded as the most critical time in the evolution of the Force in the "New West" (Turner, 1950:269; Beahen and Horrall, 1998:ix; MacLeod, 1998). R.C. Macleod (1998: ix), another RCMP historian, has claimed "it was this period that established the Force in the public mind as representing the best features of the merging Canadian confederation." More than anything, Beahen and Horrall's text is a celebration of the valiant Mounties and their benevolent leadership in transforming the frontier. Although they are careful to update language used by Turner, much of the underlying themes - and uncritical celebration - of colonial expansion are evident throughout the text. For instance, Part one of the two part book appears under the title "Taming the Frontier." It begins by stating that a "substantial number of Métis and Indian people in the West had

\footnotetext{
${ }^{75}$ Over the course of reading archival material, I had the luxury of consulting Turner's text to understand broader contexts that letters and reports happen to address. Within an old and somewhat scattered archive, Turner's broad and comprehensive grasp was very helpful to contextualize fragmentary information collected through correspondence. However, I should note that Turner's text uses a popular narrative form that does not contain any references or citations, making it extremely frustrating to use as a reference source.
} 
violently rejected the government's method of accommodating them in the new West" (1998:1 - emphasis added). Within this short opening sentence there are three dominant myths that speak directly to the Canadian colonial imagination. They include a) an allusion to savagery (contained in the title); b) its emphasis on accommodation and benevolence from colonial powers; and c) the treatment of indigenous nations as a homogenous population (in particular the twinning of Métis and indigenous people during the Rebellion). I will examine the myths in turn.

First, while Beahen and Horrall avoid Turner's prolific use of synonyms for "savage" to describe indigenous peoples', the use of "taming" in the chapter title insures a continuity between these contemporary texts and those of an older (more direct) lexicon. ${ }^{76}$ The implicit values of progress and European civilization that are conveyed through this imagery functions on two levels. It expresses the inferiority of indigenous societies in contrast to Europe (see Ladner, 2001), and it rationalizes an assimilationist agenda that is grounded in ethnocentric paternalism. As Macklem (1993:12).notes, these types of allusions present an interplay between similarity and difference that constitute the "rhetoric of justification that has legitimated the imposition of non-Native legal norms on Native society by the judiciary." These articulations are the methods that establish and maintain legal relationships of inferiority and dependence.

In parallel to the presentation of Indigenous inferiority, the second myth circulated by Beahen and Horrall is an embellishment of the benevolence of Canadian "law and order." In suggesting that the Rebellion was sparked by Métis and Indian people

\footnotetext{
${ }^{76}$ I make a special note of this because, in their introduction, Beahen and Horrall present themselves as contemporary liberals, who attempt to present a more politically correct text than that of Turner. They note that the term "Indian" is used throughout the book because it is used in the archival records. Beahen and Horrall (1998:2) stress that they mean "no slight in any way to Aboriginal people."
} 
because they "rejected the government's method of accommodating them," Beahen and Horrall place the fault on the victims of colonial violence. The promotion of "accommodation" erases the well-documented (and deliberate) mistreatment that was systematically developed by the Department of Indian Affairs. Importantly, accounting for these injustices is not a matter of revisionist history: as correspondence and media records of the period indicate, the Canadian government was purposefully dismissive of Indian grievances prior to the Rebellion (Stonechild and Waiser, 1997; Titley, 1999). In ignoring these less-than-noble accounts of history, paid RCMP researchers like Beahen and Horrall can take advantage of historical amnesia and paint the "taming" of the West in benevolent terms of accommodation.

Finally, Beahen and Horrall state that "substantial number of Métis and Indian people in the West had violently" resisted the Canadian government during the Rebellion. In their study Loyal Till Death, Stonechild and Waiser (1997) document that the NorthWest Rebellion of 1885 was not - as popular history would have us otherwise believe - a widespread uprising against the Canadian government. Overall, the Rebellion consisted of a small group of militants, led by Louis Riel. This group was distinct from a broader movement of leading indigenous chiefs - such as Big Bear, Poundmaker - who were aiming to establish a unified pan-Indian movement to press Ottawa on unfulfilled treaty obligations. With calculated determination, the Canadian government deliberately conflated the actions of Métis rebels and the peaceably-inclined indigenous groups in order to manipulate political conditions and punish indigenous communities, despite knowing that they largely remained loyal to the Queen.

Stonechild and Maiser argue that the notion of an Indian-Métis uprising has 
evolved into one of Western Canada's most persistent myths. The most problematic element of this myth, they argue, is that it assumes that the indigenous populations were uniformly supportive of Riel's rebellion. As these authors document, this is a fundamentally false understanding of the complex social relations in the North-West. The presentation of a homogenous Indian uprising is inaccurate and many indigenous people were not supportive of a war against the Canadian state, but were interested in negotiations to improve their bleak conditions. ${ }^{77}$ Stonechild and Maiser (1997: 1) write:

Several Indian leaders across the West came forward and solemnly affirmed their allegiance to Queen Victoria... Canadian officials, however, chose to ignore these declarations of loyalty in favour of portraying the 1885 North West Rebellion as a concerted, yet futile, attempt by the Indians and Métis to wrest control of the region away from the Canadian state. They were all traitors, united in an evil cause...

Inaccurate and deliberate portrayals of all Indians and Métis as conspirers in a sweeping rebellion was used to justify a number of restrictive and repressive measures used to punish bands in the aftermath of "the troubles." Documentary records indicate that the reports reaching Lieutenant Governor Edward Dewdney ${ }^{78}$ in Ottawa from the North-West created such alarm that Dewdney felt an immediate stand should be taken against all agitation - Indian and Métis alike (Titley, 1999: 65). Jim Wallace (1998: 190) has noted that the Department of Indian Affairs used the Rebellion as an excuse to

\footnotetext{
${ }^{77} \mathrm{Big}$ Bear, for example, was a long standing hold-out from federal treaty-making efforts, causing much displeasure among settlers and politicians. He was a leading advocate for an Indian alliance to force better concessions from Ottawa. In response to Riel's diplomatic efforts in late ' 84 , early ' 85 to join an uprising he is said to have responded they "should not fight the Queen with guns. We should fight her with her own laws" (quoted in Wallace, 1998: 10). Stonechild and Waiser, and Wallace, provide detailed explanations of the complexity and diversity of politics in the Territories.

${ }^{78}$ Edgar Dewdney, an engineer turned politician, was named Indian Commissioner in 1879 because of his ties to Prime Minister Macdonald, not because of any legitimate qualifications (Stonechild and Maiser, 1997: 34). He also held the position of Lieutenant Governor of the North-West, an executive position that made him the head of the North-West government. In a biography of Edgar Dewdney, Brian Titley writes that he does not consider Dewdney a great man or a nation builder. Rather, he writes, "I see him as a type a representative of that class of adventurer who saw in the western frontier an unprecedented opportunity for self-aggrandizement" (Titley, 1999: ix).
} 
impose arbitrary and harsh punishments on Indian bands, often discriminating based on those that were loyal and those that were not. In other circumstances individuals or bands with no involvement in the Rebellion were punished regardless (Wallace, 1998: 191). It should be noted that indigenous and Métis grievances extended much further back; however, the Canadian government was dismissive of these grievances prior to the Rebellion. Hayter Reed - known to many Indians as Iron Heart (Wallace, 1998: 22) claimed Indians had no real grounds for complaint. He believed that their agitation was an exclusive result of being stirred up by Louis Riel (Titley, 1999: 64). In the Eastern media, Iron Heart also went as far as denying starvation and other grievances existed (Wallace, 1998: 47).

Spurred by provocations of the Canadian government, Louis Riel and a group of supporters declared an explicit uprising against the Government of Canada on March 19, $1885 .{ }^{79}$ Reacting to the declaration of an autonomous "provisional government" by the Métis, Ottawa declared a siege against the "insurgency" by mobilizing Canadian field batteries, battalions, militia men, and police. ${ }^{80}$ The Provisional Government, on the other hand, demanded that the territory be evacuated by Canadian police and government officials, and surrendered to the newly formed indigenous authority, or "face a war of extermination." ${ }^{\prime 81}$

\footnotetext{
${ }^{79}$ The legacy and personality of Louis Riel is contested within settler, Métis, and indigenous histories. Contrary to the dominant historical representation of Riel, Stonechild and Maiser argue that the depiction of Riel as a champion of indigenous peoples', despite the widespread acceptability of this view, is not entirely correct. They note that from his writings a different portrait of Riel seems to indicate that many First Nations were correct in not supporting his cause. His writings show that he regarded Indians as simple, primitive people, who should be made to work "as Pharaoh had made the Jews work" (quoted in Stonechild and Maiser, 1997: 77).

${ }^{80}$ For an analysis and of Ottawa's correspondence accounts, see Silver, A.I. and Marie-France Valleur (1967).

${ }^{81}$ Canada. Sessional Papers, 1886, n.43, "The Queen v. Louis Riel," appendix (43h), 2, quoted in Stonechild and Maiser, 1997: 65; also quoted in Wallace, 1998: 69).
} 
Despite Riel's grand posturing, there was no unified Indian-Métis alliance, nor any real capacity to fight the well-armed Canadian military, NWMP, and militias. What emerges from the documentary record is that Ottawa embellished the crisis to solidify its control and authority in the North-West Territories. Stonechild and Waiser (1997:192) write that "Canadian authorities keenly appreciated that Riel's activities had handed them a club, and they were determined to use it to beat into the ground - once and forever - all remaining vestiges of Indian autonomy." In the post-Rebellion period, the NWMP expanded greatly to assume a prominent role in policing the expansion of settler colonialism. Following the Rebellion, the force doubled its size in one year. From the end of 1884 the NWMP numbered 557, and by the end of the Rebellion it counted a total of 1039 men (Wallace, 1998: 59, 193, 209). The NWMP emerge from the Rebellion as a central institution in the control strategies of colonial Canada. ${ }^{82}$ As the pre-eminent force of law in the frontier, the NWMP was not only a force to maintain control over a particular space, they were central to the enforcement of pass laws, the containment strategies of reserves, the dispersal (and non-dispersal) of rations and equipment, and the frontline enforcement of "law and order." ${ }^{.83}$ In this sense, the NWMP had a broad array of power and responsibilities. However, many of these actions - pass laws, withholding rations - were done in direct violation of treaty agreements (Harring, 1998; Wallace, 1998; Stonechild and Maiser, 1997). While the government used the Rebellion as an excuse to

\footnotetext{
${ }^{82}$ In the immediate period following the Rebellion the NWMP was singled out - mostiy through the political manoeuvring of General Middleton in order to deflect attention away from him - with vocal criticism for events before and during the Rebellion. Wallace argues they were initially "scapegoated" for errors in military strategy, which culminated in Commissioner Irving being fired by Macdonald (Wallace, 1998: 203).

${ }^{83}$ Detachment commanders in the North-West were also given magisterial powers. The central forts possessed jails and courts, regularly handing out sentences. These occurrences were frequently detailed in the Monthly Reports, and provided summaries of judicial business from the respective detachments.
} 
neutralize Indian social and political organization, rapid settlement and land theft combined with a climate of political oppression; all of which exacerbated tensions.

In the immediate aftermath of the Rebellion, numerous records indicate that rumours of an impending Native uprising alarmed police and settlers alike. Beahen and Horrall (1998:60) documented how, each spring for several years after the Rebellion, these rumours and innuendo circulated, largely without any basis or actual event to cause alarm. To this end, the NWMP developed patrol routes as an essential function to appease the anxieties of settlers and gather knowledge of the Indian population.

\section{Patrols and Lookouts}

The vast territory of the North-West was connected through networks of waterways and trails, that severed through elsewise near-impermeable territories of long grass (in the south) and dense forest ranges in the near-North and far-West. Aside from the $\mathrm{CPR},{ }^{84}$ the. NWMP principally used the trails to transport their materials (see Macleod, 1978). The CPR was also used to transport settlers - in ever increasing numbers - to the varicus villages scattered throughout the territories.

Correspondence records indicate that several detachment commanders initiated patrol routes beginning in the spring of 1886. In a letter to Commissioner Herchmer dated April 26, 1886, the commander at Fort Macleod, Supt. Neale, outlined the new patrol routes and responsibilities for his District. According to the outline, Fort Macleod located in the Southern region of the far West, immediately looking over a number of reserves including the volatile Blood Reserve - would be a central hub of the patrol routes. In the outline issued to patrol leaders, Neale discussed the responsibilities of these

\footnotetext{
${ }^{84}$ For an account of the role of the railway in the 1885 Rebellion see Beahen and Horrall, 1998. As opposed to the Rebellion of 1873 , when the railway was not complete, the suppression of the insurgency in 1885 was accomplished with much greater military efficiency and brutality due to availability of direct rail travel.
} 
outings. After noting the safe keeping of horses, and general timelines for travelling, Neale wrote, "You will keep a sharp lookout for and examine all parties passing in the vicinity of your Post," adding, "Your principle duties will be to identify and intercept the passage of any party or parties driving horses ... who cannot give a strictly satisfactory account of $[\ldots]$ supported by documentary evidence." ${ }^{95}$ It should be noted that those without documentary evidence are likely Indians, but could also include bootleggers. In order to be more specific, Neale adds: "You will observe and record the movements of all Indians and Half-Breeds $[\ldots]$ and generally every occurrence which you deem of a suspicious or unusual nature. ${ }^{~} 86$

In a separate letter to the Commissioner, Neale reveals that patrols are strategically deployed in order to accumulate intelligence information on nearby reserves. In describing a separate patrol route to the Commissioner, Neale writes, "Another patrol would every day move round the south side of the Blood Reserve and watch the various river crossings. ${ }^{~}{ }^{87}$ Similarly, in a document titled "Instructions to Non-Com'd Officers in Charge of Patrols," the sub-commander of Wood Mountain detachment instructed officers to "collect all possible information with reference to the disposition and movements of the half breed and Indians on both sides of the line. ${ }^{.88}$ Patrol routes are not simply a matter of protection, they are actively engaged in what Baumann (2002) would call "reconnaissance battles." Patrols are deployed, in this sense, as methods of accumulating intelligence about subjects in the frontier. As Foucault (2007:45) explains,

\footnotetext{
${ }^{85}$ LAC, RG 18 1045, f. 110, Neale to Herchmer, April 26, 1886.

${ }^{86} \mathrm{Ibid}$.

${ }^{87}$ LAC, RG 18 1045, f. 110, Neale to Herchmer, April 12, 1886.

${ }^{88}$ LAC, RG 18 1045, f. 110, Wood Mountain to Herchmer, May 5, 1886. The mention of "the line" is in reference to the Boundary Line with the United States. It is worth mentioning that Canadian authorities would regularly attempt to gather intelligence on the U.S. side of the border. Correspondence reveals that the frequency in which Indigenous peoples' travelled across this artificially imposed line was of great frustration to NWMP officers and Indian agents.
} 
"security therefore involves organizing, or anyway allowing, the development of everwider circuits." Patrols as mechanisms of security are directly related to the notion of a space where reconnaissance is constantly responding to transformations and unexpected events. The aleatory nature of patrols and space are merely temporalized inasmuch as they are constituted by "events, or series of events, or possible elements, of series that will have to be regulated within a multivalent and transformable framework" (Foucault, 2007: 20). These circulations thereby act to secure space momentarily and gather information. Expanding as "ever-wider circuits," they also expand capacities for regulation over natural and artificial fields, while re-acting to probabilities and exigencies that are encountered.

The emphasis on circulation as a technique of securitization is captured in an exchange of letters between Dewdney, Commissioner Herchmer, and the Ottawa-based NWMP Comptroller Fred White. These letters debated a request by Red Deer River residents for the establishment of a permanent detachment and the strategic concerns of the NWMP's in the frontier. In one exchange, Dewdney notes: "I feel the stationing of the small detachments of police permanently at isolated points cannot conduce to the security of the districts, and must interfere seriously with the training and discipline of the Force." 89 Clearly Dewdney is responding to the new realities of the frontier. The emphasis on circulation is distinct from previous colonial rationalities within the NorthWest, particularly the outpost strategies utilized by the Hudson's Bay Company. Dewdney dismisses the notion of secured outposts as an adequate method of securitization. For Dewdney, mechanisms of security designed to circulate are new

\footnotetext{
${ }^{89}$ LAC, RG 18 1042, f. 95, Dewdney to White, January 9, 1886.
} 
strategies that do not merely sit and protect parcels of territory, they must be mobile and expansive in order to assert jurisdiction over the population and territory.

The selection of patrol routes also required knowledge of human and geographical conditions. These locations for reconnaissance are subject to change, depending on what information is accumulated through previous patrols and circulations. In another letter to the Commissioner detailing patrol routes, Neale wrote, "I decided to place a detachment at Bulls Head at the second crossing of Peigan Creek in addition to the one at Forty Mile Coulee; as the former place is one of the best 'look out' points on the road. ${ }^{\prime 90}$ Patrol routes would generally take several days, resting at various outposts that were selectively positioned at encounter points, then continuing along for many miles.

Despite the calculated efforts of NWMP to gather information through their circulation networks, these patrol routes often reported very little activity and seemed to produce very little intelligence accumulation. One could likely infer that indigenous peoples, unless they were travelling with carts and possessions, did not travel through the Canadian trail system but had their own mobility networks. ${ }^{91}$ When contact with Indians or Métis are recorded (and they are mostly with Métis families), they are described similarly to this entry:

Five families of half breeds from Indians Basin have passed through Willow Bunch lately on their way to Turtle Mountain U.S. they were detained five days, the names of the heads are... ${ }^{92}$

\footnotetext{
${ }^{90}$ LAC, RG 18 1045, f. 110 , Neale to Herchmer, April 30, 1886

${ }^{91}$ There is no indication of the NWMP having any knowledge of these systems within the records I have examined.

${ }^{92}$ LAC, RG 18 1045, f. 110 , Wood Mountain patrol to Herchmer, June 8, 1886.
} 
Another typical example, which accounts for their goods and comments on their disposition, was noted in a Monthly Report by commander Perry of Prince Albert detachment. He wrote,

On the 23rd we saw a party of Sioux Indians from the Pipestone + Oak Lake Reserves. It consisted of 11 men, 11 women, + several children. They had with them 9 lodges, 9 ponies, 1 colt, 1 mule, 1 ox, 4 carts, 1 light wagon, [...]. They stated that they intended following [sic] the Souris Valley for the purpose of hunting. One of the men - Aotia - had a fire-arm permit from the agent of his reserve. Their general appearance was quiet and orderly. ${ }^{93}$

More often than not reports indicated that there was no contact during the patrols.

They often included entries such as "patrol reports all quiet," and "no parties during my tour of duty." One revealing entry from a patrolman named Constable Gordon to commander McGibbon of the Alameda detachment stated: "I met no parties other than settlers during my patrol."94

In these discussions; Indians and Half Breeds are both implicitly and explicitly targets of the intelligence and control strategies. As perceived dangers, they represent an untrusted otherness that necessitates the deployment of these patrol routes that circulate in efforts to monitor and control the frontier territories. A May $29^{\text {th }}$ request from Lieutenant Governor Dewdney to Commissioner Herchmer reveals a dominant perception of Indians and the objective of NWMP patrols. He writes,

[O]ur Agent on the Blackfoot Reserve reporting [sic] that a number of his Indians have left the Reserve with some Cree lodges and gone to the Red Deer ostensibly for lodge poles and to hunt antelope ${ }^{95}$ and to say that it would be well if patrol parties were established as suggested by Mr. Begg [Indian Agent] for the purpose of watching the movements of these Indians and for the protection of the settlers. $^{96}$

\footnotetext{
${ }^{93}$ LAC, RG 18 1044, f.108, unnamed patrol report to McGibbon, September 25, 1886.

${ }^{94} \mathrm{LAC}$, RG 18 1044, f. 108, Gordon to McGibbon, October 12, 1886 (emphasis added).

${ }^{95}$ The letter actually contains the word "caribou" clearly scratched out with "antelope" scribbled above.

${ }^{96}$ LAC, RG 18 1045, f. 110, Dewdney to Herchmer, May 29, 1886.
} 
The letter explicitly connects the protection of settlẹs against the threat of "his" Indians, but the most stirring aspect of the letter is the assumptions and generalizations about Indian behaviours. Dewdney writes they are "ostensibly" leaving to gather supplies or hunt, seemingly unconvinced of their true motives despite full knowledge of the poor housing conditions and the widespread starvation facing these communities. Dewdney also assumes that the Indians in the area are a threat to the settlers, and not vice-versa.

Patrol correspondence records describe how circulations produce knowledge of terrain as well as observations on Indian conduct. Knowledge of the North-West geographies also enabled NWMP to improve the monitoring and surveillance of Indian populations who must be observed, governed, steered, and coerced. However, as aleatory series, encounters are sporadic and, despite their efforts to normalize and subdue, encounters (and non-encounters) can increase tensions in the frontier. Dewdney's knowledge of unmonitored Indians (cited above), in turn, resulted in calls for further monitoring and regulation of potential threats. As Foucault (2007:20) notes, "I think the management of these series that, because they are open series can only be controlled by an estimate of probabilities, is pretty much the essential characteristic of the mechanism of security." Patrols offer a visible presence of law and order. Additionally, they allow Canadian authorities to "watch the movements" of Indians and monitor for any indications of unrest. While the general sense of danger is omnipresent, patrols function to estimate and neutralize particular probabilities of threat. Discussed below are examples of how particular characteristics of these mechanisms of security are anchored in notions of Indianness that are amplified through circulations.

\section{Otherness in the Frontier}


Throughout the correspondence records examined, the interlocutors display a sense of management in balancing the strategies to regulate Indian populations. Detachment and outpost commanders, in particular, display an understanding of the political tensions and realistic appraisals of the policing capabilities of the NWMP within these colonial circumstances. Often, correspondence accounts display the disconnect between orders from Ottawa or Regina, and the realities that face NWMP commanders in the frontier. A letter from commander Perry in Prince Albert displays this type of frustration. He wrote,

At the commencement of the month a great many Sioux and Cree Indians were camped in the vicinity of Prince Albert. Instructions for their removal were received by Insp. [...] as early as the 15 th of June. Mr. [same] would not take the responsibility of remove [sic] them, so great was there [sic] without [...] the commissioner. $^{97}$

This letter illustrates how NWMP officers on the ground comprehend a separate series of realities than those issuing orders from Ottawa or Regina. For Commander Perry and the unintelligible Inspector at Prince Albert the application of jurisdiction is circumscribed by local and immediate limitations. Security, Foucault (2007: 47) tells us, "tries to work within reality, by getting the components of reality to work in relation to each other, thanks to and through a series of analyses and specific arrangements." In her extensive studies of the Dutch Indies archives, Ann Stoler (2009:39) has argued that "colonial governance entailed a constant assessing and recapping of what colonial agents could know and how they could know it." These include epistemological questions of rule, logistical challenges of jurisdiction, as well as the affective and emotive relations between oppressors and oppressed. As I detailed last chapter, the relations between Canada and the prairie Indians had deteriorated steadily since the signing of the numbered treaties. Colonial authorities were cognizant of these tensions and constantly

\footnotetext{
${ }^{97}$ LAC, RG 18 1044, f. 102, Perry to Herchmer, August 16, 1886.
} 
evaluated the potential of Indian (and to a lesser extent Métis) unruliness. Although these tensions existed following the Rebellion, the NWMP also imagined animosities and aggressions, which became reflected within the NWMP as a generalized distrust towards Indians. The bad faith practiced by the colonial authorities is especially important to note given that many tribes explicitly chose to pledge loyalty to the crown in the attempt to improve their extremely impoverished conditions (Stonechild and Maiser, 1997). Regardless of their confessed loyalty, mechanisms of security perceived these populations through a calculus of threat.

In a letter to the Commissioner, Commander Perry of Prince Albert detachment articulates the need for a policing strategy that recognizes and responds to the perceived untrustworthiness of Indians in the territory. Echoing Dewdney's distrust of "ostensible" Indian activities, commander Perry wrote, "The Blackfoot nation has been treated in the most liberal manner since their acceptance of the Treaty - far beyond what the Treaty demanded, but no one will say that their loyalty can be depended on." ${ }^{.98}$ In this letter Commander Perry, outlines a two-tier strategy for policing the frontier. He explained, "The safeguards against an outbreak are two. First, kindly and liberal treatment of all Indians and Half-breeds, and second; A well trained and powerful force ready to cope successfully with a sudden rising." 99 Perry's strategy can be characterized by the "carrotand-stick" approach to imperial sovereignty. While he expresses his general distrust of Indians, Perry goes onto list the legitimacy of many of their grievances, even suggesting that colonial authorities should make good on their Treaty agreements in order to make inroads and build trust. However, Perry concludes: "Of course even by the most liberal

\footnotetext{
${ }^{98}$ LAC, RG 18 1044, f. 102,, Perry to Herchmer, January 9, 1886.

${ }^{99}$ Ibid.
} 
treatment of the Indians I acknowledge and believe that the peace of the Country cannot be guaranteed." ${ }^{\prime 100}$ These sentiments from Perry reflect the Canadian self-conception as noble bearers of civilization and present the prairie Indians as potentially violent and irrational antagonists to the authorities. He also infers that, despite the "most liberal" treatment, the Indians cannot be completely trusted.

Perry's essentialism towards indigenous peoples' also carries discourses of "race war" or "state racism" discussed in the last chapter. These colonial notions of race/racism are founded in racial purity and the vilification of the 'other' (Foucault, 2003: 81). For Foucault (2003), state racism articulates the sovereign power's right to remove, contain and kill on the one hand, and modern biopower's obligation to make thrive under the principle of the sanctity of human life on the other. Race is central to the ability to order populations hierarchically, to reward and promote good conduct, and isolate or intervene upon bad or threatening elements of the population. Foucault (2003: 255) defines racism as follows:

It is primarily a way of introducing a break into the domain of life that is under power's control, the break between what must live and what must die the appearance within the biological continuum of the human race of races, the distinction among races, the hierarchy of races, the fact that certain races are described as good and that others, in contrast, are described as inferior: all this is a way of fragmenting the field of the biological that power controls. It is a way of separating out the groups that exist within a population.

Similarly, Goldberg (2002:110) has argued that racial states govern populations identified in explicitly racial terms. The legal and administrative identification of groups as inherently inferior or uncivilized invariably requires their management and oversight. As I discussed in the last chapter, colonial authorities mobilized the category of "bad" Indians to demarcate a subrace based on conduct - often imagined - that was antithetical ${ }^{100} \mathrm{Ibld}$ 
to settler colonialism. While other biopolitical strategies present breaks in populations abnormality (Foucault, 2003b), class (Rullac, 2010) hearing ability (Friedner, 2010), to name a few - race is central to biopolitical strategies (and sometime works in combination with other breaks) within colonial contexts (Moreton-Robinson, 2006; Stoler, 1995). Throughout the correspondence fragments of the NWMP, authors regularly refer to Indian conduct or subjectivities using terms like "nomads" or "infestations," or references to their "irresponsibility." In other instances Indians are loathed as non-civilized, averse to economic progress and hard work. There are also numerous references to the difficulties of enculturating agricultural practices to replace the (near exterminated) buffalo hunts. At the centre of discourses that emerge around " the Indian problem," are character faults that become objects for intervention. The forms of intervention discussed by colonial authorities oscillate between two poles: biopolitical strategies that aim to encourage and transform behaviours and practices, or sovereign strategies (mostly in the (uni)form of the NWMP) that aim to terminate behaviours and threats through forms of violence.

Colonial agents, however, do not always regard Indian subjectivity as homogenous. These authorities often try to differentiate and sort populations according to a hierarchy of conduct, distinguishing between "good" and "bad" Indians. In one Monthly Report, commander Grisbach at Fort Saskatchewan detailed a patrol's chase and subsequent confrontation with a series of accused horse thieves. He noted that "although we were unsuccessful in making any arrests the moral effect of this patrol was, as I have since been informed, most excellent. The good Indians being reassured and the bad ones 
intimidated. ${ }^{101}$ In his letter from January 9th, Prince Albert commander Perry details similar distinctions between the good and bad Indians and the nuance of governing populations. Perry wrote,

A liberal and considerate policy towards the Indians will tend to maintain the peace, which is so earnestly desired. If all grievances can be removed before the coming spring, half-breed agitators will not have that ground to work on - I say half-breed agitator advisedly. Although I consider the mass of the half-breed population to be quiet and peaceably disposed and, although I believe that the great majority regret the recent troubles, and will not repeat them hastily: still there are certain badly disposed men amongst them who, having a rankling feeling against law and order, will attempt to disaffect the Indians, and thus carry out their own schemes of revenge. ${ }^{102}$

Here, the half-breed Métis are distinguishable along a continuum of conduct, where only the "agitators" are the explicit source of threat because their potential influence over Indian communities. Perry is careful in his distinctions between these groups. A small group of Métis agitators are presented as central threats, however the underlying assumption is that, without liberal treatment, naïve and reactionary Indian communities present a more significant threat to the "desired" peace. Entries such as Perry's echo warnings examined last chapter that addressed Little Poplar and his ability to advise "Indians to commit any overt act." Blanket essentializations about the character of "Indians" lends evidence to Foucault's (2003:17) assertion that, beneath political power, are essentially "warlike relations." These sentiments reveal that the forced peace could be reversed quickly and, from the perspective of Canadian authorities, any violence is the result of the Indians and a small group of "bad" Indians or Métis agitators - not Canadian officials or settler expansionism. Despite the horrible conditions and illtreatment directed towards indigenous communities, Perry assumes that Indian

\footnotetext{
${ }^{101}$ LAC, RG 18 1044, f. 103, Grisbach to Herchmer, November 4, 1886.

${ }^{102}$ LAC, RG 18 1044, f. 102, Perry to Herchmer, January 9, 1886.
} 
communities are vassals to be influenced by "liberal" colonial treatment or an insurrectionary program of Métis rebels. Perry's letter expresses how Indians are characterized as irrational and inferior with little agency, while it is assumed that settler colonialism is a benevolent project that aims to protect and civilize.

Another unspoken assumption of Perry's - and others that mimic these sentiments in other correspondence - is that the violence that accompanies "law and order" is necessary, if not reasonable. Blomley (2003:124) notes the inscription of a frontier, which may be figurative, temporal and spatial, is integral to the process of law's expansion into territories deemed outside the jurisdictional framework of colonial authority. The effect of this expansion, argues Blomley, is to imagine law as rational, regulated, and rooted in common goals of the population. However, depictions of law as a rational and neutral entity clash with colonial perceptions of the frontier as "anomic or sectarian savagery beyond law's boundaries" (Sarat and Kearns 1992:5 quoted in Blomley). Throughout the correspondence records, rationales for mechanisms of security are based on perceptions of dangerous Indian conduct, conduct that lies outside European standards of comfort.

The letters and reports prepared by NWMP officials, however, rarely express outright fear. They are almost without exception proper, polite, and composed. To help understand the psychology of colonial actors, Guha (1997) distinguishes between fear and anxiety. Colonial actors experience fear, argues Guha, in response to particular threats, concerns, violence. Anxieties, on the other hand, emanate from abstracted dangers. They are more diffuse and do not have particular locations or sources. In turn, Hindness (2001:363) argues that anxieties therefore invite an "appropriate positive response - the gathering of more intelligence, a pre-emptive strike or the prohibition of 
a demonstration." As I examine in the following section, viewing Indians as irrational and dangerous gives rise to anxieties within settler communities, which include the ranks of the NWMP. These anxieties produced by constant perceptions and imaginations of indigenous dangers elicit increased calls for further "law and order," entrenching the regulatory machinery of colonial governmentalities that aspire to order the frontier.

\section{Settler and Police Anxieties}

Commander Perry sent a January $9^{\text {th }}, 1886$, letter to Commission Herchmer to detail preparatory plans for the NWMP in Prince Albert. In his letter, Perry describes the anxious moods within settler communities. He wrote,

I am glad to be able to say that the District is most quiet and the Indians peaceably inclined. At the beginning of the month rumours of Indian troubles, as you are aware, were circulated and believed in this place causing much alarm and excitement... The greater danger is the panicking state of the white population. ${ }^{103}$

In several instances, detachment commanders discuss intelligence reports that have been gathered during patrol missions. Intelligence is also gathered and relayed by entrepreneurial settlers that work closely with the NWMP in the frontier. These intelligence assets seem to rely mostly on rumours and second hand information. Reports are often recounted with great urgency, like this letter from the Moose Mountain Postal Office supervisor to the Commissioner:

Dear Sir, I would beg leave to draw your attention upon Indian Affairs here for a few moments, hoping that you may pay attention to it as those Indians here are getting fully prepared to make a break. There was an Indian [sic] told me the other day that the whites would get a bigger fright this spring than they ever got before." 104

The summer of 1886 passed without anything resembling the Rebellion of the previous year. Often the urgency of reported Indian threats fade away without being

\footnotetext{
${ }^{103} \mathrm{Ibid}$

${ }^{104}$ LAC, RG 18 1042, f. 95, Sup. John McEarchern to Herchmer, March 13, 1886.
} 
mentioned again. Stoler (2009:231) writes that rumours are largely shaped by the impressions and fears of colonists, rather than first-hand observation. Much like dangerousness (Castel, 1991), rumour registers what "people believed could have happened in the past and what could happen in the future." Stoler also describes (2009:231) how rumours prompt vague concerns for "peace and order," and demands for "judicial action and military reconnoiters." In the North-West, while rumours faded away, they were simply replaced with new rumours or suggestions of looming "war parties" and lurking, hostile Indians. These rumours were produced by a diffuse and constant sense of anxiety about the presence of Indians. In a report of an encounter between a patrol and a travelling settler near Wood Mountain, detachment commander Mclllree details another case of an imminent Indian threat. He wrote,

A french [sic] Canadian named Parent who came from Fort Assiniboine and has seen Little Poplar and the Cree Indians living there, reports that they threaten to come on Canadian territory and commit depredations. He passed through their camp and did not notice preparations to that effect being made, but a Cree woman who visited his wife told her that the Crees proposed leaving their families at Fort Assiniboine and come on [sic] Canadian territory as a war party to pillage. They stating [sic] that it was just as well for them to die by a bullet on Canadian soil as die of starvation on American territory. ${ }^{105}$

These cycles of rumours and threats reinforce the image of Indians as antagonists, thus precipitating more and more anxieties produced by the colonial imaginary. The NWMP are particularly active in creating these perceptions of Indian menace. Because their patrols are crafted with the intention of seeing and monitoring Indians, combined with the anxieties and conceptions of Indians as violent and aggressive, NWMP members seem to see Indian threats as quickly as they vanish. As an example of one of these

${ }^{105}$ LAC, RG 18 1045, f. 105, McIllree to Herchmer, June 8, 1886. 
encounters of the frontier imagination, Fort Macleod commander Neale discussed a patrolman's report about a mission to the outpost of Cypress Hills. Neale explained,

A Blood Indian report [sic] to Sergeant Brymner (Whoop Up) [outpost] on the night of the 4th that he had seen a lot of Indians on foot in a Coulle four miles from the post - who he thought were a war party of Crees. Brymner went out with his men and the Indian and made a thorough search of the place designated but found no trace of any Indians having been there, nor have they been seen since. ${ }^{106}$

Following the Rebellion, the NWMP were particularly concerned with a number of individuals that did not surrender and were living in the U.S. In particular the names Gabriel Dumont and Little Poplar are mentioned frequently. These leaders are targeted as especially dangerous. They are often seen or rumoured to be organizing future resistance. However, these rumours are invariably proven false. In June, shortly before Little Poplar was killed in the United States, Wood Mountain captain MeIllree wrote to the Commissioner and described these monitoring tendencies. He stated,

The detachment at East End Post kept up the weekly communication with Sup Gagnon's party, and received the report that Little Poplar and forty of his men were on this side, bent on mischief. Sergeant Smart, in charge of Detachment, came in to report, I telegraphed to the officer commanding at Fort Assiniboine and found that Little Poplar with twenty nine lodgers were camped close to that Post, and had no intentions, as for as known, of coming over this side. ${ }^{107}$

In the frontier, rumours and innuendo seem to be as fluid and mobile as war parties or raiding gangs. Despite the increased presence of NWMP patrols, the circulation of rumours and threats compound anxieties within settler communities and also within the NWMP. The most revealing correspondence from these records is a series of letters relating to a shooting incident near Cypress Hill, located between detachments of Wood Mountain (commander McIllree) and Fort Macleod (commander Neale). These records

\footnotetext{
${ }^{106}$ LAC, RG 18 1045, f. 110 , Neale to Herchmer, May 8, 1886.

${ }^{107}$ LAC, RG 18 1045, f. 110 , McIllree to Herchmer, June 9, 1886.
} 
express the vivid anxieties and animosity held by settlers and some members of the NWMP towards prairie Indians.

The first indication of trouble is contained in a very brief May $10^{\text {th }}$ letter to the Commissioner from Neale. It stated only: "a party of South Piegans Indians were pursued and fired upon by the detachment at Cypress." 108 Subsequently, on May $17^{\text {th }}$, the Sublieutenant from Regina, writing on behalf of the Commissioner, forwarded Neale's scouting report to Wood Mountain commander McIllree demanding a report on the incident. The letter signed "by order," instead of the standard "your humble servant," said, "You are requested to forward a report from the patrol as to the alleged firing on Indians." ${ }^{109}$ A response dated the same day by McIllree reveals the tensions in the deeper frontier zone. Mclllree wrote,

It is a great pity that we cannot shoot a few of their Indians: They are continually infesting these hills, and knowing as they do that we are not allowed to shoot them on sight, they are very bold and impertinary [sic] and give a great deal of trouble and arrogance to the Detachment: On dark nights they have continually tried to steal our horses, and it requires some prompt and [...] actions to keep them in check... The Indian Agent at Blood Reserve, in answer to a letter of mine, states there are quite a number of young men off the Reserve, and mostly composed of the bad characters. ${ }^{10}$

Over the course of a week Commissioner Herchmer in Regina forwarded McIllree's letter to Lieutenant Governor Dewdney, then to Comptroller White in Ottawa. However, over the course of the letters being forwarded across the county, descriptions of the incident begin to include the following sentence: "the detachment of Police stationed at the Head of the Mountain having fired on a party of Indians loitering in that

\footnotetext{
${ }^{108}$ LAC, RG 18 1045, f. 110, Neale to Herchmer, in a Monthly Report file dated June 9, 1886.

${ }^{109}$ LAC, RG 18 1045, f. 110, Deane to McIllree, May 17, 1886.

${ }^{110}$ LAC, RG 18 1045, f. 110, Mclllree to Herchmer, May 17, 1886. Interestingly, a small portion of this letter is printed in Beahen and Horrall (1998:62).
} 
vicinity." 111 This description differed greatly from the account of Corporal Bitchie, the patrolman that fired on the Indian group. ${ }^{112}$ Instead of an active chase, as described by Corporal Bitchie, the description in the NWMP correspondence was infused with the pejorative "loitering" to describe the Indians. This addition equates directly with forms of conduct, particular those of "bad" Indians, thus subtly justifying the violence undertaken by the NWMP. Interestingly, while Corporal Bitchie filed his report with Supt. Neale, it was only forwarded to the Commissioner and, as far as existing records indicate, was not parlayed past Regina. On May 20th, the Clerk in Council A. E. Forget replied with the following order to Commissioner Herchmer,

His Honor [Lieutenant Governor Dewdney] desires me to add that, in his opinion, unless quite certain that the Indians are foreign Indians, the Police should have considerable hesitation about firing, and even then only when the circumstances render it justifiable. ${ }^{113}$

Aside from the twisted assertion that it would be acceptable to shoot "foreign" Indians, the letter from Forget reveals the delicate peace and the apprehension on behalf of the government fearing Indian reprisals. ${ }^{114}$ This was echoed by an additional letter, the following day, penned by Dewdney to emphasize his disagreement with Mclllree's proposed aggressions. In that letter Dewdney stresses the importance of maintaining a commitment to legal processes, beginning with laying charges against individuals that break laws. These letters also initiate discussions about the use of Indian Agents to

${ }^{111}$ LAC, RG 18 1045, f. 110, Herchmer to Forget, May 19, 1886. Emphasis added.

112 Bitchie described an active chase between himself and several men on horseback, see: LAC, RG 18 1045, f. 110, Bitchie to Mclllree, May 8, 1886.

${ }_{113}^{113}$ LAC, RG 18 1045, f. 110, Forget to Herchmer, May 20, 1886.

${ }^{114}$ During this time, there are a series of telegraph communications between Comptroller White and Commissioner Herchmer about media reports in the East. The LAC files do not include the newspaper clippings, but indications given in the correspondence from White indicates that the media had dramatically sensationalized the story and enhanced the conflict and perception of an imminent Indian War. Comptroller White wrote, "Newspaper report that Police and Indians exchanged shots in Cypress Hills last week and one Indian killed [...], any report of this." In LAC, RG 18 1045, f.110, White to Herchmer, June 2, 1886. This type of sensationalism from the Eastern media was typical, particularly surrounding the Rebellion. See Mika (1972). 
transmit every noted instance of Indians leaving or entering Reserves. This discussion contributes to efforts to implement the reserve pass system and a coordinated method of intelligence sharing between Indian Affairs and the NWMP (see Barron, 1988). The pass system was first discussed in 1882 , however it was only implemented broadly in the aftermath of 1885 and, as John Jennings (1986:229) has described, it was the Rebellion that "brought the pass system to life with a jolt."

Dewdney's emphasis on the patient enforcement of laws and surveillance was not enough to satisfy Mclllree. After receiving Dewdney's reply and showing no interest in the stated plan to simply monitor the Indians, Mclllree sent another letter dated May $26^{\text {th }}$. His missive stated,

In connection with this I would beg to bring to your notice the constant annoyance that patrols in these hills suffer at the hands of these roving parties of Indians. They lurk around in the thickest part of the wooded Coulee's during the day times and at night come round the Camps and try to steal our horses. The parties are usually [...] Bloods and Piegans and they are very bold and impudent, they have stolen in the past a great many horses in this section of the country, killed stock, and murdered two white men, a half breed and an Indian. They are quite aware that we will not fire at them, except in self defence, which makes them bolder. From the nature of this country it is extremely difficult to catch an Indian, and I am strongly of the opinion that the time has come to use prompt measures with these marauders. The Country about here is setting up rapidly and a great deal of stock being brought in, and certainly tends to a feeling of insecurity that these bands of Indians rouse through the country. The Indians are ever ready to use their rifles and the settlers know this, and sooner than risk their lives, they will let the Indians take their stock without offering any resistance. ${ }^{115}$

In response to this letter from McIllree, Comptroller White wrote to

Commissioner Herchmer. The letter from Comptroller White stated,

The Hon. the Minister [Macdonald] to whom I submitted the correspondence has endorsed upon the same as follow: 'Supposed thieves cannot be shot down on sight.' I think it would be well for you to caution Supt. McIllree in this matter. ${ }^{116}$

${ }^{115}$ LAC, RG 18 1045, f. 110, McIllree to Herchmer, May 26, 1886.

${ }^{116}$ LAC, RG 18 1645, f. 100, McIllree to Herchmer, May 31, 1886. 
There are no further traces of correspondence on this account, and we can presume that the status quo prevailed. This account reveals how an incident of a stolen horse can be exaggerated into threats of marauding Indian bands, where agents in the field believe there is no alternative other than shooting Indians down on sight. In this case, Comptroller White and the political agents in Ottawa and Regina contained McIllree's desire for outward acts of aggression. This particular exchange exemplifies the convergence of anxieties and animosity in the frontier, and also reveals the limits of 'liberal' policies directed towards the regulation of conduct. What accompanies the movement of law and order in the frontier is an unspoken irony of colonial politics: its universalizing claims of authority are not universally enforceable. The fractured practice of colonial policing adopts much less universalistic actions than its rhetoric would expect. Mclllree's expression of this contradiction is similar to what Opitz (2011) defines as the liberal security paradox. Opitz argues that illiberal acts of violence can be justified when actors claim they are done in an attempt to establish or restore liberalism. McIllree, in this case, demonstrates this tendency. He seems perfectly content with abandoning the rule of law to summarily shoot suspected horse thieves, in the name of protecting "the Country." McIllree felt entirely justified with these suggested actions, and might have acted on his predispositions if it were not for the hasty sent cautions from officials in Regina and distant Ottawa.

Colonial authorities regularly legitimized their actions, if not their entire project, on the grounds of bringing civilization to savage, illiberal, backwards societies (see Wolf, 1997; Knafla, 2005). Yet, colonial practices are replete with accounts of illiberal violence. The violent response directed towards indigenous communities who had little to do with 
Riel's rebellion is an appropriate example of colonial authority willing to use extremely illiberal violence for the sake of establishing liberal order. This violence is justified by the need to neutralize or eliminate groups that are considered to threaten the prosperity and health of the broader population. Or, as McIllree put it, for "the Country." From the perspective of government, these illiberal actions are reasonable and acceptable only because they aim to promote future liberal conduct (Opitz, 2011). However, the response from Ottawa to McIllree demonstrates a continued emphasis on regulatory measures as a method of governing the conduct. The communications for Macdonald, White, and Forget express that, while marauding Indians are perceived as practising undesirable conduct, they are not encoded as a critical threat to the population. Unlike the violence that was justified against Big Bear and others for organizing political opposition to the treaties, individualized elements of "bad" behaviour are resolvable through efforts to reform conduct, particularly through education and labour training. Miller (1989:189-207) has referred to these post-1885 policies as those of "the bible and the plough." Moreover, training that aims at biopolitical transformations is supplemented by threats of criminal sanctions and disciplinary measures. Through more patrols, increased surveillance and circulations, the settlement of the North-West was cemented by these various mechanisms of security that targeted particular dangers but also remained in constant preparedness to safeguard the parameters of governing conduct.

As an effort to appease the anxieties of settlers, patrols also aimed to produce knowledge. Circulations accumulated knowledge that helped map terrain and categorized inhabitants. Territorial demarcations in frontiers, as John and Jean Comaroff (1991:89-90) argue, attempt to transform the "landscapes of others - typically seen by Europeans as 
wilderness before it was invested with their gaze - into territory and real estate; a process that made spaces into places to be possessed, ruled, improved, protected." In this sense, patrols from the NWMP and the application of "law and order" are securitization mechanisms that aim to transform the land and people of the frontier into rationalistic and peaceful subjects of the liberal imagination. Patrols provided comfort to anxious settlers, as well as providing a visible display of force to fulfill the Canadian government's assertion of jurisdiction. As circulations accelerated they produced further knowledge of territories, as well as constant observations of Indian behaviours. Moreover, patrols were central at discovering and imagining threats, thereby re-constituting the rationale for more circulations and precipitating a cycle of surveillance that aims to monitor and categorize potentially threatening elements of the population.

\section{Frontier Justice: NWMP Patrols, Law's Violence, and Mountie Myths}

In the North-West territories, the NWMP were the frontline agents in the expanding rule of Canadian authority. Turner (1950:304) notes in his monograph that the "patrol system had impressed upon Indians throughout the entire country that marauding parties would no longer be tolerated and that swift punishment awaited any found guilty." Although the racial hierarchies defined in biopolitical order are defined by the permanence of warlike relations (Foucault, 2003), police in the North-West were not engaged in typical warfare defined by columns, trenches, and garrisons. Antagonisms did elevate to that level during the Rebellion, yet the day-to-day policing practices were related mainly to the need of providing a sense of security for settlement. In this sense the apparatus of police is aligned to the larger regulation of political economy and the "state of prosperity" (Pasquino, 1991). While settlers in the North-West prepared for a state of prosperity, little concern was shared for the state of destitution experienced by prairie Indians. 
Nicholas Blomley (2003) has argued that European law - particularly in the forms of property, surveys, and grids - advances a violent system of exclusion and foreclosure. Although the language of property is banal, its effects are extremely violent. When Spry (1983) discusses the tragic loss of the prairie's "commons," she describes- in the period of two decades - the theft of the entire North-West land base. Although not forged exclusively through cannons and physical conquest, these transformations would have profoundly violent implications. However, in typical characterizations of the "New West" (NWMP, 1973[1989]; Stanley, 1992[1936]), violence directed down the biopolitical hierarchy defined by race/racism is considered secondary (if at all) to the benevolent advances of empire and the benefits of European "law and order." As Blomley (2003:121) explains,

This is because, of course, violence and law appear antithetical. Liberalism tends to locate violence outside law, positing state regulation as that which contains and prevents an anomic anarchy. The rule of law is deemed superior, given its ability to regulate violence in a civilized and humane way.

Similar to the McIllree exchange, where he is cautioned that Indians "cannot be shot down on sight," colonial authorities are self-imagined as humane and benevolent; where their actions provide a "vision of order" (Walden, 1982) that acts to protect both settlers and prairie Indians.

Benevolence is an especially prominent trope within Canadian policing history. Eva Mackay (2002) has described the character of the NWMP/RCMP in the Canadian nationalist imaginary as the "benevolent Mountie myth." She writes that the proliferation of this myth was integral to the emergence of the Canadian national identity at the turn of the century. Mackay (2002:77) argues that benevolent Mountie myth is based on the idea that the "process of civilizing the frontier occurred in a gentler, less violent, manner in 
Canada than the USA, because of British systems of justice, and, in particular, the benevolent and tolerant behaviour of the Mounties." The notion of Canada as a moderate, liberal and benevolent nation is deeply entrenched in contemporary imaginings of the Canadian self-identity. ${ }^{117}$ Reflected in the mythologies of "peacekeeping" and the "honest broker," these contemporized identities have a direct lineage to the NWMP mythologies produced in the early days of the North-West.

The period following the Rebellion witnessed widespread destitution and forms of legal and economic oppression directed against indigenous people (Buckley, 1992; Pettipas, 1994; Shewell, 2005). Canadian authorities consolidated power and, couching their actions in language of civilization and benevolence, undertook a dramatic program to re-form indigenous conduct. This included a mixture of industrial school program, punishing sanctions, renewed efforts at agriculturalism, increased policing, and the legal regime of the Indian Act. Although the experience of the Rebellion was strongly disciplinarian, post-Rebellion consolidation of rule perpetuated colonial governmentalities that advocated biopolitical strategies, backed by sovereign and disciplinary measures. The consolidation of rule that followed the Rebellion consisted of control over Indian subjects and, because of the circulations and aggregate knowledge of the NWMP, also included control over the territories identified for settlement. By applying control over these subjects and territories, Canadian authorities were able

\footnotetext{
${ }^{117}$ Police departments in Canada are the most vocal advocates of Canada's policing mythologies. Various agencies, of which the RCMP is the most active, currently participate in international missions to train and equip other police forces with Canadian "best practices." Currently, Canada has missions in Afghanistan, Sudan, Israel/Palestine, Haiti, to name a few. On a recent trip to Kabul, Toronto Police chief Bill Blair said: "I think something that is uniquely Canadian is the relationships we have been able to build our communities right across the country. It's part of the Canadian policing tradition to do community-based policing, where we work not in isolation from the people we serve, but in partnership" (Gerein, 2011). Academics have also supported the contemporary perpetuations of Canadian policing myths. For a recent example using Canada's involvement in establishing post-coup policing in Haiti, see (Kempa, 2010). For a critique of the Canadian Mountie myth, see Razack (2004).
} 
consistently apply "law and order" within the North-West and reconciled the distinction between sovereignty, territory, and jurisdiction. 


\section{Conclusion}

\section{Frontier Justice: Past and Present}

When it comes to the North-West Rebellion of 1885 , more ink has spilled than blood. Scholars have detailed how actual violence associated with the Rebellion was minimal, but the repercussions stemming from these events have been widespread. My thesis is a contribution to these works; however, it is a contribution that attempts to explain these repercussions theoretically. As I have argued, the colonial governmentalities that sought to order the frontier utilized both sovereign and biopolitical techniques of power. This is not meant to under-emphasize the widespread violence of colonialism. As Dean (2002) notes, "Sovereign violence, its symbols and its threat, is woven into the most mundane forms of government." Addressing how both biopolitical and sovereign techniques of rule are incorporated into the overall objectives of colonial governmentalities reveals the complex ways in which colonial regimes set out to conquer land and people. In particular, it demonstrates how indigenous populations are incorporated into the framework of national sovereignty, only to be coded internally as other, inferior, and abnormal.

Following the Rebellion, the policing and regulation of indigenous people was synonymous with settlement and Canadian prosperity. Indian policy in Canada maintained an overall objective of assimilation, while the "new authoritative game of justice" (Scott, 1995) was judiciously enforced throughout the North-West. Canada's history of wide-ranging and oppressive practices enforced through "legal complexes" (Rose and Valverde, 1998) are well documented. ${ }^{118}$ Colonial governmentalities spurred by zealous colonial agents combined an array of legal and extra-legal measures to isolate,

\footnotetext{
${ }^{118}$ In particular, see: Getty and Lussier, 1983; Hall, 2003; Miller, 1989; Miller, 1991; Pettıpas, 1994; RCAP, 1996.
} 
transform, and govern indigenous communities. Accordingly, the prominent NWMP presence in the North-West ensured that Canada's colonial framework of sanctions and rewards was backed by force. In consolidating their jurisdiction over these territories, colonial administrators during the post-Rebellion years had a variety of "mechanisms of security" that would facilitate the proper ordering of the frontier.

In Chapter Two, techniques of internal ordering were detailed through examining the infiltration program of Peter Ballendine. The undercover reports that were created by Ballendine offered Ottawa a glimpse into reclusive spaces that were mostly unknown to settler society. Information relayed by Ballendine also produced knowledge of Indian alliances, networks, populations, and dispositions. Moreover, the stream of information related to Indian movements, grievances, and political objectives created a "looping effect" (Hacking, 1995) that provided quasi-empirical justification for pre-established concerns about Indian dangerousness. Colonial authorities interpreted political resistance in the form of demanding treaty rights, as threats to the framework of the National Policy.

Examining the correspondence surrounding the "Craig Incident" reveals that racial otherness was personified by the category of "bad" Indian. As colonial agents like Crozier, Reed and Rae expressed, these were Indians that would not adopt European forms of conduct and threatened to incite their potentially "good" Indian peers. While colonial administrators viewed "bad" Indians as particularly troubling, they regarded all Indians as potentially dangerous. "Bad" Indians, as Reed described Little Poplar, were simply able to convince other Indians to "commit any overt act." "Bad" Indians were seen as especially threatening because they could infect others.

Serving as justification for interventions, the categorization of "good" and "bad" 
Indians opens a caesura in the population that Foucault (2003:61) identifies as "the splitting of a single race into a superrace and a subrace." In order to protect the prosperity of the population, this justifies the neutralization and/or elimination of potential dangers. In this sense, Chapter Two argues that within colonial states, categorized and sorted by racial typologies, biopolitical strategies can be more-or-less rhetorical in design. The commitments to reforming the conduct of "good" Indians or "bad" Indians can quickly dissolve into coercive and violent techniques of sovereign power designed to force widespread and collective change. While the colonial government had long maintained rhetorical commitment to biopolitical training, the farm program in particular, these commitments were sidelined by sovereign techniques that aimed to hastily enforce jurisdiction across the North-West territories.

In order to display how colonial governmentalities involve control over people and the control of territory, Chapter Three examined the circulation of NWMP patrols after the Rebellion. In establishing what Foucault (2007:21) called a "milieu," these circulations established a range of forms, action and fields of practice that aim to steer individuals and collectives. These patrol efforts were designed around the capabilities to regulate circulations and control dangerous populations. However, while these patrol routes were formed to appease settler anxieties, correspondence examined in this chapter demonstrates how the circulation of NWMP officers often resulted in new forms of anxiety. In most cases this was represented by an amplification in perceptions of dangerousness.

To demonstrate how anxieties of settlers and NWMP officers were amplified I focussed on a series of correspondence related to a minor incident of horse theft. Near the 
NWMP offices at Cypress Hill, in what is now the south-eastern border of Alberta, the incident which began as a theft quickly accelerated into a chase. Then a wayward shot was fired by an NWMP officer. Subsequently, this rather small altercation was the subject of rumour and exaggeration. Over the course of a week, the story of the chase had sparked media claims of an impending Indian War in the West. Moreover, it also setoff a series of letters among NWMP and government officials on broader issues of policing and policies of engagement. As I demonstrated, this was capped by the letter from commander McIllree from the Wood Mountain detachment who lamented that he could not "shoot a few" marauding, lurking, infectious Indians.

Mclllree's letter went as far as Prime Minister Macdonald, who cautioned against such actions. Government officials such as Macdonald, Dewdney, Reed, etc., continued to express their commitment to biopolitical strategies to transform - and assimilate Indian populations. Simultaneous to these affirmations of biopolitical techniques, colonial officials also advocated measures of sovereign power against individual Indians. This was most explicitly demonstrated by the trials and hangings that occurred after the Rebellion (see Waiser, 2009). In an act of "summary justice" (Beal and Wright, 2009:361), 81 Indian men were tried including Big Bear and Poundmaker (see also Bingaman, 1975). In total, 8 Indians were tried and hanged in Battleford by an all-white jury, before a prejudiced judge who advocated vengeance for the "siege" of Battleford, and without access to legal representation (I discuss the "siege" of Battleford below). These trials and hangings were explicitly vindictive. In Macdonald's words, the executions were to "convince the Red Man that the White Man governs" (cited in Waiser, 2009:474). ${ }^{119}$ However the only distinction between the violence of the trials and the

\footnotetext{
${ }^{119}$ Similarly, Reed wrote to Dewdney about the prospect of having a public hanging: "I am desirous of
} 
violence advocated by Mclllree was in the process and performance of punishment.

McIllree advocated vigilante justice, where he or others could wantonly dispense violence by virtue of their status as NWMP officers and the likely support of nearby settlers. On the other hand, the trials in Battleford were sanctioned and animated, however unfairly, by liberal discourses of trial and fair punishment. This process underscores the essential objectives of colonial governmentalities: to establish the conditions for settlement and prosperity within the framework of liberal, capitalist forms of governance. The violence directed towards aspects of the population that has been categorized as dangerous proceeds through codified and juridical processes. Criminal law was imposed on indigenous people of the North-West, particularly as a method of control and suppression (Hubner, 1998; Harring, 2005). The violence that accompanied the imposition of the legal regime was intended as a demonstration of both the superiority of Western norms and as an expression of fairness to be emulated by those that were forced into its game.

Finally, Chapter Three concludes by highlighting how the consolidation of rule following the Rebellion was a product of reconciling distinctions between sovereignty, jurisdiction, and territory. By enforcing the jurisdiction through these territories, the NWMP emerged as an integral institution to governing and enhancing the prosperity and health of the nation. The NWMP also emerged as a symbolic icon of Canadiana (Francis, 1992) and came to personify the mythologies of Canada as a moderate, liberal and benevolent nation. Indians, however, were encoded legally and symbolically as "children" to be helped, disciplined, rewarded and, in some cases, feared. Socio-legal would cause them to meditate for many a day" (quoted in Beal and Macleod, 1984:331). 
colonial apparatus in Canada also embodied themes of benevolence. Since the objectives of frontier justice are to order internal populations, the network of legal complexes in Canada are inscribed and designed according to the norms of settler society.

Abnormalities, therefore, are to be neutralized.

In this thesis I have combined a number of concepts to explain ordering practices of colonial powers. I've discussed the manners in which these strategies of rule - the colonial governmentalities - are produced to domesticate and transform the frontier according to the norms and desires of European colonial order. However, unlike simple military or policing objectives - such as capturing a fort or arresting a bootlegger - the process of ordering is continuous. Powers of regulation adapt practices and strategies based on contingent, changing variables. They operate in the present to pre-empt dangers that could effect the future. Frontier justice also involves racial categorizations that are inherently designed according to European hallmarks of social ordering, where certain populations are imbued with characteristics of dangerousness and otherness. As abnormalities to the norms of civility and conduct found in settler society (McWhorter, 2009), ordering processes seek to continuously govern and regulate these perceived dangers. However, these functions require more than the simple categorization of "good" and "bad." Detailing colonial practices in the Dutch Indies, Stoler $(2008: 359 ; 2009)$ has noted that "being a taxonomic state meant more than setting out categories." Categories are merely a filter in establishing forms of intervention and regulation. Moreover, in referring to more than simply categorization, Stoler details the centrality of sentiments and "affective states" held by European colonials in shaping the processes and practices of colonial rule. 
I argued in Chapter Three that, despite the power of colonial authorities, sentiments and anxieties pervaded colonial imaginations in the North-West frontier. The objects of these affective states were invariably Indians: Indian war parties, roaming Indians, Indian thieves, Indian uprisings. Following the Rebellion, threats of Indian violence dissipated slowly; only to be replaced with new Indian threats. Officials, settlers, and the media were continuously anxious over issues of Indian dependency, Indian women, Indian sexuality, Indian habits, in addition to requisite vinaigrettes of potential Indian violence. These affective states within Canadian settler society are the well-spring of legitimacy for frontier justice.

Ordering practices in the frontier are flexible and respond to the affective states and anxieties of settlers, who demand that dangerousness represented through stereotypes of Indians - stemming from what Francis (1992) calls the "imaginary Indian" - be regulated, policed, and controlled. Perceiving danger and disorder, colonial governmentalities aim to secure and regulate territories and populations. Frontier justice, in this sense, is a continuously unfolding process. However, these demands for regulation are not because the frontier is still an externally desired space for conquest. While frontiers might appear as spaces of otherness belonging to the external world, they are, in fact, representations of abnormality within a colonial order that understands itself as a homogenous space of sovereign authority. As a continuous process of normalization, practices of indigeneity that represent "backwards" or traditional eras are criminalized and delegitimized in the name of progress, and thereby subjected to mechanisms of security.

\section{Frontier Justice and the Colonial Present}

These practices of neutralizing Indianness are not remote or ancient history. The most 
singular feature of Canadian policy concerning Indians is that of "civilizing the Indians," which has shown almost no variation since the early $19^{\text {th }}$ century (Bartlett, 1980). Colonial ordering remains a contemporary reality, and Canadian efforts to assimilate and/or annihilate indigenous social order have a clear continuity to the opening of the West that followed the Rebellion. As the authoritative framework inscribed on colonial spaces, frontier justice is a continuous process of normalization. Canadian authorities are constantly tasked with monitoring and neutralizing marks of abnormality that conflict with the norms of the settler state. This is manifest in contemporary efforts to enforce "First Nations accountability," juridical decisions that trump Canada's "duty to consult" in the name of economic development (Delgamuuk, 1997; see Monture-Angus, 1999), dramatic overrepresentation of indigenous populations in prisons and jails, ${ }^{122}$ as well as continuous conflicts between Canadian police forces and indigenous peoples. ${ }^{123}$

Frontier justice is also evident in contemporary efforts to protect the "normality"

\footnotetext{
120 "First nations accountability" is a phrase used by Conservative/conservative groups that argue for Canadian oversight of Band Council finances. Band Councils are creations of the Canadian government made to facilitate payments of treaty, annuities, and transfer payments to First Nations. In 2010, Conservative MP Kelly Brock introduced a private members bill, Bill C-575, named the First Nations Accountability Act. The Bill was directly linked to reports issued by the Canadian Taxpayer Federation concerning the fiscal practices of First Nation Band Councils. Bill C-575 died on the order paper after an election was called in March, 2011.

${ }^{121}$ The first "modern treaty" was the Nisga'a Treaty, signed in 1999. As a framework for the modern treaty process, it has been described as a form of "mini-municipalism" (Abele and Prince, 2006) and allows private ownership of 'fee simple' lands (see Miller, 2009).

${ }^{122}$ According to 2005 statistics, indigenous people make up approximately 20 percent of the Canadian prison population, while only 3 percent of the general population. $R$. v. Gladue (1999) recognized this dramatic over-representation and suggested that courts pay particular attention to the cultural circumstances of offences and offenders when deciding on a prison sentence for indigenous people. Despite recognition in Gladue, recent data on Canadian prison populations indicates no significant change to these patterns (see Silver, 2007; Sinha and Landry, 2008).

${ }^{123}$ Racial dimensions to conflicts between police and indigenous peoples have been especially clear in cases of deaths in custody. Commissions into the deaths of Neil Stonechild, John Joseph Harper, and Dudley George have all spoken at-length on the issue of structural racism in policing services. At the time of this writing, several families are demanding inquiries into the deaths of indigenous men at the hands of police. This includes the cases of John Simon, Frank Paul, and Raymond Silverfox.
} 
of the settler state. The most prominent tropes of Canadian "normality" are notions of Canada as a moderate, liberal and benevolent nation (Day, 2000; Razack, 2004). These are rooted in a colonial outlook of European settlement that is deeply entrenched in contemporary imaginings of the Canadian identity. Nostalgia about the 1885 Rebellion is still a fertile ground for the promotion of Canadian nationalist tropes. For example, in August, 2010, the Canadian government celebrated the $125^{\text {th }}$ Anniversary of the Rebellion with a full-scale re-enactment of the "siege" of Fort Battleford. Hosted by Parks Canada in Battleford, Saskatchewan, the "celebration" was, predictably, from the vantage point of the NWMP and settler society.

The "siege" of Battleford refers to a three week period during the Rebellion when over 500 settlers from the Battleford vicinity crowded into the NWMP fort fearing an attack by Indian groups, particularly those under the leadership of Poundmaker. However, during this time, Fort Battleford was never attacked or surrounded, nor was its surrender demanded. As mentioned in Chapter Two, NWMP undercover operative Peter Ballendine was among those within the Fort Battleford. During the "siege" Ballendine met with Poundmaker and was assured that he held no intention to attack the Fort or break treaty commitments. Poundmaker underlined that his people were starving and felt (correctly) that they were, in fact, the victims of government aggression (see Stonechild and Maiser, 1997). Despite knowing Poundmaker's intentions, Ballendine did not relay or mention these statements to the NWMP or the townspeople within the Fort. Instead, Ballendine allowed panic to intensify and spiral into a delirium that simmered with anger and vengeance (Stonechild and Maiser, 1997:180). Evidenced by the Parks Canada reenactment, the unnecessary and unreasonable fears of settlers have become the leading 
narrative regarding the "siege," despite voluminous scholarship that details a far more complex version of events. ${ }^{124}$

Parks Canada advertised the re-enactment of the "siege" complete with pictures of soldiers aiming rifles and cannons and blurbs reading: "Follow townsfolk and settlers as they seek shelter in the Mounted Police fort to wait out the Siege of Battleford."125 The event caused a number of comments, letters to the editors, and discussions within Saskatchewan and Albertan newspapers. This also included criticisms from the descendents of Poundmaker. ${ }^{126}$

In response to public criticisms, Scott Whiting, the director of Fort Battleford National Historic Site, was forced to publicly state a "siege" was not an accurate description of what happened. However, in a series of letters sent to news outlets, Whiting responded that the re-enactment was based directly on first-person records in journals, correspondence, memoirs and reports. ${ }^{127}$ He defended the exhibition by saying that Parks Canada was displaying events based on the feelings of settlers, adding: "There was a siege mentality. That's what we're representing." ${ }^{128}$ Despite late efforts to placate critics, Parks Canada felt compelled to frame the 2010 re-enactment around the mentality of settlers. $^{129}$

The re-enactment of the "siege" of Battleford speaks to the "frontier complex"

\footnotetext{
${ }^{124}$ In particular, see Stonechild and Maiser, 1997.

${ }^{125}$ Weber, Bob (2010). 'Cree win war of words over 'siege' of Fort Battleford,' Canadian Press, October 21.

${ }^{126}$ MacLean, Rory (2010a). "Battleford 'Siege' Story Angers Poundmaker's Descendant," Edmonton Journal, Aug 16, A6.

${ }^{127}$ Whiting, Scott (2010). "Balanced Portrayal," Edmonton Journal, Aug 20, A17.

${ }^{128}$ Weber, Bob (2010). "125 $5^{\text {th }}$ Anniversary of Northwest Rebellion Brings Mock Battles, Reconciliation," Canadian Press, July 23. Emphasis added.

${ }^{129}$ In October, 2010, Parks Canada announced that they would drop the word "siege" from future reenactments. They also pledged to "work with our aboriginal counterparts and make sure their voice is included." See MacLean, Rory (2010b). "First Nations Win Battle over 'Siege' Re-enactment," Saskatoon Star-Phoenix, Oct 25, A1).
} 
that Elizabeth Furniss (1999) details in her work The Burden of History. Furniss (1999:12) demonstrates that the cultures of modern Western societies, and settler cultures in particular, "continue to be profoundly influenced by the ideological legacy and the ongoing practices of colonialism." Detailing contemporary culture in Western Canada, she argues that "there has been no radical break with the past: Canadian culture remains resolutely colonial in shape, content meaning, and practice" (ibid). Demonstrative of Canada's selective historical tradition, representations such as the "siege" of Battleford normalize the perceptions and mentalities of settler society. In addition, while these representations normalize the culture of settler society, they also circulate myths of indigenous peoples as defeated, unruly, and/or helpless.

The re-enactment of the "siege" of Fort Battleford is only one example of how indigeneity is represented as abnormal and/or inferior. ${ }^{130}$ Events such as these serve to normalize legal, political and cultural discourses designed to serve "an agenda of silent surrender to an inherently unjust relation at the root of the colonial state itself" (Alfred and Corntassel, 2005). Normalizing these marks of abnormality justifies continued interventions formed from the standards established by white, settler, liberal society. As a process, this ensures that assimilation remains the dominant project of settler colonialism.

The norms of settler colonialism are most clearly expressed in contemporary struggles over land. Land conflicts reveal how assertions of indigeneity continue to be marked as a danger to the health and prosperity of the aggregate population. This relates specifically to efforts by indigenous groups to assert their rights of self-determination to control land or resource development on their territories. ${ }^{131}$ These conflicts demonstrate

\footnotetext{
${ }^{130}$ See Francis, 1992; Furniss, 1999.

131 In the Canadian context, the terminology surrounding "self-determination" and "self-government" has
} 
how the ordering process of frontier justice continues to isolate particular threats. In the past two years, indigenous leaders from Kitchenuhmaykoosib Inninuwug, Ardoch Algonquin, and Barriere Lake First Nations, have all been disposed and/or criminalized by the Department of Indian Affairs and Canadian policing services. ${ }^{132}$ These recent efforts mirror past cases where the Canadian government has disposed chiefs that remain uncompromisingly opposed to the unfettered access and exploitation of their resources. ${ }^{133}$

The commonality between contemporary movements and those examined in this thesis is that they explicitly threaten the legality of Canadian jurisdiction and, in some cases, the legitimacy of Canadian sovereignty. Cases in Kitchenuhmaykoosib Inninuwug, Ardoch, and Barriere Lake challenge the legal regime that invites corporations to extract resources from their territories. Along with other struggles - in Six Nations, Akwesasne, Kanesatake, and elsewhere - these indigenous movements also assert their claim to selfdetermination and sovereignty. Challenges to Canadian-administered economic development and the legal regime of sovereignty such as these rekindle anxieties about national "prosperity" and reveal many of the intellectually and morally dubious claims that have legitimized much of the land theft in Canadian history.

However, as NWMP commander Crozier wrote after the Craig Incident, Canadian

\footnotetext{
been quite contentious. The Canadian state prefers to use the term "self-government" and, at no time, has it ever used "self-determination." It should be noted that indigenous movements use, almost exclusively, the term "self-determination" because of its connection with global movements challenging colonial domination. While the term "self-determination" represents an important symbolic connection with principles of de-colonization and autonomy, "self-government" is associated with "neo-colonial" government strategies (Alfred and Corntassel, 2005). Though some authors (Dalton, 2006) have argued the two terms, within the Canadian context, should be used co-terminously, indigenous scholars have critiqued "self-government" program as merely symbolic re-organizations of structures of domination (Alfred, 2005). Nonetheless, because of the Canadian government's use of "self-government" it is impossible to avoid its usage. Doing so, however, should be done while recognizing its distinction to self-determination and with the tacit acknowledgement that the Canadian state has the power to frame discursive struggles towards its own advantage.

${ }^{132}$ On the conflict in Barriere Lake First Nation and the conflict over the stalled 1990 Trilateral Agreement, see Pasternak, 2009. See Sherman (2008) on the struggle by Ardoch and Sharbot Lake Algonquin.

${ }^{133}$ See Satzewich and Mahood (1994) in particular.
} 
authorities were hard pressed to "get rid of the Indian and all troublesome questions in connection with them." Still, 125 years following the Rebellion, these conflicts arise continuously and perpetuate processes of frontier justice. In their most severe application, invocations of legal complexes result in techniques of sovereign power that criminalize opponents to Canadian economic or political designs. In cases that do not exhibit direct processes of criminalization, frontier justice imposes a "new authoritative game" that is entirely designed by Euro-Canadian legal frameworks. Instead of "ordering up the troops" - as Commander Crozier put it (Ch2) - Canadian authorities order up the lawyers. Resulting cases, petitions, and claims, gradually bleed indigenous groups and nations of resources and patience. ${ }^{134}$ When land contestations do not result in outward conflicts - as they have recently in Oka, Gustafsen Lake, Ipperwash, Caledonia - they result instead in protracted land battles. $^{135}$

Struggles over land reveal Canada's dubious claims of ownership and reminds newcomers of the colonial legacies that order these territories. Revisiting archive material surrounding the Rebellion expresses many of the rationalities and practices that animate these historical and contemporary processes of ordering. Detailing frontier justice can illustrate the continuity in the treatment of indigeneity as a form of abnormality, at-odds

134 The land claims process serves as an ideal example. The residential school settlement is another prominent and well-documented claim that took over 2 decades to resolve and, in the end, the legal process was circumvented by a politically-negotiated settlement.

${ }^{135}$ It should be noted that most often it is agents of Canadian governments who initiate violence at land contestations. This was particularly evident at Ipperwash (see Edwards, 2001). It should also be noted that some groups and nations have pursued actions outside (or in concert) with claims within the Canadian-legal framework. For example, members of the community of Grassy Narrows have maintained the longest blockade in Canadian history in an attempt to halt resource and forestry exploitation. Despite widespread criminalization, the blockade has been maintained since 2002. In an attempt to assert sovereignty, the Lubicon Lake First Nation has by-passed Canadian government and petitioned directly to the United Nations to intervene and demand that the Canadian government respect their land rights. Since the early 1990s, these calls have been ignored. This tactic mirrors efforts by Six Nations leader Deskaheh to appeal to the League of Nations in the early 1920s. Despite his attempts, Deskaheh (aka Levi General) was disposed by the Canadian government under Section 74 of the Indian Act (see Backhouse, 1999:1 15-121; Titley, 1986:114-117). 
with the objectives and norms of settler society. This is evident when expressions of indigenous rights or rights to self-determination are treated as threats to Canadian jurisdiction and, much like the Indian leadership during the Rebellion, are neutralized by various mechanisms of security. Detailing these colonial governmentalities demonstrates how indigeneity remains within the order and norms established by settler colonialism, and serves to underline the challenges of unsettling settler society. 


\section{Bibliography}

Archival Sources

Library and Archives Canada (LAC)

Department of Indian Affairs Records RG10

North-West Mounted Police Records RG18

\section{Books and Articles}

Abele, Frances and Michael Prince (2006). "Four Pathways̃ to Aboriginal SelfGovernment in Canada," American Review of Canadian Studies, 36: 568 - 595.

Alfred, Taiaiake (2005). Wasase: Indigenous Pathways of Action and Freedom. Peterborough, Ont.: Broadview Press.

Alfred, Taiaiake and Jeff Corntassel (2005). "Being Indigenous: Resurgences against. Contemporary Colonialism," Government and Opposition, 40: 597-614.

Allen, Robert (1983). "A Witness to Murder: The Cypress Hills Massacre and the Conflict of Attitudes towards the Native People of the Canadian and American West during the 1870s," in As Long as the Sun Shines and Waier Flows: a Reader in Canadian Native Studies. Getty, Ian and Antoine S. Lussier (eds). Vancouver: University of British Columbia Press, 229-246.

Baker, W.M. (ed) (1998). The Mounted Police and Prairie Society, 1873-1919. Regina, Canada: University of Regina, Canadian Plains Research Centre.

Backhouse, Constance (1999) Colour-Coded; a Legal History of Racism in Canada, 1900-1950. Toronto, University of Toronto Press.

Bakhle, Janaki(2010) "Savarkar (1883-1966), Sedition and Surveillance: the rule of law in a colonial situation," Social History, 35/1: 51-75.

Bartlett, Richart (1980). "Indian Act of Canada: An Unyielding Barrier," American Indian Journal, 6/4:11-26.

Barron, L. (1988). "The Indian pass system in the Canadian West, 1882-1935," Prairie Forum, 130: 25-42.

Barron, Laurie and James B. Waldram (eds) (1986). 1885 and After: Native Society in Transition. Regina : Canadian Plains Research Center, University of Regina.

Bauman, Zygmunt (2002). "Reconnaissance Wars of the Planetary Frontierland," in Theory, Culture \& Society, 19/4: 81-90.

Beahen, William and Stan Horrall (1998). Red Coats on the Prairies: The North-West 
Mounted Police, 1886-1900. Regina, Sask.: Centax Books, PrintWest Pub. Services.

Beal, Bob and Rod Macleod (1984). Prairie Fire: The 1885 North-West Rebellion. Edmonton: Hurtig.

Beal, Bob and Barry Wright (2009). "Summary and Incompetent Justice: Legal Responses to the 1885 Crisis," in Canadian State Trials Volume III: Political Trials and Security Measures, 1840-1914, Wright, Barry and Susan Binnie (eds). Toronto: University of Toronto Press, 353-410.

Bhabha, Homi (1994). The Location of Culture. London: Routledge.

Bingaman, Sandra Estlin (1975). "The Trials of Poundmaker and Big Bear, 1885," Saskatchewan History, 28/3:81-102.

Blomley, Nicholas (2003). "Law, Property, and the Spaces of Violence: The Frontier, the Survey, and the Grid," Annals, Association of American Geographers, 93/1: 121-141.

Brockling, Ulrich, Susanne Krasrnann and Thomas Lemke (eds) (2011). Governmentality: Current Issues and Future Challenges. New York: Routledge.

Brown, Dee (1970). Bury my Heart at Wounded Knee; an Indian history of the American West. New York: Holt, Rinehart \& Winston.

Brown, Robert Craig (1964). Canada's National Policy, 1883-1900: A Study in Canadian-American Relations. Princeton: Princeton University Press.

Borrows, John (1999). "Sovereignty's Alchemy: an Analysis of Delgamuukw V. British Columbia," Osgoode Hall Law Journal, 37/ 3, 538 - 594.

Buckley, Helen (1992). From Wooden Ploughs to Welfare: Why Indian Policy Failed in the Prairie Provinces. Montreal: McGill-Queens University Press.

Carter, Sarah (1990). Lost Harvests : Prairie Indian Reserve Farmers and Government Policy. Montreal: McGill-Queen's University Press.

Castel, Robert (1991). "From Dangerousness to Risk," in Fhe Foucault Effect: Studies in Governmentality. Graham Burchell, Colin Gordon, and Peter Miller (Eds). Chicago: University of Chicago Press, 281-298.

Churchill, Ward (1997). A Little Matter of Genocide: Holocaust and Denial in the Americas, 1492 to the Present. San Francisco: City Lights Books.

Coates, K. (1999). "The 'Gentle' Occupation: The Settlement of Canada and the Dispossession of the First Nations," in Indigenous Peoples Rights in Australia, Canada and New Zealand, Havemann, P (Ed.). Oxford, UK: Oxford University Press, 141-161. 
Comaroff, Jean, and John L. Comaroff (1991). "Of Revelation and Revolution," in Christianity, Colonialism, and Consciousness in South Africa (Vol. 1). Chicago: University of Chicago Press.

Comaroff, John (2001). "Colonialism, Culture and the Law: A foreword," in Law and Social Inquiry 26/2: 305-14.

Creighton, Donald (1988). John A. Macdonald. Toronto: University of Toronto Press.

Cross, Michael S. (1970). The Frontier Thesis and the Canadas: The Debate on the Impact of the Canadian Environment. Toronto: Copp Clark.

Dalton, Jennifer E (2006). “Aboriginal Self-Determination in Canada: Protections Afforded by the Judiciary and Government," Canadian Journal of Law and Society / Revue Canadienne Droit et Société, 21/1: 11-37.

Day, Richard J. F. (2000). Multiculturalism and the History of Canadian Diversity. Toronto: University of Toronto Press.

Dean, Mitchell (2002). "Powers of Life and Death Beyond Governmentality," Journal for Cultural Research, 6/1: 119-138.

Delgamuukw v. British Columbia, 3 S.C.R. 1010 (S.C.C.), 1997.

Dempsey, H.A. (1998). "The Wild Ones," in The Mounted Police and Prairie Society, 1873-1919, Baker, W.M. (Ed.), Regina, Canada: University of Regina, Canadian Plains Research Centre, 71-84.

Dutton, Michael (2010). "The paradoxical after-life of colonial governmentality," Social Identities, 16/5, 635-649.

Dyke, Noel (1986). "An Opportunity Lost: The Initiative of the Reserve Agricultural Programme in the Prairie West," in 1885 and After: Native Society in Transition. Barron, Laurie and James Waldram (eds). Regina: Canadian Plains Research Center, University of Regina, 121-138.

Edwards, Peter (2001). One Dead Indian: The Premier, the Police, and the Ipperwash Crisis. Toronto : Stoddart.

Erdoes, Richard (1972). The Sun Dance People: The Plains Indians, Their Past and Present. New York: Knopf.

Ferguson, Kathy (1993). The Man Question: Visions of Subjectivity in Feminist Theory. Berkeley: University of California Press. 
Flanagan, Thomas (2000). First Nations? Second Thoughts. Montreal: McGill-Queen's University Press.

Flanagan, Tom, Christopher Alcantara and André Le Dressay (2010). Beyond the Indian Act: Restoring Aboriginal Property Rights. Montréal: McGill-Queen's University Press.

Fisher, Robin (1977). Contact and Conflict : Indian-european Relations in British Columbia, 1774-1890. Vancouver : University of British Columbia Press.

Ford, Lisa (2010) Settler Sovereignty: Jurisdiction and Indigenous People in America and Australia, 1788-1836. Cambridge, Mass.: Harvard University Press.

Foucault, Michel (1984). The Foucault Reader. Paul Rabinow (ed). New York: Pantheon Books.

Foucault, Michael (1991a). "Governmentality," in The Foucault Effect: Studies in Governmentality. Graham, Burchell, Colin Gordon, and Peter Miller (eds). Chicago: University of Chicago Press, 87-104.

Foucault, Michael (1991b). "Questions of Method," in The Foucault Effect: Studies in Governmentality. Burchell, Graham, Colin Gordon, and Peter Miller (eds). Chicago: University of Chicago Press, 73-86.

Foucault, Michel (2003). 'Society Must Be Defended', Lectures at the College de France 1975-1976. New York: Picador.

Foucault, Michel, (2003b). Abnormal: Lectures at the College de France, 1974. New York: Picador.

Foucault, Michel (2007). Security, Territory Population: Lectures at the College de France. New York: Picador.

Foucault, Michel (2008). The Birth of Biopolitics: Lectures at the College de France. New York: Picador.

Francis, Daniel (1992). The Imaginary Indian: The Image of the Indian in Canadian Culture. Vancouver: Arsenal Pulp Press.

Francis, Daniel (1997). National Dreams: Myth, Memory, and Canadian History. Vancouver: Arsenal Pulp Press.

Friedner, Michele (2010). "Biopower, Biosociality, and Community Formation: How Biopower is Constitutive of the Deaf Community," Sign Language Studies, 10/3: 336347.

Furniss, Elizabeth (1999). The Burden of History: Colonialism and the Frontier Myth in 
a Rural Canadian Community. Vancouver: UBC Press.

Gerein, Keith (2011). "Canadian Police Fill the Bill; Dozens of Officers Training Afghan Counterparts," Edmonton Journal, April 1, A3.

Getty, Ian and Antoine Lussier (eds) (1983). As Long as the Sun Shines and Water Flows: a Reader in Canadian Native Studies. Vancouver: University of British Columbia Press.

Ghere, David L. and Alvin Morrison (2001). "Searching for Justice on the Maine Frontier: Legal Concepts, Treaties and the 1749 Wiscasset Incident," American Indian Quarterly, 25/3:378 -399.

Goldberg, David Theo (2002). The Racial State. Malden, Mass: Blackwell Publishers.

Gordon, Colin (1991). "Governmental Rationality: An Introduction," in Foucault, Michael (1991). The Foucault Effect: Studies in Governmentality. (Eds) Graham Burchell, Colin Gordon, and Peter Miller. Chicago : University of Chicago Press, 1-52.

Graybill, Andrew (2007). Policing the Great Plains: Rangers, Mounties, and the North American Frontier, 1875-1910. Lincoln: University of Nebraska Press

Green, Joyce A (1995). “Towards a Detente with History: Confronting Canada's Colonial Legacy," International Journal of Canadian Studies, 12:85-105.

Hacking, Ian (1995). "The Looping Effect of Human Kinds" in Causal Cognition: A Multidisciplinary Debate. Sperber, Dan and David Premack, and Ann James Premack (eds). New York: Oxford University Press, 351-383.

Hall, Anthony (2003). American Empire and the Fourth World. Montreal: McGillQueen's University Press.

Hannah, Matthew (2000). Governmentality and the Mastery of Territory in Nineteenthcentury America. Cambridge: Cambridge University Press.

Harding, Robert (2006). "Historical Representations of Aboriginal People in the Canadian News Media," Discourse \& Society, 17/2: 205-235.

Harring, Sidney (1998). White Man's Law: Native People in Nineteenth-century Canadian Jurisprudence. Toronto: University of Toronto Press.

Harring, Sidney (2005). “"There Seemed to be no Recognized Law': Canadian Law and the Prairie First Nations," in Laws and Societies in the Canadian Prairie West, 16701940, Knafla, Louis and Jonathan Swainger (Eds). Vancouver: UBC Press, 57-91.

Harris, R. Cole (1997). The Resettlement of British Columbia; Essays on Colonialism and Geographical Change. Vancouver, UBC Press. 
Haydon, Arthur Lincoln (1911). The Riders of the Plains: Adventures and Romance with the North-West Mounted Police, 1873-1910. Toronto: Copp, Clark.

Hill, Douglas (1967). The Opening of the Canadian West: Where Strong Men Gathered. New York: John Day.

Hindess, Barry (2001). "Not at Home in the Empire," Social Identities, 7/3: 363-377.

Hubner, B. (1998). "Horse Stealing and the Borderline: The NWMP and the Control of Indian Movement, 1874-1900," in The Mounted Police and Prairie Society, 1873-1919, Baker, W.M. (Ed.), Regina, Canada: University of Regina, Canadian Plains Research Centre, 53-70.

Hussain, Nasser (2003). Jurisprudence of Emergency: Colonialism and the Rule of Law. Ann Arbor : University of Michigan Press.

Ibrahim, Abdullahi Ali (1997). "Tale of Two Sudanese Courts: Colonial Governmentality Revisited," African Studies Review, 40/1:13-33.

Inda, Xavier (2005). "Analytics of the Modern: An Introduction," in Anthropologies of Modernity: Foucault, Governmentality, and Life Politics. Inda, Xavier (ed). Malden, MA, USA: Blackwell Publishing, 1-22.

Jennings, John (1986). "The North West Mounted Police and Indian Policy after the 1885 Rebellion," in 1885 and After: Native Society in Transition. Barron, Laurie and James B. Waldram (eds). Regina: Canadian Plains Research Center, University of Regina, 225-240.

Kalpagam, U. (2000). "Colonial Governmentality and the "Economy," Economy and Society, 29/3: 418-438.

Kalpagam, U. (2002). "Colonial Governmentality and the Public Sphere in India," Journal of Historical Sociology, 15/1: 35-58.

Kempa, Michael (2010). "Academic Engagement of International Policing-Reform Assistance: Putting Foucauldian Genealogy to Practical Use," Canadian Journal of Criminology and Criminal Justice, 52/3: 271-283.

Kingseed, Wyatt (2002). "Teddy Roosevelt's Frontier Justice," American History, 36: 2228.

Knafla, Louis (2005). "Introduction: Laws and Societies in the Anglo-Canadian NorthWest Frontier and Prairie Provinces, 1670-1940" in Laws and Societies in the Canadian Prairie West, 1670-1940, Knafla, Louis and Jonathan Swainger (eds). Vancouver: UBC Press, 1-56. 
Knafla, Louis and Jonathan Swainger (eds) (2005). Laws and Societies in the Canadian Prairie West, 1670-1940. Vancouver: UBC Press, 1-56.

Knuckle, Robert (1994). In the Line of Duty: The Honour Roll of the RCMP since 1873. General Store Publishing House.

Kobayashi, A. (1995). "Challenging the National Dream: Gender Persecution and Canadian Immigration Law," in Nationalism, Racism and the Rule of Law, Fitzpatrick, Peter (ed). Aldershot: Dartmouth Publishing Company, 61-73.

Ladner, Keira L (2001). "Negotiated Inferiority: The Royal Commission on Aboriginal People's Vision of a Renewed Relationship", The American Review of Canadian Studies (Spring/Summer 2001): 241-264.

Legg, Stephen (2005). "Foucault's Population Geographies: Classifications, Biopolitics and Governmental Spaces," Population, Space and Place, 11: 137-156.

Leighton, Douglas (1983). "A Victorian Civil Servant at Work: Lawrence Vankoughnet and the Canadian Indian Department, 1874-1893," in As Long as the Sun Shines and Water Flows: a Reader in Canadian Native Studies. Getty, Ian and Antoine Lussier (eds).Vancouver: University of British Columbia Press, 104-119.

Lianos, Michalis and Mary Douglas (2000). "Dangerization and the End of Deviance," British Journal of Criminology, 40: 261-278.

Lyons, David (2009). "Identification Practices: State Formation, Crime Control, Colonialism and War," in Technologies of inSecurity: The Surveillance of Everyday Life. Aas, Katja Franko and Helene Oppen Gundhus and Heidi Mork Lomell (eds). New York: Routledge-Cavendish, 42-58.

Mackey, Eva (2002). The House of Difference: Cultural Politics and National Identity in Canada. Toronto: University of Toronto Press.

Macklem, Patrick (1993). "Ethnonationalism, Aboriginal Identities, and the Law," in Ethnicity and Aboriginality: Case Studies in Ethnonationalism. Levin, Michael (ed), Toronto: University of Toronto Press.

Macleod, R. C. (1976). The North-West Mounted Police and Law Enforcement, 1873 1905. Toronto: University of Toronto Press.

Macleod, R. C. (1998). The North West Mounted Police, 1873-1919. Ottawa: Canadian Historical Association.

Marx, Gary (1988). Under Cover: Police Surveillance in America (Los Angeles: University of California Press. 
Mavromichalis, Anna-Maria (1998). "Tar and Feathers: The Mounted Police and Frontier Justice," in The Mounted Police and Prairie Society, 1873-1919, Baker, W.M. (Ed.), Regina, Canada: University of Regina, Canadian Plains Research Centre, 109-118.

Mawani, Renisa (2005). "Genealogies of the Land: Aboriginality, Law, and Territory in Vancouver’s Stanley Park," Social \& Legal Studies, 14/3: 315-339.

Mawani, Renisa (2007). "Legalities of Nature: Law, Empire, and Wilderness Landscapes in Canada," Social Identities, 13/6: 715-734.

Mawani, Renisa. (2009). Colonial Proximities: Crossracial Encounters and Juridical Truths in British Columbia, 1871-1921. Vancouver: UBC Press.

McNab, David T. (1983). "Herman Merivale and Colonial Office Indian Policy in the Mid-Nineteenth Century," in As Long as the Sun Shines and Water Flows: a Reader in Canadian Native Studies. Getty, Ian and Antoine Lussier (eds).Vancouver: University of British Columbia Press, 85-103.

McWhorter, Ladelle (2009). Racism and Sexual Oppression in Anglo-America: A Genealogy. Bloomington: Indiana University Press.

Mika, Nick and Helma (1972). The Riel Rebellion 1885. Belleville: Mika Silk Screening Ltd.

Miller, Bruce Granville (2006). Who Are Indigenes? A Comparative Study of Canadian and American Practices," American Behavioral Scientist, 50(4):462-458.

Miller, J.R. (1989). Skyscrapers Hide the Heavens: A History of Indian-White Relations in Canada (Revised edition). Toronto: University of Toronto Press.

Miller, J.R. (2009). Compact, Contract, Covenant: Aboriginal Treaty-Making in Canada. Toronto: University of Toronto Press.

Miller, Robert (2006). Native America, Discovered and Conquered: Thomas Jefferson, Lewis \& Clark, and Manifest Destiny. Westport, Conn: Praeger Publishers.

Milloy, Jonathan (1991). "The Early Indian Acts: Developmental Strategy and Constitutional Change," in Sweet Promises: a Reader on Indian-White Relations in Canada. Miller, J.R. (ed). Toronto: University of Toronto Press, 145-156.

Monture-Angus, Patricia (1999). Journeying Forward: Dreaming First Nations' Independence. Halifax: Fernwood.

Moreton-Robinson, Aileen. "Towards a New Research Agenda? Foucault, Whiteness and Indigenous Sovereignty," Journal of Sociology, 42/4: 383-395. 
Morris, Alexander, (1971[1880]). The Treaties of Canada with the Indians of Manitoba and the North West Territories. Toronto: Coles Publishing.

Morrison, William R. (1985). Showing the Flag: The Mounted Police and Canadian Sovereignty in the North, 1894-1925. Vancouver: University of British Columbia Press.

Nettelbeck, Amanda and Russell Smandych (2010). "Policing Indigenous Peoples on Two Colonial Frontiers: Australia's Mounted Police and Canada's North-West Mounted Police," The Australian and New Zealand Journal of Criminology, 43/2:356-375.

Nigol, Paul C (2005). "Discipline and Discretion in the Mid-Eighteenth-Century Hudson's Bay Company Private Justice System," in Laws and Societies in the Canadian Prairie West, 1670-1940, Knafla, Louis and Jonathan Swainger (eds). Vancouver: UBC Press, 150-184.

NWMP (1973[1889]). Commissioners of the Royal North-West Mounted Police Force (1888-1889). The New West: Being the Official Reports to Parliament of the Activities of the Royal North-West Mounted Police Force from 1888-1889. Queen's Printer: Ottawa. Facsimile edition published by Coles Publishing Company, Toronto.

Obadele-Starks, Ernest (2007). Freebooters and Smugglers: The Foreign Slave Trade in the United States after 1808. Fayetteville : University of Arkansas Press, 2007.

Oliver, Edmund Henry (1915). Canadian North-West, its Early Development and Legislative Records. Ottawa: Government Printing Office, 1914-1915.

Opitz, Sven (2011). "Government Unlimited: The Security Dispositif of Illiberal Governmentality," in Governmentality: Current Issues and Future Challenges. Brockling, Ulrich, Susanne Krasrnann and Thomas Lemke (eds). New York: Routledge, 93-114.

Pasquino, Pasquale (1991). "Theatrum Politicum: The Geneology of Capital - Police and the State of Prosperity," in The Foucault Effect: Studies in Governmentality. Graham Burchell, Colin Gordon, and Peter Miller (eds). Chicago: University of Chicago Press, 105-119.

Pasternak, Shiri 2009. "They're Clear Cutting Our Way of Life: Algonquin's Defend the Forest," Upping the Anti, 8:125-144.

Paul, Daniel N (2006). We Are Not the Savages (third edition). Halifax: Fernwood Publishing.

Pettipas, Katherine (1994). Severing the Ties that Bind: Government Repression of Indigenous Religion Ceremonies on the Prairies. Winnipeg: University of Manitoba Press.

Prieto, Mercedes (2003). A Liberalism of Fear: Imagining Indigenous Subjects in 
Postcolonial Ecuador, 1895-1950. Unpublished PhD Thesis: University of Florida.

Prasad, Ajnesh (2009). "Contesting Hegemony through Genealogy: Foucault and Cross Cultural," International Journal of Cross Cultural Management, 9: 359-369.

R. v. Gladue, (1999). 1 S.C.R. 688.

Razack, Sherene (2004). Dark Threats and White Knights: the Somalia Affair, Peacekeeping and the New Imperialism. Toronto: University of Toronto Press.

RCAP (1996). Report of the Royal Commission of Aboriginal Peoples. 2 Vols. Ottawa: Canada Communications Group.

Roberts, Tony (2005). Frontier Justice: A History of the Gulf Country to 1900. Brisbane, Australia: University of Queensland Press.

Roe, Frank Gilbert, (1970) The North American Buffalo: A Critical Study of the Species in its Wild State. Toronto: University of Toronto Press.

Rose, Nikolas and Mariana Valverde (1998). "Governed By Law," Social Legal Studies, (7): 541-551.

Rose, Nikolas and Pat O’Malley, Mariana Valverde (2006). "Governmentality," Annual Review Law Social Science, 2:83-104.

Rullac, Stephane (2010). "The Homeless and Homelessness: A Very Political Social Issue," in Nouvelles Pratiques Sociales, 22/2: 193-198.

Russell, P. (1979). “The National Policy, 1879-1979," Journal of Canadian Studies, 14.

Sarat, Austin and Thomas R. Kearns (1992). Law's Violence. Ann Arbor: University of Michigan Press.

Satzewich, Vic, and L. Mahood (1994). "Indian Affairs and Band Governance: Deposing Indian Chiefs in Western Canada, 1896-1911," Canadian Ethnic Studies, 26: 40-58.

Scott, David (1995). "Colonial Governmentality," Social Text, No. 43: 191-220.

Scott, David (1999). Refashioning Futures: Criticism after Postcoloniality. Princeton: Princeton University Press.

Scott, David (2005). "Colonial Governmentality," in Anthropologies of Modernity: Foucault, Governmentality, and Life Politics. Inda, Xavier (ed). Malden, MA, USA: Blackwell Publishing, 23-51.

Sherman, Paula (2008). Dishonour of the Crown: The Ontario Resource Regime in the 
Valley of the Kiji Sibi. Winnipeg: Arbiter Ring Press.

Shewell, Hugh (2005). 'Enough to Keep Them Alive': Indian Welfare in Canada, 18731965. Toronto: University of Toronto Press.

Silver, A.I. and Marie-France Valleur (1967) The North-West Rebellion. Toronto: Copp Clark.

Silver, Warren (2007). "Crime statistics in Canada, 2006." Juristat, 27/5. Statistics Canada Catalogue no. 85-002. Ottawa.

Sinha, Maire and Landry, Laura (2008). "Adult Correctional Services in Canada, 2005/2006." Juristat, 28/6. Statistics Canada Catalogue no. 85-002. Ottawa.

Slotkin, Richard (1992). Gunfighter Nation: the Myth of the Frontier in Twentiethcentury America. Toronto: Maxwell Macmillan Canada.

Smith, D. (1993). "The Emergence of 'Eskimo Status': An Examination of the Eskimo Disk List System and its Social Consequences, 1925-1970," in Anthropology, Public Policy, and Native Peoples in Canada. Dyck, N. and J.B. Waldram (eds). Montreal: McGill-Queens University Press, 41-74.

Spry, Irene M. (1983). "The Tragedy of the Loss of the Commons in Western Canada," in As Long as the Sun Shines and Water Flows: a Reader in Canadian Native Studies. Getty, Ian and Antoine Lussier (eds).Vancouver: University of British Columbia Press, 203-228.

Stewart, Robert (1999 [1979]). Sam Steel: Lion of the Frontier. Regina: Centax Books/Publishing Solutions, PrintWest Group.

Stoler, Ann Laura (1995). Race and the Education of Desire. Durham : Duke University Press.

Stoler, Ann Laura (2002). Carnal Knowledge and Imperial Power: Race and the Intimate in Colonial Rule. Berkeley: University of California Press.

Stoler, Ann Laura (2008). "Epistemic Politics: Ontologies of Colonial Common Sense," The Philosophical Forum, 39/3: 349-361.

Stoler, Ann Laura (2009). Along the Archival Grain: Epistemic Anxieties and Colonial Common Sense. Princeton: Princeton University Press.

Stonechild, Blair and Bill Maiser (1997). Loyal Till Death: Indians and the North-West Rebellion. Calgary: Fifth House.

Sommer, Doris (1991). Foundational Fictions: The National Romances of Latin America. Berkley: University of California Press. 
Surtees, Robert (1969). "The Development of an Indian Reserve Policy in Canada," in Ontario History, 61:87-98.

Taylor, John L. (1977) "Canada's North-West Indian Policy in the 1870s: Traditional Premises and Necessary Innovations," in Approaches to Native History in Canada:

Papers of a Conference held at National Museum of Man, October, 1975. D.A. Muise (ed). Ottawa: National Museums of Canada, History Division Paper No. 25: 104-111.

Terranova, Tiziana (2009). "Another Life: The Nature of Political Economy in Foucault's Genealogy of Biopolitics," Theory, Culture \& Society, 26/6: 234-262.

Titley, E. Brian (1986). A Narrow Vision: Duncan Campbell Scott and the Administration of Indian Affairs in Canada. Vancouver: University of British Columbia Press.

Titley, E. Brian (1999). The Frontier World of Edgar Dewdney. Vancouver: UBC Press.

Titley, E. Brian (2009).The Indian Commissioners: Agents of the State and Indian Policy in Canada's Prairie West, 1873-1932. Edmonton: University of Alberta Press.

Tobias, John (1977). "Indian Reserves in Western Canada: Indian Homelands or Devises for Assimilation," in Approaches to Native History in Canada: Papers of a Conference held at National Museum of Man, October, 1975. D.A. Muise (Ed.). Ottawa: National Museums of Canada, History Division Paper No. 25: 104-111.

Tobias, John (1983). "Canada's Subjugation of the Plains Cree, 1879-1885," in Canadian Historical Review, 64/4: 519-48.

Tough, Frank J. (1992 ). "Aboriginal Rights versus the Deed of Surrender: The Legal Rights of Native Peoples and Canada's Acquisition of the Hudson's Bay Company Territory," Prairie Forum, 7/2:225-250.

Tully, James (1995). Strange Multiplicity: Constitutionalism in an Age of Diversity. Cambridge: Cambridge University Press.

Turner, John Peter (1950). North-West Mounted Police; 1873-1893.Ottawa: King's Printer.

Venn, Couze (2009). "Neoliberal Political Economy, Biopolitics and Colonialism: A Transcolonial Genealogy of Inequality," Theory, Culture \& Society, 26/6: 206-233.

Walden, K. (1982). Visions of Order: The Canadian Mounties in Symbol and Myth. Toronto, Canada: Butterworth.

Wallace, Jim (1998). A Trying Time: The North-West Mounted Police in the 1885 
Rebellion. Winnipeg: Bunker to Bunker Books.

Walters, Mark (1996). "The Extension of Colonial Criminal Jurisdiction over the Aboriginal Peoples of Upper Canada: Reconsidering the Shawanakiskie Case (1822-26)," The University of Toronto Law Journal, 46/2: 273-310.

West, Mark \& Chris Carey (2006). "(Re)Enacting Frontier Justice: The Bush Administration's Tactical Narration of the Old West Fantasy after September 11," Quarterly Journal of Speech, 924:379-412.

Williams, Robert (1990). The American Indian in Western Legal Thought: The Discourses of Conquest. New York: Oxford University Press.

Wolf, Eric (1997). Europe and the People Without History. Berkeley, University of California Press. 